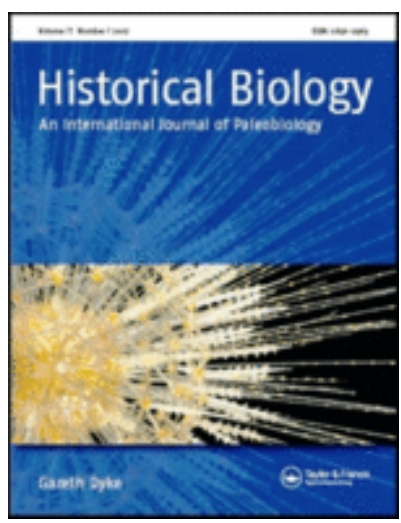

\title{
The Libycosaurus (Hippopotamoidea, Artiodactyla) intercontinental dispersal event at the early Late Miocene revealed by new fossil remains from Kasserine area, Tunisia
}

\begin{tabular}{|r|l|}
\hline Journal: & Historical Biology \\
\hline Manuscript ID & GHBI-2018-0166.R2 \\
\hline Manuscript Type: & Original Article \\
\hline Author: & n/a \\
\hline Complete List of Authors: & $\begin{array}{l}\text { Lihoreau, Fabrice; Institut des sciences de l'évolution } \\
\text { Essid, El Mebrouk; Office National des Mines (ONM) } \\
\text { Hayet Khayati Ammar, Hayet ; Office National des Mines (ONM) } \\
\text { Marivaux, Laurent; Institut des sciences de l'évolution } \\
\text { Marzougui, Wissem; Office National des Mines (ONM) } \\
\text { Tabuce, Rodolphe; Institut des sciences de l'evolution, Forme } \\
\text { Temani, Rim; Office National des Mines (ONM) } \\
\text { Vianey-Liaud, Monique; Institut des sciences de l'evolution, Forme } \\
\text { Merzeraud, Gilles; Geosciences Montpellier }\end{array}$ \\
\hline Keywords: & $\begin{array}{l}\text { Cladistic analysis, Bothriodontinae, Merycopotamini, Sahara, Tortonian, } \\
\text { dispersal events }\end{array}$ \\
\hline
\end{tabular}

\section{SCHOLARONE \\ Manuscripts}




\section{The Libycosaurus (Hippopotamoidea, Artiodactyla) intercontinental dispersal event at the early Late Miocene revealed by new fossil remains from Kasserine area, Tunisia}

Fabrice Lihoreau ${ }^{\mathrm{a} *}$, El Mabrouk Essid ${ }^{\mathrm{b}}$, Hayet Khayati Ammarb ${ }^{\mathrm{b}}$ Laurent Marivaux ${ }^{\mathrm{a}}$, Wissem Marzougui ${ }^{\mathrm{b}}$, Rodolphe Tabuce ${ }^{\mathrm{a}}$, Rim Temani $^{\mathrm{b}}$, Monique Vianey-Liaud ${ }^{\mathrm{a}}$ and Gilles Merzeraud ${ }^{\mathrm{c}}$

anstitut des Sciences de l'Evolution de Montpellier, Univ. Montpellier CNRS IRD EPHE, Montpellier, France

bService Géologique, Office National des Mines, Tunis, Tunisia

${ }^{\mathrm{c} G e ́ o s c i e n c e s ~ M o n t p e l l i e r, ~ U n i v . ~ M o n t p e l l i e r ~ C N R S, ~ M o n t p e l l i e r, ~ F r a n c e ~}$

*Corresponding author: Institut des Sciences de l'Evolution de Montpellier, Université de Montpellier, cc064 place eugène Bataillon 34095 Montpellier cedex, France, Fabrice.Lihoreau@UMontpellier.fr 


\title{
The Libycosaurus (Hippopotamoidea, Artiodactyla) intercontinental dispersal event at the early Late Miocene revealed by new fossil
} remains from Kasserine area, Tunisia

\begin{abstract}
Anthracotheres dispersed from Asia toward Africa at least three times: at the Eocene/Oligocene transition, during early Miocene and later during the Miocene. Those dispersals are important datum events for African tertiary biochronology. New fossil remains of early Libycosaurus, the genus implicated in the Late Miocene dispersal, are described from a new Tunisian locality of the Kasserine area. The new fossils enhance the hypodigm of Libycosaurus algeriensis and permit increased resolution of the phylogenetic position of this species using cladistics analysis. The inclusion of the genus Libycosaurus within the welldescribed Merycopotamus lineage allows us to constrain its dispersal time. Dispersal of this anthracothere from the Indian sub-continent to Africa was probably facilitated by sea level decrease during the early Tortonian, just preceding the Hipparion dispersal event. This new age estimation refines the resolution of the succession of late Miocene deposits in the Maghreb and frames the date of the onset of the Sahara.
\end{abstract}

Keywords: Cladistic analysis, Bothriodontinae, Merycopotamini, Sahara, Tortonian, dispersal events 


\section{Introduction}

Anthracotheres are an extinct family of morphologically and ecologically diverse cetartiodactyls, usually interpreted as swampy environment inhabitants. Within the superfamily Hippopotamoidea, the anthracotheres are considered closely related to the Hippopotamidae (e.g., Boisserie et al. 2011; Lihoreau, Boisserie, et al. 2015), but parts of the branching sequence within this clade are still unclear; as such the content of some anthracothere genera requires revisions. Anthracotheres are also particularly remarkable as they display unusual dispersal abilities, leading several palaeontologists to regard them as 'ungulate pioneers' in most of the intercontinental dispersal events (e.g., Ducrocq 1995; Lihoreau and Ducrocq 2007; Holroyd et al. 2010; Grandi and Bona 2017; Scherler et al. 2018).

The last African genus of anthracotheres, Libycosaurus, engaged in a form of semi-aquatic-lifestyle as indicated by the marked specialisation of its skeleton and its paleobiology (Lihoreau et al. 2006; Lihoreau et al. 2014). During the middle-late Miocene in Africa, Libycosaurus underwent a spectacular evolution characterized by a substantial body size change and a diet shifting (increase in C4-plant consumption), associated with social modifications notably with sexual size dimorphism and indices of fight between males (Lihoreau et al. 2014). This evolution was linked to the reduction of Libycosaurus habitat through change of the river system probably due to the variation of Sahara expansion. However, the evolutionary history of the genus is incomplete, as the origin of the genus remains unclear. A recent validation of the small and plesiomorphic species Libycosaurus algeriensis Ducrocq et al. 2001, with new material from the locality of Bir el Ater 3 (Algeria), highlighted the possibility that Libycosaurus 
originated in Africa during the middle Miocene following the arrival of its ancestor from the Indian subcontinent (Lihoreau, Hautier, et al. 2015).

We recently discovered new fossils attributable to Libycosaurus algeriensis in Tunisia, from Sidi Hedri, a new locality situated near the town of Kasserine. We describe here this new fossil material, which provides previously unknown elements for documenting the basal morphotype of the genus. We perform a cladistic assessment incorporating these new data with previously known morphological evidence, in order to formalize the position of Libycosaurus within the anthracotheres. The original phylogeny discussed in this study constrains a paleobiogeographic scenario prior to the initiation of the Sahara desert and contemporaneous to a major sea-level drop. This scenario refines the age estimates of some North African vertebrate fossil-bearing deposits of the Miocene epoch.

\section{Materials and Methods}

\section{Provenance of the new fossil material}

The new material was discovered in the western part of central Tunisia, in the Kasserine region, north of the Djebel Chambi (Fig. 1). The locality yielded three specimens belonging to the same taxon, due to coherence in size and morphology. The new remains consist of a right upper canine (SHI01), a right lower mandible with $\mathrm{P} / 3-\mathrm{M} / 2$ (SHI02) and a left M/3 (SHI03). These fossils were found during our 2012 field expedition and come from a unique locality, Sidi Hedri, corresponding to a limited spot and horizon (F4 on Fig. 1). The name locality is due to its proximity to the Marabout of Sidi Hedri. The material is housed in the paleontological collections of the Museum of the Office National des Mines (ONM) in Tunis, Tunisia. 
Material for comparisons is abbreviated as follows: $\mathrm{M}$, material from the Natural History Museum, London, NG, material from Nagri Fm. Pakistan housed at the Utrecht University, Utrecht, Y, material from Potwar Plateau housed at the Harvard Peabody Museum, Cambridge, and CUWM material from Wadi Moghra housed at Cairo University, Cairo.

\section{Stratigraphical context}

The new Sidi Hedri fossil-bearing locality is situated in the Bir-Om-Ali stratigraphic section (Fig. 1; Vialle et al. 2013; Sweydan et al. 2018), north side of the Djebel Chambi. This section overlies laterally the late early to early middle Eocene fossilbearing localities of Chambi locus 1 (CBI-1) and Chambi locus 2 (CBI-2), which have yielded numerous fossil remains of key taxa documenting the early evolutionary history of several vertebrates from Africa (e.g., Marivaux et al. 2015, Ravel et al. 2016, Mourer-chauviré et al. 2016, Tabuce 2018). The section contains the late Eocene locality of Bir-Om-Ali that yielded fragmentary fossil remains of the embrithopod Arsinoitherium (Vialle et al. 2013; F2 on Fig. 1), the fossiliferous locality of Mabrouk, a level with reworked marine fossils dated from the late Eocene-early Oligocene (Sweydan et al. 2018; F3 on Fig. 1), and a Neogene fine grained sandstone corresponding to the Sidi Hedri locality (F4 on Fig. 1). The Sidi Hedri fossiliferous horizon overlies alluvial-fan conglomerates in a unit consisting of fluvio-deltaic deposits. This unit was generally considered as belonging to the Beglia Formation (Fm.) but the definition of this formation might be taken with caution (e.g., Mannaï-Tayech 2006; Mannaï-Tayech 2009; Belghithi et al. 2016). The sandstone attributed by Hartenberger et al. (2001) to the Beglia Fm. in fact corresponds to the uppermost Paleogene levels where the Mabrouk locality occurs (Sweydan et al. 2018). The 
geological study made by Hartenberger et al. (2001) did not include the area where the Neogene sediments outcrop. Furthermore, recent discussion of the Miocene sandstones capping the Nementcha Fm. in Algeria (Lihoreau, Hautier, et al. 2015), only $130 \mathrm{~km}$ southwest of Sidi Hedri, highlighted the critical role of fossil assemblage in correlating between continental formations, and demonstrates that it is best to avoid using only facies correlation for precise dating.

The Neogene deposits in Tunisia unconformably overlie the latest Paleogene deposits (Swezey 2009). The Neogene sandstones resulted from fluviatile system deposits in deltaic context over a long period of time, ranging from the Serravalian up to the late Tortonian (Belghithi et al. 2016). They are usually gathered in formations (Beglia Fm., Saouaf Fm., and Segui Fm.), but the variety of facies and the progradation of the system make lithostratigraphy unreliable at a regional scale. In Tunisia, the Neogene deposits yield two important fossil vertebrate faunas that provide constraints on the age and chronology of associated formations. First, the locality of Bled Douarah (Beglia Fm, western Tunisia) is assigned to the late Serravalian-early Tortonian in age (Werdelin 2010). Bled Douarah is divided in to two sedimentological units, likely corresponding to different environmental deposits and possibly climates (MannaïTayech 2009). The faunal assemblages in each unit differ. Only the upper unit has yielded equids (Robinson and Black 1969; Robinson and Black 1974) and seems to represent more forested and more humid conditions (Mannaï-Tayech 2009). The arrival of equids in Africa is estimated close to 10.5 Ma (early Tortonian; Bernor et al. 2010). Using the equid biotic marker, the earliest deposits referred to the Beglia Fm. are estimated to document deposits dating near the Serravalian/Tortonian transition (Biely et al. 1972; Mannaï-Tayech 2009; following Hilgen et al. 2012), or near the beginning of the marine regression recorded during the earliest Serravalian (13.8 Ma following 
Hilgen et al. 2012; Belghithi et al. 2016). Recently, a part of the Beglia Fm. in western Tunisia was correlated to the Saouaf Fm. in eastern Tunisia (Mannaï-Tayech 2009; Belghithi et al. 2016). The second fossil vertebrate fauna is from the Djebel Khechrem El Artsouma (Geraads 1989) and belongs to the Segui Fm., stratigraphically overlying the Beglia Fm. (Mannaï-Tayech 2009; Belghithi et al. 2016). This locality is estimated to be 0.5 to 1 myr more recent than the fauna from Bled Douarah (Geraads 1989).

Several other localities from the Neogene silicoclastic deposits of Tunisia are known but cannot be precisely dated due to the scarcity of the material or poorly time constrained taxa (e.g., (Mannaï-Tayech and Otero 2005).

\section{Anatomy and cladistics analyses}

The teeth description follows the dental nomenclature established for Hippopotamoidea (Boisserie et al. 2010). Tooth measurements follow Lihoreau et al. (2014). A calculation of the flattening index (fli) of the canine follows Kostopoulos et al. (2012), which consists of a ratio at the cervix between the mesio-distal length and the labiolingual length (Lmd/L11*100).

We consider the new fossil material described here as Libycosaurus algeriensis, a species previously described in Algeria (Ducrocq et al. 2001; Lihoreau, Hautier, et al. 2015). Some of this material complements the hypodigm of this species. The new material betters our knowledge of L. algeriensis, and facilitates inclusion of $L$. algeriensis into a phylogenetic matrix incorporating recent matrices assembled for deciphering internal phylogenetic relationships among taxa of the superfamily Hippopotamoidea (including the "Anthracotheriidae" and the Hippopotamidae). Here, we use the latest character matrices dealing with Merycopotamini (Lihoreau et al. 2016) and with Hippopotaminae (Boisserie et al. 2017), as well as some updates (supp. data). 
We added recent data for the species Bothriogenys andrewsi Schmidt, 1913, for which new material was recently published (Sileem et al. 2015), leading to better character scoring for Bo. andrewsi compared to previous analyses (Lihoreau, Boisserie, et al. 2015). Then, we added four new characters that deal with the morphological conditions describing the genus Libycosaurus with respect to the other genera. We coded, on lower molars, the morphology of the postentocristid (= entoconid fold, 63, supp. data) and the pattern of incomplete hypoconulid (80, supp. data); on upper molars, the relation between the mesostyle and cingulum (139, supp. data); and on the mandible, the presence and morphology of a notch (156, supp. data). We also added the position of the main palatine foramen, a diagnostic character in Merycopotamus species (162; Lihoreau et al. 2004; character already used in Boisserie et al. 2005). All characters are unordered and unweighted. Parsimony analyses were performed on the new matrix (64 taxa and 181 characters) with PAUP 4.0a164 (Swofford 2002) using heuristic searches with random step-wise addition (1000 replications with randomized input order of taxa) and tree-bisection-reconnection branch swapping options. We calculated the Bremer support for each node up to five supplementary steps.

\section{Systematic Paleontology}

Order Artiodactyla Owen, 1848

Suborder Cetancodonta Arnason et al., 2000

Superfamily Hippopotamoidea Gray, 1821 (sensu Gentry and Hooker 1988)

Subfamily Bothriodontinae Scott, 1940

Tribe Merycopotamini Lydekker, 1883

Genus Libycosaurus Bonarelli, 1947 
Type-Species. Libycosaurus petrocchii Bonarelli, 1947 (but see Lihoreau et al. 2014). Included Species. Libycosaurus anisae Black, 1972 from Bled Dourah and Djebel Kechrem el Artsouma, Tunisia (Geraads 1989), L. bahri Lihoreau et al., 2014 from Toros-Ménalla, Chad and As Sahabi Libya (Lihoreau et al. 2014), and L. algeriensis Ducrocq et al., 2001.

Stratigraphic range. Late Miocene (Tortonian to early Messinian). Geographic distribution. North and Central Africa (Libya, Algeria, Tunisia, Chad, Uganda).

Libycosaurus algeriensis Ducrocq et al., 2001

Holotype. Fragmentary left maxilla bearing M2/-M3/(UONM1).

New material. A right upper canine (SHI01), a fragment of right mandible preserving $\mathrm{P} / 3-\mathrm{M} / 2$ (SHI02), and a fragment of left mandible bearing M/3 (SHI03). This material is housed at the ONM, Tunis, Tunisia.

Type locality. Bir el Ater 2, Nementcha mountains, Algeria.

Other locality. Bir el Ater 3, Algeria (Lihoreau, Hautier et al. 2015), Sidi Hedri, north of Djebel Chambi, western part of central Tunisia (Fig. 1), and possibly Oluka, Kakara Fm. Uganda (Pickford 1991a).

Type horizon. Nementcha Fm., considered to be late Serravalian/early Tortonian in age (Lihoreau, Hautier, et al. 2015).

Diagnosis (emended from Lihoreau, Hautier and Mahboubi 2015). Smallest known species of the genus; retention of a small endometacristid on lower molars that connects 
the preprotocristid; ectocristylids form cusplets in the transverse valleys near a developed labial cingulid; only one postentostylid on the posthypocristulid separated to the hypoconulid apex by a lingual groove; enamel microstructure of molars retains large and blurry Hunter Schreger Bands; shallow mandible with a weak vascular impression; retention of a lingual cingulum around the protocone in upper molars, even in worn specimen.

Differential diagnosis. Libycosaurus algeriensis differs from other species of the genus (L. anisae and L. bahri) in its smaller dimensions with shallow mandible, the presence a small endometacristid on lower molars, the ectocristylids frequently developed in cusplets in the transverse valleys, which is rare in other species, the large lingual cingulum around the protocone of upper molars (even in worn specimens), and in the preprotocristid on $\mathrm{p} / 4$, which is directed mesially then lingually as in most Merycopotamini and unlike in the two other species of Libycosaurus. It also differs from L. anisae in the presence of only one entostylid on the third lobe of the M/3. It also differs from $L$. bahri in the presence of a posthypocristulid on $\mathrm{M} / 3$, the retention of a weak vascular impression on the mandible, and in the presence of large and blurry Hunter Schreger Bands on the tooth enamel.

\section{Comparative descriptions}

Upper canine (SHIO1). The crown apex is broken but wear facet and crown section are visible (Fig. 2). The cervix section is tear-shaped with a sharp distal keel, a swollen labial border and a flatter lingual border. The mesial border is rounded and bears the worn part of the tooth. The enamel appears thin and finely wrinkled. The whole tooth (crown plus root) is slightly inclined outward. The root is covered by cement, displays at least three constrictions toward the root apex, and remains open at its apex. 
Considering the canine morphology and the enamel ornamentation, both gathered conditions expected for a bothriodontine anthracothere. In Bothriodon velaunum Cuvier, 1824, an early Oligocene bothriodontine, the upper canine of males exhibits a clear demarcation at the cervix, with a smaller crown. On SHI01, the crown appears to be in continuity with the root. The SHI01 canine has a similar morphology of transverse section to that of Elomeryx, another Oligocene bothriodontine, but differs in being more transversally compressed (Flattening index $=53.6 \%$ in E. borbonicus (Geais, 1934; see Kostopoulos et al. 2012) and 60.9\% in SHI01). SHI01 is larger than E. borbonicus and lacks the serration on the distal keel that is visible on the canine of E. borbonicus.

Upper canines are known in few merycopotamine species. Afromeryx zelteni Pickford, 1991b, a stem Merycopotamini, displays a round and smaller upper canine section at the cervix (M82211). Merycopotamus medioximus Lihoreau et al., 2004, shows a canine of comparable dimension (Table 1, Fig. 2), with a similar wrinkled enamel characterized by longitudinal striations, and equivalent crown height proportion (NG104; Lihoreau et al. 2004). The labial border seems to be more swollen than in SHI01. There is a keel running on the distal border of the tooth, and a slight one is visible on the mesial border. In Merycopotamus dissimilis (Falconer and Cautley, 1836), the canine section is larger (Fig. 2), subcircular with slight distal and mesial keels in the three known specimens (Y49776, M16551, and M16552). The enamel covers at one third of the total length of the tooth. The root is closed and covered with cement in the only specimen where it is observable (Y49776; Lihoreau et al. 2007). Indeed, despite the marked similarities with the canine of M. medioximus, the SHI01 canine also shares anatomical traits with the canines of the two other species of Libycosaurus (L. anisae and L. bahri), notably in the lack of mesial keel, the presence of a lingual flattening of the crown section at the cervix, an open root apex, and in the presence of longitudinal 
grooves both on the labial and lingual sides of the root, which are not marked in canines of Merycopotamus (Pickford 2006; Lihoreau et al. 2014). The SHI01 canine has smaller dimensions at cervix than the upper canine of L. anisae (Black 1972; Pickford 2006) and that of L. bahri (Lihoreau et al. 2014; Fig. 2D; Table 1). It is also more curved. A similar small radius of curvature occurs in upper canines of Merycopotamus.

Lower premolars (P/3-4 on SHIO2). The premolars are narrow and dominated by a salient protoconid, which occupies a labial position (Fig. 3-4). A short and trenchant preprotocristid joins the mesio-lingual margin of the tooth. It is adorned with three successive small cusplets that decrease in height before reaching the mesial cingulid (Fig. 3A-B, Fig. 4A). Such an unusual cusplets organization/striation is typical of Merycopotamini, but such an amount of accessory cuspids on $\mathrm{P} / 3$ and $\mathrm{P} / 4$ is only known in species of Libycosaurus (Fig 4B-C) and in Hemimeryx blanfordi Lydekker, 1883 (Lihoreau et al. 2016; Fig. 4). The preprotocristid on P/4 has a mesial orientation near the protoconid apex and turns abruptly distally, a pattern proposed as a features of the Merycopotamini (Lihoreau et al. 2016; Fig. 4). This structure is less marked in the latest known Merycopotamini, such as L. anisae and L. bahri, and in M. dissimilis (Fig. 4B-C, F). The postprotocristid is slightly arched and has a lingual position with respect to the protoconid, also a Merycopotamini trait. The postprotocristid reaches a hypoconid and then the distal cingulid in a small distostylid (Fig. 4). An endoprotocristid emerges from the postprotocristid and reaches an entostylid (larger on $\mathrm{P} / 4$ than on $\mathrm{P} / 3$ ). The premolars are narrower than those of L. anisae and L. bahri (Table 1), and equal the size of Merycopotamus nanus Falconer, 1868 and Sivameryx spp. The P/4 seems slightly smaller than the only known $\mathrm{P} / 4$ of L. algeriensis (Ducrocq et al. 2001). The mandibular 
depth below M/1 is similar to the mean depth in Sivameryx spp. (Table 1) and to the lowest values of $M$. nanus and M. medioximus.

Lower molar. Unfortunately, the right lower molars M/1-2 preserved on SHI02 are worn and badly preserved. The M/1 is similar in size to that of Sivameryx and Merycopotamus spp. (Table 1). The left M/3 is well preserved (SHI03; Fig. 5) and displays a bothriodontine pattern, which is characterized by an important development of the cristids, notably the long prehypocristid that reaches the lingual margin of the tooth. It also exhibits some Merycopotamini characters such as the lack of connection between the premeta- and preprotocristids, and the pinched loop-like hypoconulid (Lihoreau et al. 2016). Furthermore, the SHI03 M/3 lacks the premetacristid, displays a pinched postentocristid between the entoconid and the posthypocristid, and a notched posthypocristulid (an incomplete loop-like hypoconulid), all of which are diagnostic traits of Libycosaurus (Lihoreau, Hautier, et al. 2015). Mesial to the posthypocristulid notch, there is a marked postentostylid. This pattern is observed in all known specimens of L. algeriensis and some M. medioximus. However, it differs from that characterizing $\mathrm{M} / 3$ of $L$. anisae where there are many stylids without a clear groove separating the entostylid from the rest of the posthypocristulid, and from that of L. bahri, where the tooth lacks the posthypocristulid (Lihoreau, Hautier, et al. 2015). Lingual cuspids of lower molar are more linguo-labially flattened in L. algeriensis, whereas they present a rounded outline (in occlusal view) in other species of Libycosaurus. This is probably due to development of sharper cristids in L. algeriensis than in the other species. This condition also exists in early species of Merycopotamus.

Compared to L. anisae and L. bahri, the M/3 (SHI03) shows a blurry endometacristid, not as developed as in Sivameryx, but similar to that observed in some 
specimens of Merycopotamus. Such a very small endometacristid is observed in material of L. algeriensis from Algeria (Lihoreau, Hautier, et al. 2015).

There is a cusplet within the transverse valley that could be considered as an inflated ectocristilid as it joins the labial cingulid, forming small ectostylid. This pattern is known in most of specimens of L. algeriensis (6 of the 7 known lower molars). We also observed this structure within Merycopotamini, notably in some specimens of $M$. nanus (almost 4 of 15 molars) and in Sivameryx (close to 5 on 11 molars). In contrast, the ectocristilid in L. anisae and L. bahri do not form a cusplet (or rarely: 0 and 1 on at least 23 and 40 lower molars, respectively) but form an alignment of the enamel knob instead. The SHI03 M/3 is similar in size to the specimens from Bir el Ater 2 and 3 (UONM10, 9 and 14; Fig. 5; Lihoreau, Hautier, et al. 2015) and also very close to the mean value of $M$. medioximus (Table 1).

\section{Phylogeny}

Heuristic searches have yielded 18 equally most parsimonious trees of 1226 steps each $(\mathrm{CI}=0.30 ; \mathrm{RI}=0.64)$. A strict consensus tree is provided in Figure 6 . The phylogenetic relationships are particularly well resolved, despite an apparent important number of homoplasies. The latter are much involved in the structure of the tree. The observed polytomies concern relationships between the two Kenyapotamus species and the Hippopotaminae, between Sivameryx spp. and Hemimeryx, and within the clade Brachyodus spp. + Bothriogenys andrewsi. The latter is mainly due to the small number of characters scored for Bo. andrewsi (few known fossil remains) and uncertainties regarding Brachyodus, suggesting a need for a revision of its evolutionary history. However, this study proposes Bo. andrewsi as a basal member of the Brachyodus clade, thereby representing the only Paleogene representative of that clade (this would suggest 
a generic re-attribution of the species Bo. andrewsi; i.e. Brachyodus andrewsi following Schmidt 1913). Our phylogenetic analyses, based on the characters used here (Lihoreau et al. 2016), fail to discriminate the genus Sivameryx from Hemimeryx. The two genera are considered phylogenetically close and differ mainly by their upper molar morphologies notably the dimension of the paraconule (Lihoreau et al. 2016). In the resulting tree the paraconule reduction appears as a reversion in Sivameryx. Further phylogenetic analysis should therefore add more Sivameryx species to discuss this particular point. Unfortunately, new material of Sivameryx moneyi (Fourtau, 1918) from Wadi Moghra (Miller et al. 2014) cannot be included in this cladistic analysis due to the lack of published description for the upper tooth. It is worth noting here that one specimen of S. moneyi (CUWM 172) displays five upper premolars (Miller et al. 2014) as in all the specimens of the two well-known species of Libycosaurus (Lihoreau et al. 2006; Pickford 2006). Therefore, unlike what is proposed by Miller et al. (2014, p.974), this is not 'a fairly common occurrence among anthracothere species in general', and should hence be tested in order to decipher possible close affinities between S. moneyi and Libycosaurus.

The main clades depicted from this analysis, which display Bremer indices (BI) of 3 or more (Fig. 6), are those of the suines, anthracotheriines, hippopotamids + Epirigenys lokonensis Lihoreau, Boisserie, et al., 2105, hippopotamids, hippopotamins, bothriodontines, Brachyodus spp. + Bo. andrewsi and merycopotamins (Fig. 6). The main aim of this analysis was to assess the phylogenetic position of L. algeriensis within the Merycopotamini. Therefore, we will here focus primarily on the description of the nodes that gather the species of Merycopotamus and those of Libycosaurus.

First, the Merycopotamus + Libycosaurus clade $(\mathrm{BI}=5)$ is characterized by nine non-ambiguous traits: the presence of a groove on the labial side on the lower canine 
$\left(12^{1}\right)$, also observed in Suina, the lack of ectometafossid on lower molars (54 $)$, a character convergent with some Bothriodontinae and Hippopotaminae, an important regression or lack of the endometacristid on lower molars $\left(55^{\circ}\right)$, which is convergent with the Hippopotamidae, Brachyodus ( + Bo. andrewsi) and stem Hippopotamoidea, the lack of premetafossid on lower molars $\left(57^{1}\right)$, convergent with Brachyodus, E. borbonicus and Myaingtherium, a reduced postectoentocristid $\left(60^{1}\right)$, which appears as a reversion in Hippopotamoidea, a convex mesial border of $\mathrm{P} 4 /\left(105^{1}\right)$, also observed in some Bothriodontinae (Bothriodon, Aepinacodon and S. africanus (Andrews, 1914), the lack of postectoprotocrista $\left(114^{0}\right)$, as in Hippopotaminae, some microbunodontines and Siamotherium, a maximal thickness in the middle of the sagittal section of the symphysis $\left(153^{\circ}\right)$, as in Hippopotamidae and Anthracotherium, and the presence of a mandibular notch with a short extension below $\mathrm{m} / 3\left(156^{2}\right)$, as observed in $E$. borbonicus.

Merycopotamus nanus is the sister-taxon of a clade including the other species of Merycopotamus (successively arranged) and the three species of Libycosaurus, the latter forming a subclade. This Merycopotamus- Libycosaurus clade is supported (BI= 5) by six non ambiguous traits: crown of the male lower canine with a prolonged growth $\left(15^{2}\right)$, also known in Hippopotamidae and Suina, the presence of a postentocristilid on P/4 (421), convergent with Hippopotamidae, Elomeryx spp., S. palaeindicus and Microbunodon minimum (Cuvier, 1822) upper canine with prolonged growth of the root $\left(86^{2}\right)$, convergent with Suina, a partial to total division of the mesostyle on upper molars $\left(140^{1}\right)$, also observed in Bothriodon, Aepinacodon and Elomeryx borbonicus, a bony fusion of the mandibular symphysis in adult $\left(152^{1}\right)$, a character highly convergent within Hippopotamoidea but characteristic of several Merycopotamini, and the presence 
of an inner radial enamel (schmelzmuster with 3 layers, 164' $)$, which is highly convergent within Hippopotamoidea.

Merycopotamus dissimilis and the three species of Libycosaurus form a wellsupported clade $(\mathrm{BI}=5)$ characterized by six non-ambiguous traits, including a nonhomoplastic apomorphy of the Hippopotamoidea. This exclusive trait is the presence of an ectometacristule developed on the last upper molars (not M1/; 1182). This character differs from the condition observed in other Hippopotamoidea where the ectometacristule is expressed on M1/ and also from other Merycopotamini where the ectometacristule is absent. The other unambiguous traits are the presence of a postentocristid $\left(62^{1}\right)$, which is also observed in some Bothriogenys, Hippopotamidae, Anthracotheriinae, although this postentocristid is mesio-distally oriented between the posthypocristid and the entoconid (= the entoconid fold in Lihoreau et al. 2007) and only observed in S. africanus among the Hippopotamoidea $\left(63^{1}\right)$, the presence of an ectostylid on lower molars $\left(72^{2}\right)$, also known in Hippopotamidae and stem Hippopotamidae, in E. borbonicus, S. africanus and in H. blanfordi, an incomplete posthypocristulid (79'1), also known in Afromeryx zelteni and Chororatherium, the rostral opening of the main palatal foramen $\left(162^{2}\right)$, which is a character convergent with Hippopotamidae and B. onoideus (Gervais, 1848-52).

The three species of Libycosaurus are gathered together $(\mathrm{BI}=4)$ on the basis of four non-ambiguous traits including two non-homoplastic apomorphies: the presence of at least two accessory cusplets on the preprotocristid of all lower premolars $\left(18^{2}\right)$ and a long postentocristilid on $\mathrm{P} / 4$ that reaches the distal cingulid $\left(42^{2}\right)$. Both character states are derived condition of what is known in Merycopotamini $\left(18^{1}\right)$ or Merycopotamus $\left(42^{1}\right)$. The other two non-ambiguous traits are the endoprotofossid on $\mathrm{P} / 4$ that reaches the lingual cingulid wall (ectocristilid; $41^{1}$ ), a character which is convergent with $E$. 
borbonicus, A. zelteni and S. africanus within the Bothriodontinae, and that is linked to the important development of the ectocristilid (42 $1-2)$, and finally the cingulum reduction at the mesostyle $\left(139^{2}\right)$, which is convergent with Brachyodus spp., Bothriogenys fraasi (Schmidt, 1913) and Bo. andrewsi, Hippopotamidae, Bothriodon, Aepinacodon and Hemimeryx.

In our cladistic analysis, Libycosaurus algeriensis forms the earliest offshoot of the Libycosaurus lineage, appearing as the sister-taxon of the two other species of the genus (L. anisae and L. bahri). The latter clade shows two non-ambiguous traits, including one non homoplastic synapomorphy: the preprotocristid direction on $\mathrm{P} / 4$ is lingual and then mesial $\left(43^{1}\right)$, whereas it is mesial then lingual in other Merycopotamini. The other non-ambiguous trait is the lack (loss) of the mandibular notch, mesial to the vertical ramus $\left(156^{\circ}\right)$, which is convergent with Afromeryx and the Hippopotaminae.

\section{Discussion}

\section{The age of Tunisian silicoclastic formations}

The new anthracothere fossil remains from Sidi Hedri are the first known for the species Libycosaurus algeriensis in Tunisia. Based on the determination of these fossils, we can postulate that the sedimentary deposits where these fossils were found, are most likely contemporaneous with the Nementcha Fm. in Algeria, inasmuch as Libycosaurus algeriensis was originally described from that rock unit (Fig. 1; Ducrocq et al. 2001; Mahboubi et al. 2003; Lihoreau, Hautier, et al. 2015). Libycosaurus algeriensis does not display some of the derived morphological traits characterizing L. anisae and L. bahri, and has so far never been found in association with those species. Evolutionary trends observed in the genus, notably general size increase and reduction of molar crests 
suggest that L. algeriensis represents the most primitive known species of the genus (Lihoreau, Hautier, et al. 2015). This suggests an earlier origin for Libycosaurus. This view is corroborated here by the results of our phylogenetic analysis, which included more characters and a better scoring of the matrix for some taxa, notably L. algeriensis. Indeed, L. algeriensis was previously known only by 14 elements (upper molars, lower molars, a fragmentary mandible, and a lower P/4 (Ducrocq et al. 2001; Lihoreau, Hautier, et al. 2015). The new material has substantially improved the hypodigm of the earliest species of Libycosaurus, and thus permitted to assess its phylogenetic relationships. The phylogenetic results presented here recover the monophyly of the Libycosaurus genus with L. algeriensis falling as the sister of L. anisae and L. bahri (more recent species). The Libycosaurus clade is nested within a paraphyletic Merycopotamus clade. The morphological characters in support of the Libycosaurus clade (e.g., accessory cusplets on lower premolars) were already included in the amended diagnosis of the genus (Lihoreau et al. 2014). Thanks to the new fossil material and based on the phylogenetic results, we could add some aspects of the morphology of the $\mathrm{P} / 4$ (e.g., long ectocristilid including the distal development of the endoprotofossid) and of the upper molars (cingulum reduction at mesostyle) to the genus diagnosis.

A key point of this discovery is the identification of two diachronous species of Libycosaurus (L. algeriensis and L. anisae) in similar facies of silicoclastic deposits, which were previously combined as Beglia Fm. We propose that either (1) that different formations of late middle to early late Miocene sandstones were deposited in Tunisia and therefore that all ochre sandstones should not be considered by default as documenting (belonging to) the Beglia Fm., or (2) that the Beglia Fm. records deposits 
corresponding to a long period of time, which require that they be separated into different ages.

Within the Beglia Fm., the locality of Bled Douarah (including two levels) was dated around 10.5 Ma (arrival in Africa of hipparions following Bernor et al. 2010). The Libycosaurus from both levels do not show morphological discrimination (Black 1972) or biometrical difference (Fig. 5). Therefore, this material may documents one unique species, L. anisae, documenting a similar evolutionary grade. Thus, these two levels might not represent a long time-span. The base of the Beglia Fm. may be early Tortonian (11.6 Ma; Hilgen et al. 2012) or recording the earliest sediments corresponding to the onset of the Serravalian marine regression (13.8 Ma; Hilgen et al. 2012). We can add here that the Beglia Fm. corresponds to a long regressive sequence, and that the sediments characterizing the Sidi Hedri locality are also within regressive deposits, and furthermore are older than the Bled Douarah low level.

Another important point is that the Libycosaurus clade shares a common ancestry with Merycopotamus dissimilis and might originate from a M. medioximus-like ancestral stock (Fig. 6). Merycopotamus medioximus is known from 10.4 Ma to 8.6 Ma in deposits recorded in the Potwar Plateau (Pakistan; Fig. 7; Lihoreau et al. 2007). The latter area displays successive species of Merycopotamus, thereby suggesting a possible anagenetic lineage in this case. Some transitional form between M. nanus and M. medioximus are present between 11.3 and 10.5 Ma. Therefore, a possible age for Libycosaurus algeriensis could be bracketed between the earliest $M$. medioximus-like ancestral stock (11.3 Ma) and the earliest level of Bled Douarah (older than 10.5 Ma).

\section{The impact of the Tortonian/Serravalian marine regression on Libycosaurus}

\section{dispersal}


The phylogenetic and geographic origins of Libycosaurus are deduced from results of the cladistics analysis (Fig. 6). Although Libycosaurus was proposed as sister-taxon of the Merycopotamus clade in previous analyses (Lihoreau et al. 2006; Lihoreau et al. 2014), Libycosaurus was supposed to originate from a M. nanus-like ancestral stock from Asia (Lihoreau et al. 2014). From the phylogenetic results presented here, proposing that Libycosaurus is in fact nested within the Merycopotamus radiation, the arrival in Africa of the ancestor of Libycosaurus corroborates the hypothesis of a dispersal event from Asia to Africa as proposed by Lihoreau et al. $(2006,2014)$. However, the derivation of Libycosaurus would be related to a M. medioximusdissimilis like ancestral stock, rather than a M. nanus-like ancestral stock. In this context, the origin of Libycosaurus would be viewed as more recent (later) than coeval to the Merycopotamus origin, as formerly suggested by earlier phylogenetic results (Lihoreau et al. 2006; Lihoreau et al. 2014). Accordingly, the genus Merycopotamus becomes paraphyletic in this phylogenetic context. However, in order for maintaining systematics stability, we propose here that all the species of Libycosaurus belong to Merycopotamus (following Black 1972), and that Libycosaurus represents an African subgenus of Merycopotamus. This taxonomic option requires additional paleontological evidence (documenting for instance the number of premolars in L. algeriensis) to further test this new systematic proposal.

The new fossil material from Tunisia provides key arguments for rooting the origin of Libycosaurus near the origin of Merycopotamus dissimilis, most probably from a M. medioximus-like ancestral stock in Asia. The latter species, contrary to its precursors, points at widespread distribution characterized by a sudden expansion out of the Indian sub-continent, reaching South-East Asia and Middle East (Lihoreau et al. 2007). This species most probably underwent disruptive evolution in different region of 
Asia, with distinct populations in Thailand (a skull has been considered as a new species M. tachangensis Hanta et al., 2008, which is considered as slightly derived from $M$. medioximus) and in Iraq (Brunet and Heintz 1983; Lihoreau et al. 2007). We consider that a population of Merycopotamus (close to the evolutionary degree of $M$. medioximus) extended its range and shifted westward to reach Africa.

The Indian sub-continent is bordered by mountainous arc that limited the distribution of anthracotheres outside, at least until the early Tortonian. Following Lihoreau et al. (2007) and in accordance with freshwater-constrained distribution of the anthracotheres (Lihoreau et al. 2014), the dispersal out of the Indian sub-continent might have been facilitated by a major eustatic event (low sea-level) that would have connected main river mouths in South Asia. In this province, the Tiger River and Euphrates River, as well as the Indus River could have been involved in the connection between Middle East and the Indian sub-continent, thus generating a possible dispersal pathway for anthracotheres. Recent sedimentological and tectonical studies support the existence of these proposed rivers connections. During the Burdigalian (early Miocene), fan deposits of the Paleo-Indus River contact those of a river system north of the extant Tiger River (Barrier et al. 2018). During this period important dispersal events involving many mammalian species occurred between Asia and Africa. These are most famously exemplified by the "Gomphotherium landbridge" in the Middle East (e.g. Sen 2013). At this time two anthracotheres genera, Sivameryx and Afromeryx, dispersed from the Indian sub-continent to Africa (Holroyd et al. 2010). We suggest that this Burdigalian dispersal was possible due to river mouth connections. In the same way, we propose that a new connection between the same river mouths facilitated a dispersal of anthracotheres from Indian sub-continent to Africa during Neogene (Tortonian). 
The stratigraphical sequence where the earliest Libycosaurus (i.e., L. algeriensis) is found corresponds to a marine regression phase. The environmental condition of deposits characterizing the whole Beglia Fm., would correspond to this kind of eustatic event (Belghithi et al. 2016). In contrast, the sediments of the Saouaf Fm. correspond to a marine transgressive sequence (Belghithi et al. 2016). We hypothesize that first, the dispersal took place during a regression event or second, at the regression maximum. A main regression event is recorded between $12 \mathrm{Ma}$ and 10.5 Ma in US mid-Atlantic coastal plain (Kominz et al. 2008), and between 12.1 Ma and 10.9 Ma in the northeastern Australian margin (John et al. 2011). This event is framed by the Mi5 and Mi6 isotopic event (Haq et al. 1988; Westerhold et al. 2005; John et al. 2011). The sea level drop is estimated close to $50 \mathrm{~m}$, with a lowstand at 10.4-10.9 Ma (John et al. 2004; Westerhold et al. 2005; Kominz et al. 2008). This event permitted the extension of the hydrographical networks that may have connected temporarily the river mouths of Paleo-Indus River and a paleo-river north to the Tiger River, and likely allowed semiaquatic mammals to disperse outside the Alpine arc. Following the distributions of fluvio-lacustrine deposits during the Tortonian (Barrier et al. 2018), connections are possible between the Tiger-Euphrate water system and the main trans-Saharan drainage systems as the Nile rivers (Bussert et al. 2018) and the Sahabi rivers (Griffin 2010), providing large dispersal pathway from Middle East to North Africa for fresh-water aquatic mammals.

This dispersal event could therefore serve as a marker to precisely determine the age of the first Libycosaurus arrival in Africa at the base of the Tortonian, between 11.3 Ma (the earliest occurrence of a M. medioximus-like representatives) and 10.9 Ma or 10.5 $\mathrm{Ma}$ (the minimal sea level). This age is crucial for dating the Nementcha Fm. in Algeria and the early phase of deposition of the Beglia Fm. (earlier than Bled Douarah), 
both of which record the occurrence of the most primitive species of Libycosaurus ( $L$. algeriensis). Moreover, the record of Libycosaurus in the late Miocene of Oluka in Uganda (Pickford 1991a), indicates that connections between North and East Africa were possible for semi-aquatic mammals, thereby constraining the age of the onset of the Sahara. The specimen, an upper molar, from the Kakara Fm, Uganda, was attributed to Libycosaurus cf. anisae (Pickford 1991a) and to L. petrocchii (Simon et al. 2017), even if the latter must only be restricted to its holotype (see Lihoreau et al. 2014). It is difficult to discriminate Libycosaurus species on upper molar morphology but its small size could eventually correspond to a very small specimen of L. anisae (Pickford 1991a) or to a specimen of L. algeriensis. The age of this specimen is proposed to be early Tortonian (Simon et al. 2017), and it is worth noting that this specimen was found in association with Tetralophodon, as is the case at Bir el Ater 3 (Lihoreau, Hautier, et al. 2015). In sum, the Ugandan specimen, as well as the Algerian and the Tunisian materials might represent evidence of the first arrival of Libycosaurus in Africa. Besides, the apparent widespread distribution of this taxon would indicate riverine connections between East and North Africa during the early Tortonian. This element brackets the age of the Saharan onset after 10.5 Ma to at least a new period of near-river connection within Sahara, near 7 Ma (Griffin 2002; Lihoreau et al. 2006; Otero et al. 2009).

\section{Conclusions}

The evolution of Libycosaurus toward a more aquatic life style, a grazer diet and gregarious habit is not a convergent history with Merycopotamus, but the same history that took place in Africa. Libycosaurus algeriensis is here considered as 
morphologically more advanced than Merycopotamus nanus, and thus already in course of global ecological shift. Additional paleontological support documenting this species, notably cranial elements, would be necessary for substantiating a new systematic hypothesis according to which Libycosaurus would be a subgenus of Merycopotamus. Our estimate regarding the dating of the new Tunisian Sidi Hedri locality, where we discovered fossil remains attributable to Libycosaurus algeriensis, suggests an age close to the base of Tortonian. Libycosaurus algeriensis represents the most ancient record of the genus in Africa so far. Libycosaurus algeriensis probably documents a species morphologically close to its Asian ancestor who probably dispersed to Africa only shortly before the first appearance of Libycosaurus in the fossil record of Africa. This corresponds to an important African event prior to the Hipparion Datum and thus helps resolving African Neogene biochronology more precisely. A thorough review of biostratigraphical correlations of Tunisian Neogene formations using vertebrate fossil data should improve resolution of the local history for establishing an important scale for the Middle-Late Miocene transition in Africa. 


\section{Acknowledgment}

We would like to thank Baba El-Hadj Mallah, Clarisse Nekoulnang, and Mahamat Adoum (CNRD, N’Djaména, chad), Michèle Morgan and John Barry (Peabody Museum of Harvard University, Cambridge, USA), Wilma Wessels (Utrecht University, Utrecht, Netherland), and Mohammed Mahboubi (Université d'Oran 2, Oran, Algeria) for granting us access to the collection in their care. We also acknowledge Suzanne Jiquel for sample preparation and casting. We thank the anonymous reviewers for their help to improve this manuscript. Fieldwork and post-field researches were supported by the French ANR-ERC PALASIAFRICA (ANR-08-JCJC-0017) and has also benefit from the French ANR program SPLASH (ANR-15-CE32-0010-01) and from grant of the Scientific Council of University of Montpellier.

\section{Declaration of interest statement}

\section{References}

Andrews CW. 1914. On the Lower Miocene Vertebrates from British East Africa, collected by Dr. Felix Oswald. Quart Journ Geol Soc. 70(1-4):163-NP.

Arnason U, Gullberg A, Gretarsdottir S, Ursing BM, Janke A. 2000. The mitochondrial genome of the sperm whale and a new molecular reference for estimating eutherian divergence dates. J Mol Evol. 50:569-578.

Barrier E, Vrielynck B, Brouillet JF, Brunet MF. (Contributors : Angiolini L, Kaveh F, Poisson A, Pourteau A, Plunder A, Robertson A, Shekawat R, Sosson M, Zanchi A) 2018. Paleotectonic Reconstruction of the Central Tethyan Realm. TectononoSedimentary-Palinspastic maps from Late Permian to Pliocene. Paris: Commission for the Geological Map of the World.

Belghithi H, Boulvain F, Yaich C, Da Silva AC. 2016. Évolution des séries silicoclastiques miocènes en Tunisie centrale : Cas de la coupe de Khechem El Artsouma. Carnets Géologie Note Geol. 16(23):557-568. doi:10.4267/2042/61846.

Bernor RL, Armour-Chelu MJ, Gilbert H, Kaiser TM, Schulz E. 2010. Equidae. In: Werdelin L, Sanders WJ, editors. Cenozoic Mammals of Africa. Berkeley, Los Angeles, London: University of California Press. p. 685-721. 
Biely A, Rakus M, Robinson P, Salaj J. 1972. Essai de corrélation des formations miocènes au sud de la dorsale tunisienne. Notes Serv Géologie Tunis. 38(7):73-92.

Black CC. 1972. A new species of Merycopotamus (Artiodactyla: Anthracotheriidae) from the late Miocene of Tunisia. Notes Serv Géologie Tunis. 37:5-39.

Boisserie JR, Fisher RE, Lihoreau F, Weston EM. 2011. Evolving between land and water: key questions on the emergence and history of the Hippopotamidae (Hippopotamoidea, Cetancodonta, Cetartiodactyla). Biol Rev. 86(3):601-625.

Boisserie JR, Lihoreau F, Brunet M. 2005. Origins of Hippopotamidae (Mammalia, Cetartiodactyla): towards resolution. Zool Scr. 34(2):119-143.

Boisserie JR, Lihoreau F, Orliac M, Fisher RE, Weston EM, Ducrocq S. 2010. Morphology and phylogenetic relationships of the earliest known hippopotamids (Cetartiodactyla, Hippopotamidae, Kenyapotaminae): Kenyapotamus and Hippopotamid Origins. Zool J Linn Soc. 158(2):325-366.

Boisserie JR, Suwa G, Asfaw B, Lihoreau F, Bernor RL, Katoh S, Beyene Y. 2017. Basal hippopotamines from the upper Miocene of Chorora, Ethiopia. J Vertebr Paleontol. e1297718. doi:10.1080/02724634.2017.1297718.

Bonarelli G. 1947. Dinosauro fossile del Sahara Cirenaico. Riv Biol Colon Roma. 8:2333.

Brunet M, Heintz E. 1983. Interpretation paleoecologique et relations biogeographiques de la faune de vertébrés du Miocène inférieur d'Injana, Irak. Paleogeogr Palaeoclimatol Palaeoecol. 44:283-293.

Bussert R, Eisawi AAM, Hamed B, Babikir IAA. 2018. Neogene palaeochannel deposits in Sudan - Remnants of a trans-Saharan river system? J Afr Earth Sci. 141:921.

Cuvier, G., 1822. Recherches sur les ossemens fossiles, où l'on rétablit les caractères de plusieurs animaux, dont les révolutions du globe ont détruit les espèces, Tome V, Paris: E. d'Ocagne.

Cuvier G. 1824. Recherches sur les ossemens fossiles: où l'on rétablit les caractères de plusieurs animaux dont les révolutions du globe ont détruit les espèces, Tome $\mathrm{V}$, partie II. Paris: G. Dufour et E. D'Ocagne.

Ducrocq S. 1995. The contribution of Paleogene anthracotheriid artiodactyls in the paleobiogeographical history of southern Europe. Neues Jahrb Geol P M. 6:355-362.

Ducrocq S, Coiffait B, Coiffait PE, Mahboudi M, Jaeger JJ. 2001. The Miocene Anthracotheriidae (Artiodactyla, Mammalia) from the Nementcha, eastern Algeria. Neues Jahrb Geol P M. 3:145-156.

Falconer H. 1868. Palaeontological memoirs. London: R. Hardwicke.

Falconer H, Cautley PT. 1836. Note on the fossil Hippopotamus of the Siwalik hills. Asiatic Res. 19: 39-53. 
Fourtau R. 1918. Contributions à l'étude des Vertébrés Miocènes de l'Egypte. Cairo: Geological Survey of Egypt.

Geais G .1934. Le Brachyodus borbonicus des argiles de St Henri (près Marseille). Trav Lab Géo Fac Sci Lyon Mém. 21:1-54.

Gentry AW, Hooker JJ. 1988. The phylogeny of the Artiodactyla. In: Benton MJ, editor. The phylogeny and classification of the Tetrapods, Volume 2: Mammals, vol. 35B. Systematics Association Special Volume. Oxford: Clarendon Press; p. 235-272.

Geraads D. 1989. Vertébrés fossiles du Miocène supérieur du Djebel Krechem et Artsouma (Tunisie centrale). Comparaisons biostratigraphiques. Geobios. 22(6):777801.

Gervais P. 1848-52. Zoologie et paléontologie françaises: nouvelles recherches sur les animaux vivants et fossiles de la Franc e. Paris: A. Bertrand.

Grandi F, Bona F. 2017. Prominatherium dalmatinum from the late Eocene of Grancona (Vicenza, NE Italy). The oldest terrestrial mammal of the Italian peninsula. Comptes Rendus Palevol. 16(7): 738-745.

Gray JE. 1821. On the natural arrangement of vertebrose animals. London Med Reposit. 15: $296-310$.

Griffin DL. 2002. Aridity and humidity: two aspects of the late Miocene climate of North Africa and the Mediterranean. Paleogeogr Palaeoclimatol Palaeoecol. 2808:1-27.

Griffin DL. 2011. The late Neogene Sahabi rivers of the Sahara and the hamadas of the eastern Libya-Chad border area. Paleogeogr Palaeoclimatol Palaeoecol. 309:176-185.

Hanta R, Rathanastien B, Kunimatsu Y, Saegusa H, Nakaya H, Nagaoka S, Jintasakul P. 2008. A new species of Bothriodontinae, Merycopotamus thachangensis (Cetartiodactyla, Anthracotheriidae) from the late Miocene of Nakhon Ratchasima, Northeastern Thailand. J Vertebr Paleontol. 28(4):1182-1188.

Haq BU, Hardenbol J, Vail PR. 1988. Mesozoïc and Cenozoïc chronostratigraphy and cycles of sea level change. In: Wilgus CK, Posamentier C, Ross CA, Kendall CG, editors. Sea level changes-An integrated approach. Vol. 42. Tulsa: Society of Economic Paleontologist and Mineralogist, special publication. p. 71-109.

Hartenberger JL, Crochet JY, Martinez C, Marandat B, Sigé B. 2001. The Eocene mammalian fauna of Chambi (Tunisia) in its geological context. In: Gunnell GF, editor. Eocene Biodiversity. Vol. 18. Boston, MA: Springer US. p. 237-250.

Hilgen FJ, Lourens LJ, Van Dam JA. 2012. The Neogene Period. In: Gradstein FM, Ogg JG, Schmitz M, Ogg G. The Geologic Time Scale. Amsterdam: Elsevier. p. 923978.

Holroyd PA, Lihoreau F, Gunnell GF, Miller ER. 2010. Anthracotheriidae. In: Werdelin L, Sanders WJ. Cenozoic mammals of Africa. Berkeley: University of California press. p. 843-851. 
John CM, Karner GD, Browning E, Leckie RM, Mateo Z, Carson B, Lowery C. 2011. Timing and magnitude of Miocene eustasy derived from the mixed siliciclasticcarbonate stratigraphic record of the northeastern Australian margin. Earth Planet Sci Lett. 304(3-4):455-467.

John CM, Karner GD, Mutti M. 2004. $\delta 180$ and Marion Plateau backstripping: combining two approaches to constrain late middle Miocene eustatic amplitude. Geology. 32(9):829-832.

Kominz MA, Browning JV, Miller KG, Sugarman PJ, Mizintseva S, Scotese CR. 2008. Late Cretaceous to Miocene sea-level estimates from the New Jersey and Delaware coastal plain coreholes: an error analysis. Basin Res. 20(2):211-226.

Kostopoulos DS, Koufos GD, Christanis K. 2012. On some anthracotheriid (Artiodactyla, Mammalia) remains from northern Greece: comments on the palaeozoogeography and phylogeny of Elomeryx. Swiss J Palaeontol. 131(2):303-315.

Lihoreau F, Alloing-Séguier L, Antoine PO, Boisserie JR, Marivaux L, Métais G, Welcomme JL. 2016. Enamel microstructure defines a major Paleogene hippopotamoid clade: the Merycopotamini (Cetartiodactyla, Hippopotamoidea). Hist Biol. 29(7):947957.

Lihoreau F, Barry J, Blondel C, Brunet M. 2004. A new species of Anthracotheriidae, Merycopotamus medioximusnov. sp. from the Late Miocene of the Potwar Plateau, Pakistan. Comptes Rendus Palevol. 3(8):653-662.

Lihoreau F, Barry J, Blondel C, Chaimanee Y, Jaeger JJ, Brunet M. 2007. Anatomical revision of the genus Merycopotamus (Artiodactyla; Anthracotheriidae): its significance for Late Miocene mammal dispersal in Asia. Palaeontology. 50(2):503-524.

Lihoreau F, Boisserie JR, Blondel C, Jacques L, Likius A, Mackaye HT, Vignaud P, Brunet M. 2014. Description and palaeobiology of a new species of Libycosaurus (Cetartiodactyla, Anthracotheriidae) from the Late Miocene of Toros-Menalla, northern Chad. J Syst Palaeontol. 12(7):761-798.

Lihoreau F, Boisserie JR, Manthi FK, Ducrocq S. 2015. Hippos stem from the longest sequence of terrestrial cetartiodactyl evolution in Africa. Nat Commun. 6:6264. doi: $10.1038 /$ ncomms 7264 .

Lihoreau F, Boisserie JR, Viriot L, Coppens Y, Likius A, Mackaye HT, Tafforeau P, Vignaud P, Brunet M. 2006. Anthracothere dental anatomy reveals a late Miocene Chado-Libyan bioprovince. Proc Natl Acad Sci USA. 103(23):8763-8767.

Lihoreau F, Ducrocq S. 2007. The Family Anthracotheriidae. In: Protero DR, Foss SE, editors. The evolution of Artiodactyls. John Hopkins University Press. p.89-105.

Lihoreau F, Hautier L, Mahboubi M. 2015. The new Algerian locality of Bir el Ater 3: validity of Libycosaurus algeriensis (Mammalia, Hippopotamoidea) and the age of the Nementcha Formation. Palaeovertebrata. 39 (2):e1. doi:10.18563/pv.39.2.e1.

Lydekker R. 1883. Siwalik selenodont Suina. Palaeontol Indica. 10:143-177. 
Mahboubi M, Tabuce R, Mebrouk F, Coiffait B, Coiffait PE, Jaeger JJ. 2003. L'éocène continental à vertébrés de la bordure sud des monts des Nementcha (Atlas saharien oriental, Algérie). Bull Serv Géologique Algér. 14(1):27-35.

Mannaï-Tayech B. 2006. Les séries silicoclastiques miocènes du Nord-Est au SudOuest de la Tunisie : une mise au point. Geobios. 39(1):71-84.

Mannaï-Tayech B. 2009. The lithostratigraphy of Miocene series from Tunisia, revisited. J Afr Earth Sci. 54(3-4):53-61.

Mannaï-Tayech B, Otero O. 2005. Un nouveau gisement miocène à ichthyofaune au sud de la chaîne des Chotts (Tunisie méridionale). Paléoenvironnement et paléobiogéographie. Comptes Rendus Palevol. 4(5):405-412.

Marivaux L, Essid EM, Marzougui W, Khayati Ammar H, Merzeraud G, Tabuce R, Vianey-Liaud M. 2015. The early evolutionary history of anomaluroid rodents in Africa: new dental remains of a zegdoumyid (Zegdoumyidae, Anomaluroidea) from the Eocene of Tunisia. Zool Scri. 44:117-134.

Miller ER, Gunnell GF, Gawad MA, Hamdan M, El-Barkooky AN, Clementz MT, Hassan SM. 2014. Anthracotheres from Wadi Moghra, early Miocene, Egypt. J Paleontol. 88(5):967-981.

Mourer-Chauviré C, El Mabrouk E, Khayati H, Marivaux L, Marzougui W, Temani R, Vianey-Liaud M, Tabuce R. 2016. New remains of the very small cuckoo, Chambicuculus pusillus (Aves, Cuculiformes, Cuculidae) from the late Early or early Middle Eocene of Djebel Chambi, Tunisia. Palaeovertebrata. 40(1):e2. doi:10.18563/pv.40.1.e2.

Owen R. 1848. The archetype and homologies of the vertebrate skeleton. London: J. van Voorst.

Otero O, Pinton A, Mackaye HT, Likius A, Vignaud P, Brunet M. 2009. Fishes and palaeogeography of the African drainage basins: relationships between Chad and neighbouring basins throughout the Mio-Pliocene. Palaeogeogr Palaeoclimatol Palaeoecol. 274(3-4):134-139.

Pickford M. 1991a. Late Miocene anthracothere (Mammalia, Artiodactyla) from tropical africa. Compte Rendus Académie Sci Paris. 313:709-715.

Pickford M. 1991b. Revision of the Neogene Anthracotheriidae of Africa. In: Salem MJ, Busrewil MT, editors. The geology of Libya, vol. 4. New York: Academic press; p.1491-1525.

Pickford M. 2006. Sexual and individual morphometric variation in Libycosaurus (Mammalia, Anthracotheriidae) from the Maghreb and Libya. Geobios. 39(2):267-310.

Pickford M. 2008. Libycosaurus petrocchii Bonarelli, 1947, and Libycosaurus anisae (Black, 1972) (Anthracotheriidae, Mammalia): nomenclatural and geochronological implications. Ann Paléontol. 94(1):39-55. 
Ravel A, Adaci M, Bensalah M, Charruault AL, Essid EM, Khayati Ammar H, Mahboubi M, Marzougui W, Mebrouk F, Merzeraud G, Vianey-Liaud M, Tabuce R, Marivaux L. 2016. Origine et radiation initiale des chauves-souris modernes : nouvelles découvertes dans l'Éocène d'Afrique du Nord. Geodiversitas. 38:355-434.

Robinson P, Black CC. 1969. Note préliminaire sur les vertébrés fossiles du vindobonien (formation Béglia), du Bled Douarah, Governorat de Gafsa, Tunisie. Notes Serv Géologie Tunis. 31:67-70.

Robinson P, Black CC. 1974. Vertebrate faunas from the Neogene of Tunisia. Ann Geol Surv Egypt. 4:319-332.

Scherler L, Lihoreau F, Becker D. 2018. To split or not to split Anthracotherium? A phylogeny of Anthracotheriinae (Cetartiodactyla; Hippopotamoidea) and its paleobiogeographic implications. J Linn Soc. 1-24. doi :10.1093/zoolinnean/zly052

Schmidt M. 1913. Über Paarhufer des fluviomarinen Schichten des Fajum, odontographisches und osteologisches Material. Geol Paläontol Abh. 11:153-264.

Scott WB. 1940. The mammalian fauna of the White River Oligocene, part IV. Artiodactyla. Trans Am Phil Soc. 28:363-746.

Sen S. 2013. Dispersal of African mammals in Eurasia during the Cenozoic: ways and whys. Geobios 46(2): 159-172.

Sileem AH, Sallam HM, Hewaidy AGA, Gunnell GF, Miller ER. 2015. Anthracotheres (Mammalia, Artiodactyla) from the upper-most horizon of the Jebel Qatrani formation, latest Early Oligocene, Fayum depression, Egypt. Egypt J Paleontol. 15:1-11.

Simon B, Guillocheau F, Robin C, Dauteuil O, Nalpas T, Pickford M, Senut B, Lays P, Bourges P, Bez M. 2017. Deformation and sedimentary evolution of the Lake Albert Rift (Uganda, East African Rift System). Mar Pet Geol. 86:17-37.

Sweydan S, Merzeraud G, Essid EM, Marzougui W, Temani R, Ammar HK, Marivaux L, Vianey-Liaud M, Tabuce R, Adnet S. 2018 Aug. A reworked elasmobranch fauna from Tunisia providing a snapshot of Eocene-Oligocene Tethyan faunas. J Afr Earth Sci. doi:10.1016/j.jafrearsci.2018.08.008. [accessed 2018 Aug 29].

Swezey CS. 2009. Cenozoic stratigraphy of the Sahara, Northern Africa. J Afr Earth Sci. 53(3):89-121.

Swofford DL. 2002. PAUP*. Phylogenetic Analysis Using Parsimony (*and Other Methods). Sinauer Associates. Sunderland, Massachusetts.

Tabuce R. 2018. New remains of Chambius kasserinensis from the Eocene of Tunisia and evaluation of proposed affinities for Macroscelidea (Mammalia, Afrotheria). Hist Biol. 30(1-2):251-266.

Vialle N, Merzeraud G, Delmer C, Feist M, Jiquel S, Marivaux L, Ramdarshan A, Vianey-Liaud M, Essid EM, Marzougui W, et al. 2013. Discovery of an embrithopod mammal (Arsinoitherium?) in the late Eocene of Tunisia. J Afr Earth Sci. 87:86-92. 
Werdelin L. 2010. Chronology of Neogene Mammal localities. In: Werdelin L, Sanders WJ, editors. Cenozoic Mammals of Africa. Berkeley: University of California Press. p. $27-43$.

Westerhold T, Bickert T, Röhl U. 2005. Middle to late Miocene oxygen isotope stratigraphy of ODP site 1085 (SE Atlantic): new constrains on Miocene climate variability and sea-level fluctuations. Palaeogeogr Palaeoclimatol Palaeoecol. 217(34):205-222. 
Table 1. Teeth measurements of specimens from Sidi Hedri compared to mean values of some Merycopotamini species (Mean value \pm SD from Lihoreau et al. 2004, 2007, 2014 and new measurements of L. bahri from CNRD, N'djaména) 
Figure Captions

Figure 1. Geographical location of Sidi Hedri and other localities that have yielded Libycosaurus remains in Algeria and Tunisia (full black circle), position in regard of other fossiliferous localities (F1-4) from the Djebel Chambi area in Tunisia, and their stratigraphical relations.

Figure 2. Upper canine comparisons. Lingual views of (A) left upper canine of L. bahri from Toros-Ménalla (TM257-04-08, reversed), (B) left upper canine of L. anisae from Bled Douarah (T271, reversed) and, (C) right upper canine of L. algeriensis from Sidi Hedri (SHI01). (D) Compared dimensions at cervix of upper canines of Merycopotamus and Libycosaurus species.

Figure 3. New mandibular material with right P/3-M/2 from Sidi Hedri (SHI02) in (A) lingual, (B) occlusal, and (c) labial views.

Figure 4. Comparisons of occlusal pattern of lower P/4 in Merycopotamini. (A) Libycosaurus algeriensis, Sidi Hedri (SHI02). (B) Libycosaurus anisae Bled Douarah (Holotype T356G). (C) Libycosaurus bahri, Toros-Menalla (TM258-01-13). (D) Merycopotamus nanus, Potwar Plateau (AMNH 94616, reversed). (E) Merycopotamus medioximus, Potwar Plateau (HGSP14969, reversed). (F) Merycopotamus dissimilis Potwar Plateau (HGSP16418, reversed). (G) Sivameryx africanus Gebel Zelten (NHM No $\mathrm{N}^{\circ}$ reversed). (H) Afromeryx zelteni, Gebel zelten (M82233). (I) Hemimeryx blanfordi, Bugti Hills (M12026). Abbreviations: Proto ${ }^{\text {., }}$ protoconid; Ento ${ }^{\text {std }}$, entostylid;

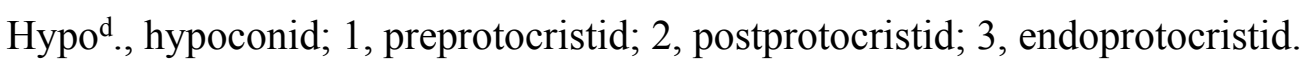


Figure 5. Left m/3 from Sidi Hedri (SHI03) in (A) labial, (B) lingual and, (C) occlusal views with scheme. Comparisons of $\mathrm{m} / 3$ dimensions of Libycosaurus species by origin. Abbreviations: Proto ${ }^{\mathrm{d}}$., protoconid; Meta $^{\mathrm{d}}$., metaconid; Hypo ${ }^{\mathrm{d}}$., hypoconid; Ento ${ }^{\mathrm{d}}$, entoconid; Hypo ${ }^{\text {ulid }}$., hypoconulid; 1, preprotocristid; 2, postprotocristid; 3, prehypocristid; 4, posthypocristid; 5, prehypocristulid; 6, posthypocristulid; 7, postectometacristid; 8 , postmetacristid; 9 , postectoentocristid; 10, preentocristid; 11 , postentocristid.

Figure 6. Phylogenetic results. Strict consensus tree of 18 equally most parsimonious trees of 1266 steps each $(\mathrm{CI}=0.30 ; \mathrm{RI}=0.64)$. Bremer indices $(>1)$ are indicated at nodes.

Figure 7. Paleobiogeographical scenario for Merycopotamini implied by new phylogeny with paleocological inferences from Lihoreau et al. (2014). The geochronological time scale is from Hilgen et al. (2012). 

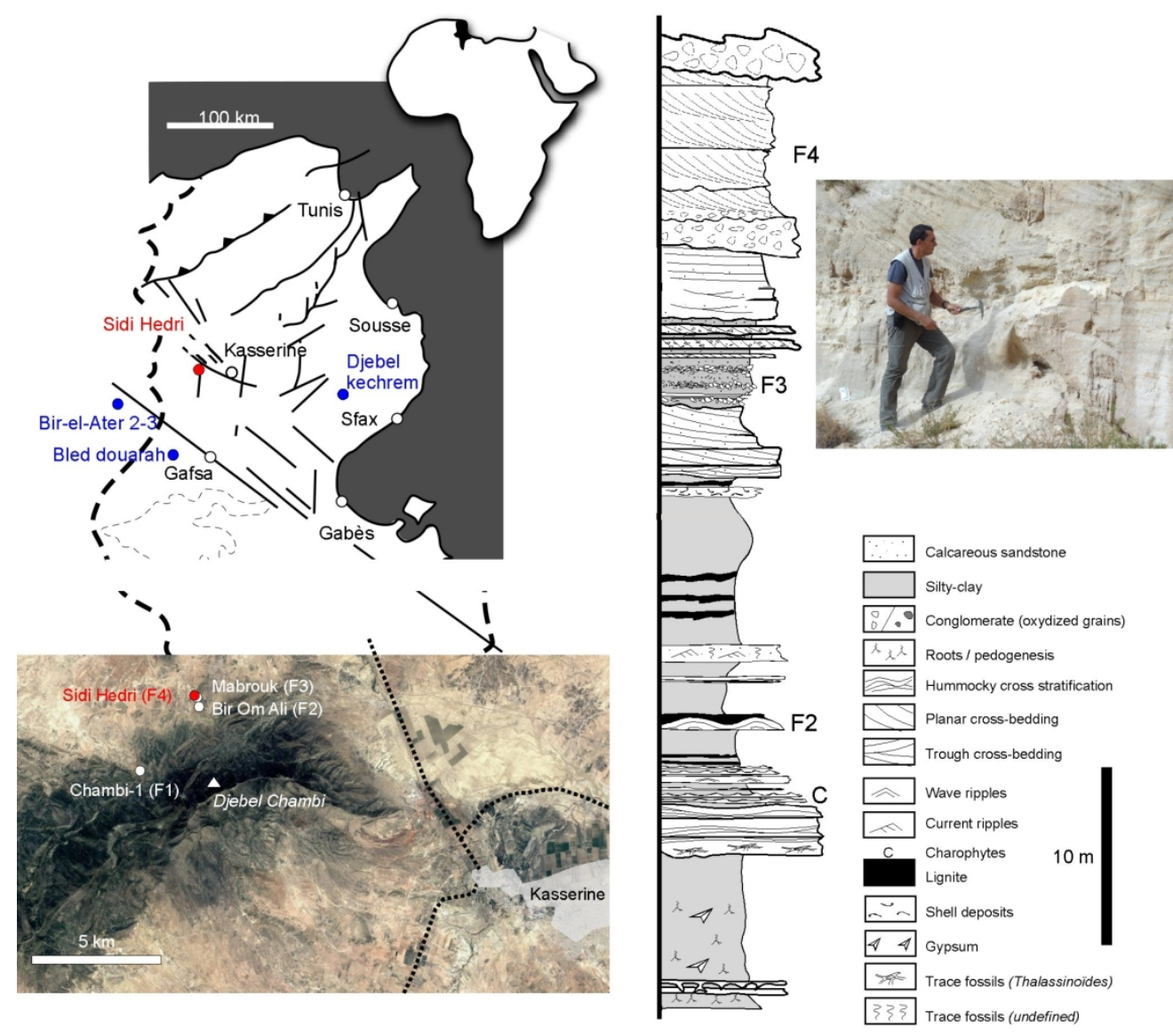

Geographical location of Sidi Hedri and other localities that have yielded Libycosaurus remains in Algeria and Tunisia (full black circle), position in regard of other fossiliferous localities (F1-4) from the Djebel Chambi area in Tunisia, and their stratigraphical relations.

$173 \times 157 \mathrm{~mm}(300 \times 300 \mathrm{DPI})$ 
1

2

3

4

5

6

7

8

9

10

11

12

13

14

15

16

17

18

19

20

21

22

23

24

25

26

27

28

29

30

31

32

33

34

35

36

37

38

39

40

41

42

43

44

45

46

47

48

49

50

51

52

53

54

55

56

57

58

59

60
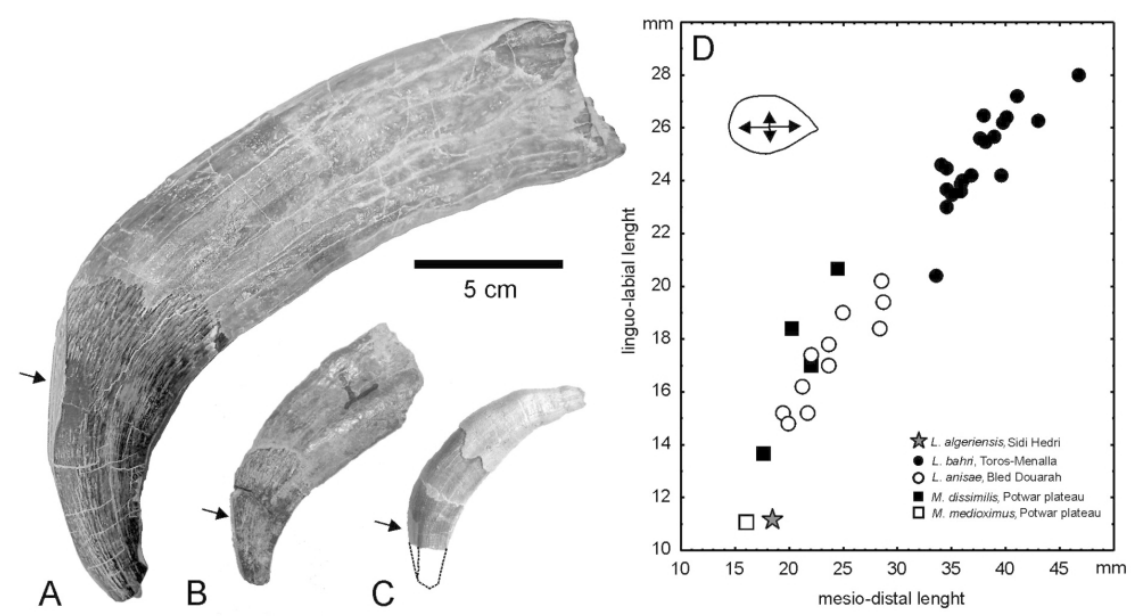

Upper canine comparisons. Lingual views of (A) left upper canine of L. bahri from Toros-Ménalla (TM257-0408, reversed), (B) left upper canine of L. anisae from Bled Douarah (T271, reversed) and, (C) right upper canine of L. algeriensis from Sidi Hedri (SHI01). (D) Compared dimensions at cervix of upper canines of Merycopotamus and Libycosaurus species.

$185 \times 92 \mathrm{~mm}(300 \times 300 \mathrm{DPI})$ 


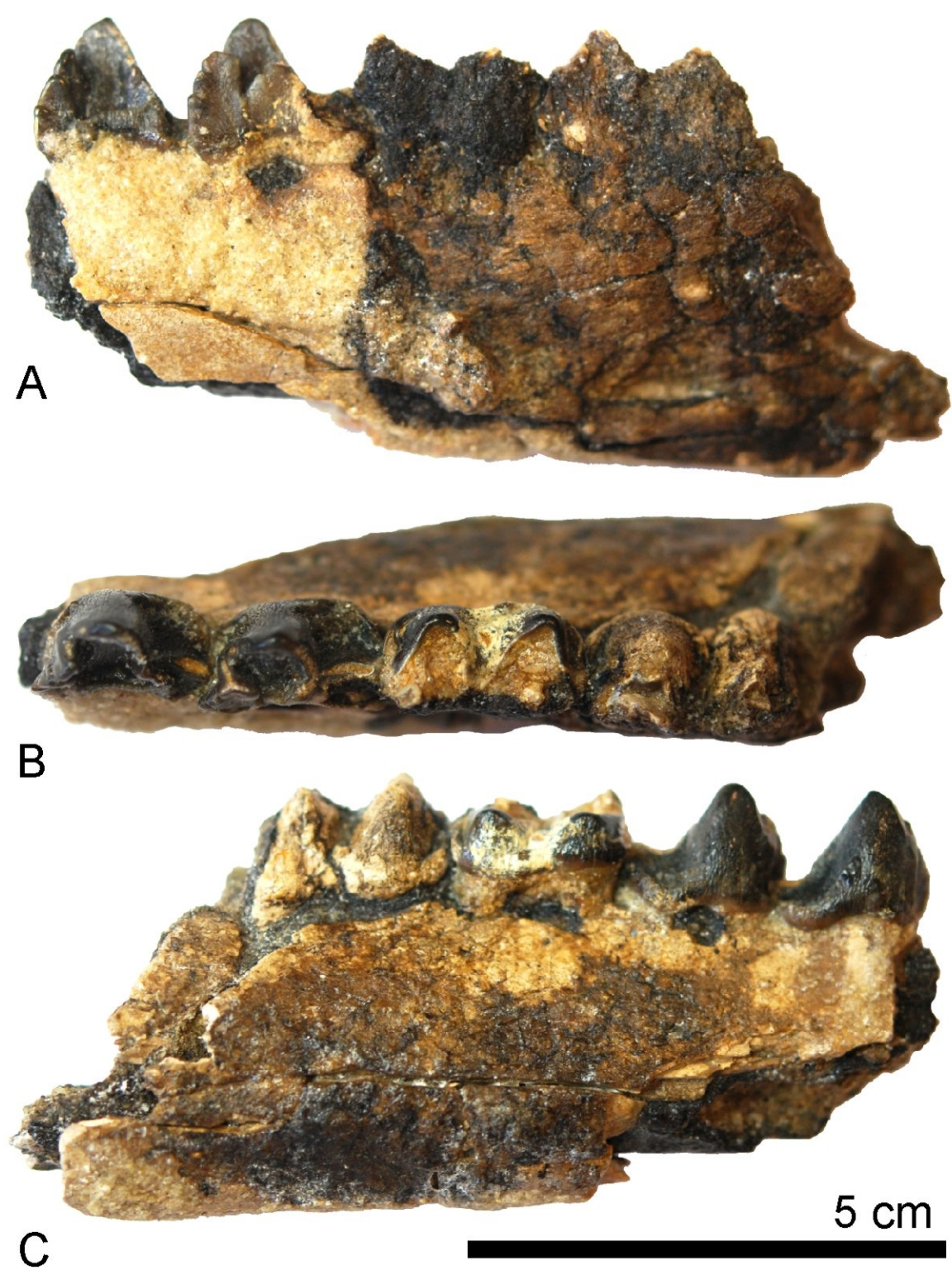

Figure 3. New mandibular material with right $\mathrm{P} / 3-\mathrm{M} / 2$ from Sidi Hedri (SHIO2) in (A) lingual, (B) occlusal, and (c) labial views.

$102 \times 137 \mathrm{~mm}(300 \times 300 \mathrm{DPI})$ 

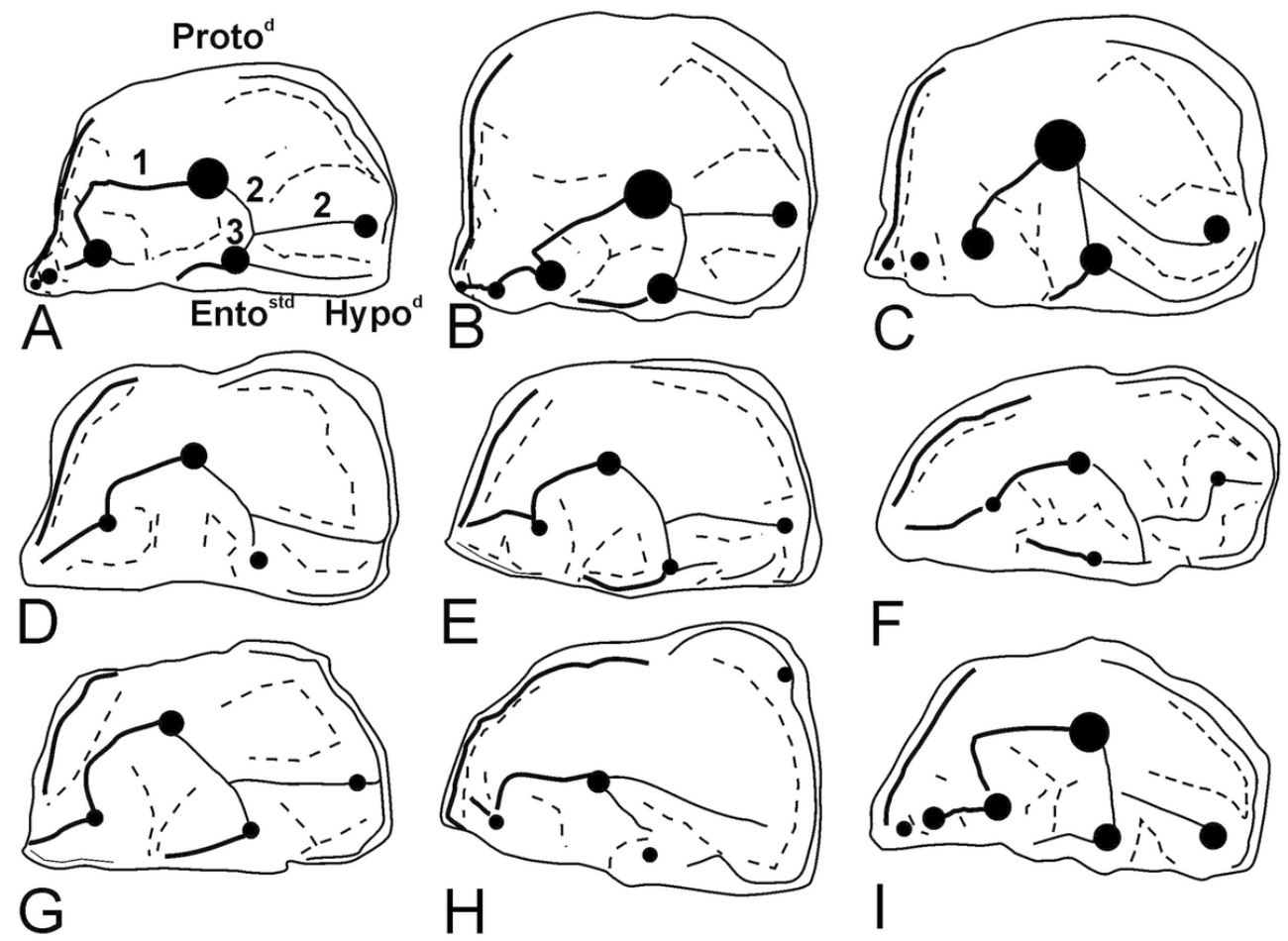

Figure 4. Comparisons of occlusal pattern of lower P/4 in Merycopotamini. (A) Libycosaurus algeriensis, Sidi Hedri (SHI02). (B) Libycosaurus anisae Bled Douarah (Holotype T356G). (C) Libycosaurus bahri, Toros-

Menalla (TM258-01-13). (D) Merycopotamus nanus, Potwar Plateau (AMNH 94616, reversed). (E)

Merycopotamus medioximus, Potwar Plateau (HGSP14969, reversed). (F) Merycopotamus dissimilis Potwar Plateau (HGSP16418, reversed). (G) Sivameryx africanus Gebel Zelten (NHM No No reversed). (H) Afromeryx zelteni, Gebel zelten (M82233). (I) Hemimeryx blanfordi, Bugti Hills (M12026). Abbreviations: Protod., protoconid; Entostd., entostylid; Hypod., hypoconid; 1, preprotocristid; 2, postprotocristid; 3, endoprotocristid.

$102 \times 75 \mathrm{~mm}(300 \times 300 \mathrm{DPI})$ 

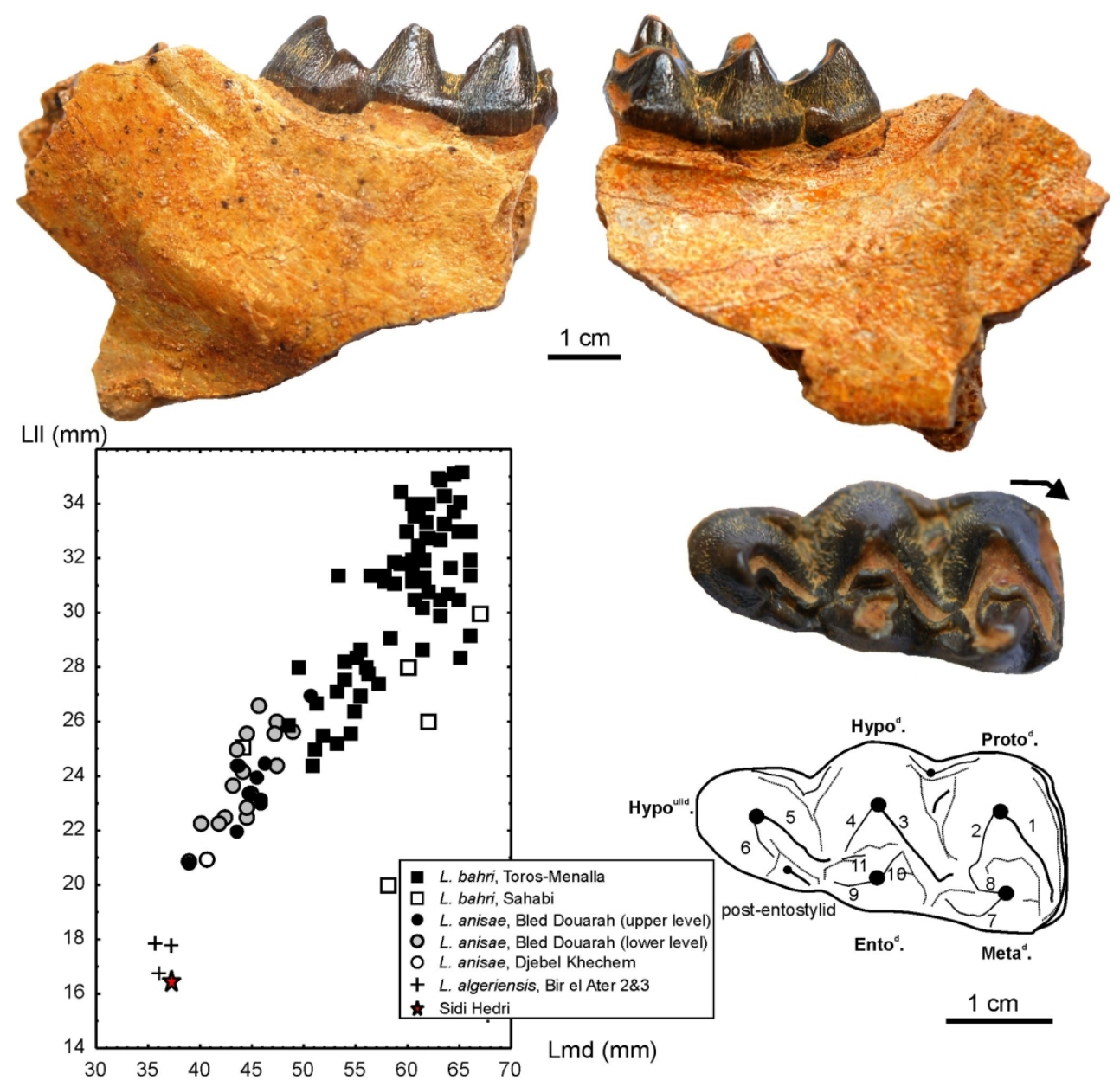

Figure 5. Left m/3 from Sidi Hedri (SHI03) in (A) labial, (B) lingual and, (C) occlusal views with scheme. Comparisons of $\mathrm{m} / 3$ dimensions of Libycosaurus species by origin.

Abbreviations: Protod., protoconid; Metad., metaconid; Hypod., hypoconid; Entod., entoconid; Hypoulid., hypoconulid; 1, preprotocristid; 2, postprotocristid; 3, prehypocristid; 4, posthypocristid; 5, prehypocristulid; 6, posthypocristulid; 7, postectometacristid; 8, postmetacristid; 9, postectoentocristid; 10, preentocristid; 11 , postentocristid.

$178 \times 179 \mathrm{~mm}(300 \times 300 \mathrm{DPI})$ 


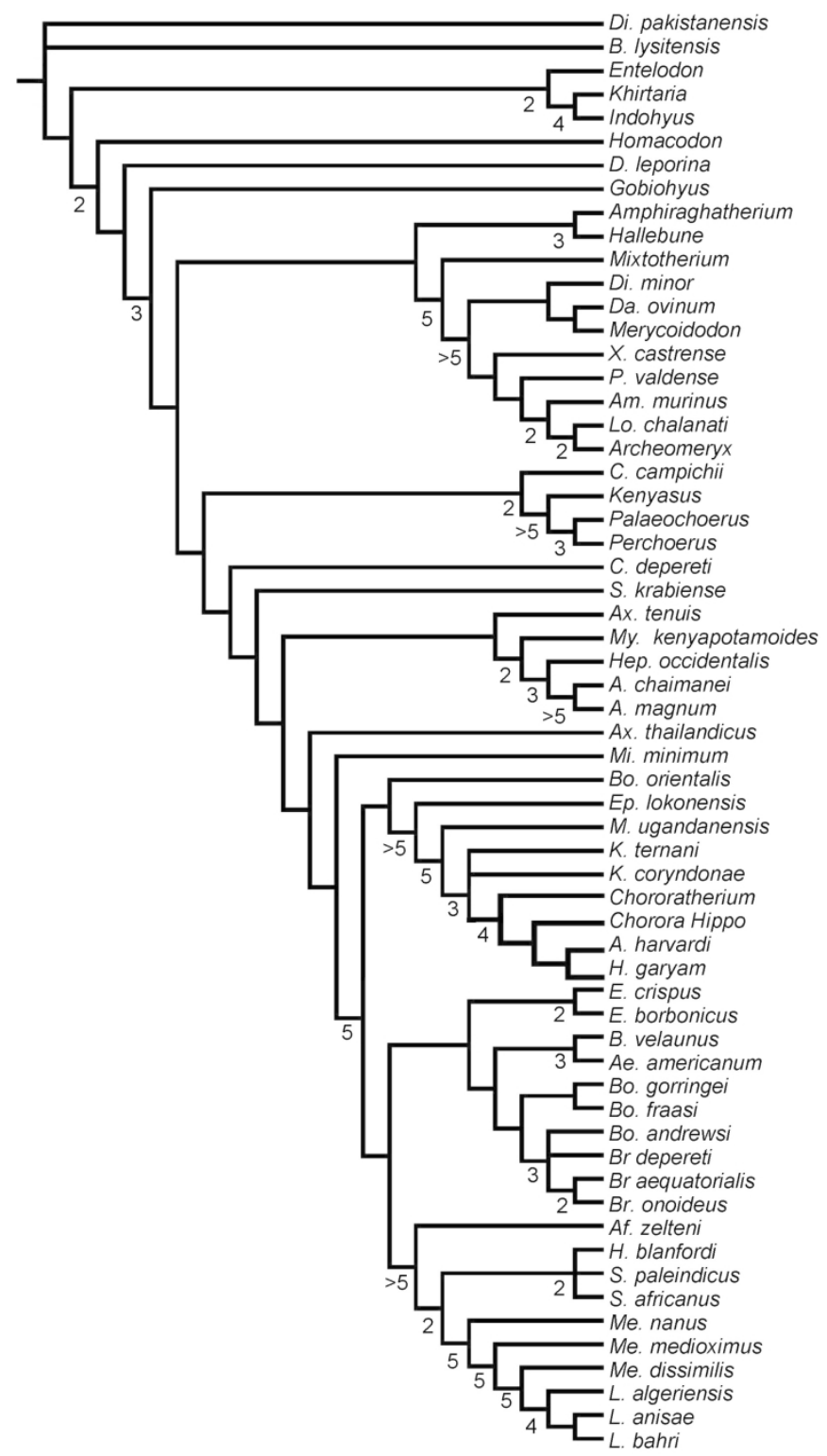

Phylogenetic results. Strict consensus tree of 18 equally most parsimonious trees of 1266 steps each $(\mathrm{CI}=0.30 ; \mathrm{RI}=0.64)$. Bremer indices $(>1)$ are indicated at nodes.

$$
165 \times 295 \mathrm{~mm}(300 \times 300 \mathrm{DPI})
$$




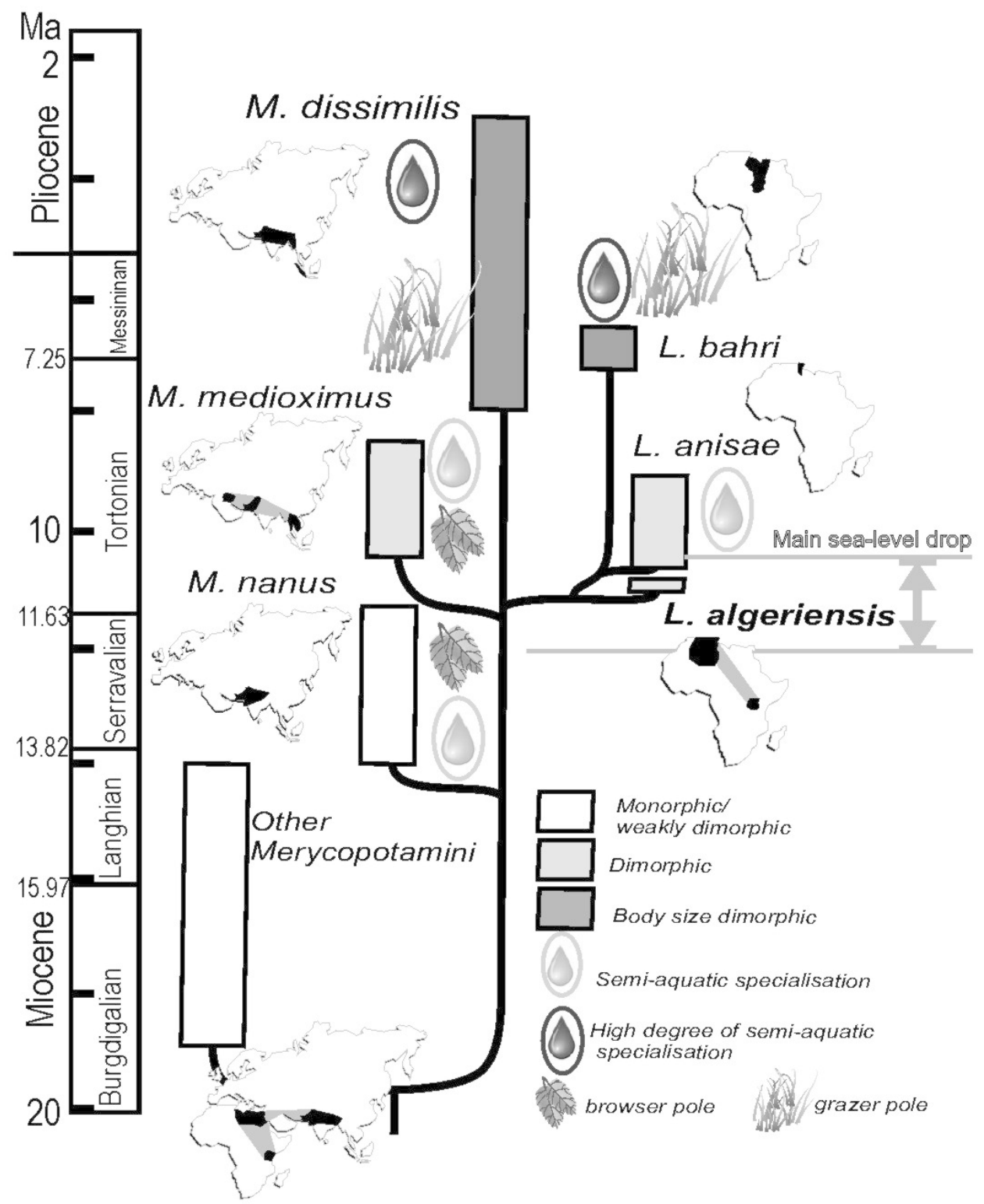

Paleobiogeographical scenario for Merycopotamini implied by new phylogeny with paleocological inferences from Lihoreau et al. (2014). The geochronological time scale is from Hilgen et al. (2012).

$$
91 \times 113 \mathrm{~mm}(300 \times 300 \text { DPI })
$$


Lihoreau et al. Supporting information

\title{
Supporting information for Lihoreau et al.
}

\author{
I List of characters for cladistics analysis \\ From Lihoreau et al. (2016), Boisserie et al. (2017), and 5 new characters $(63,80,139,156,162)$
}

\section{Anterior lower teeth}

1. Number of lower incisors:

$0 . \quad$ three

1. two

2. one

2. Lower incisor morphology:

$0 . \quad$ not caniniform

1. at least one caniniform lower incisor

3. Relative dimensions of lower incisors:

0 . all of equal size

1. one or two more developed

4. Most developed incisor:

$0 . \quad \mathrm{I} / 2$

1. $\mathrm{I} / 3$

2. $\mathrm{I} / 1$

5. Transverse section of lower incisors

crowns:

$0 . \quad$ strongly irregular

1. about rounded

6. Lower incisor cervix morphology:

$0 . \quad$ no deep indentation

1. indented cervix, indentation as long as the root diameter on the cervix

2. deep identation longer than the root diameter at cervix

7. Crown of I/1:

$0 . \quad$ straight

1. spatulate, with convex mesial and distal border

8. Presence of a median lingual pillar (lingual rib) on lower I/1:

$0 . \quad$ yes

1. no

9. Lower canine cross section at cervix:

0 subcircular

1. elliptical
10. Cristids on lower canine enamel caps:

$0 . \quad$ none

1. one distal

2. two, one mesial and one distal

3. one mesial

11. Wear on lower canine:

0. distal wear facet contact with canine

1. mesial wear facet contact with I3/

12. Groove on labial side of lower canine:

$0 . \quad$ no

1. yes

13. Groove on lingual side of lower canine:

0. no

1. yes

14. Lower canine in male:

$0 . \quad$ fang-like

1. premolariform

2. incisiform

15. Crown of lower canine in male:

0 . small near premolar size

1. at least twice the premolar size

2. prolonged growth to ever-growing

\section{Lower premolars}

16. $P / 1$ roots:

$0 . \quad$ one

1. two

17. Paraconid on lower premolars:

$0 . \quad$ no

1. yes

18. Accessory cusp on the preprotocristid of all lower premolars:

$0 . \quad$ none

1. at least one

2. at least two 
Lihoreau et al. Supporting information

19. Elongated $P / 3$ :

0 . no (shorter or equal than $\mathrm{M} / 1$ lenght)

1. yes (longer than $\mathrm{M} / 1$ lenght)

20. Three lobed $\mathbf{P} / 3$ :

$0 . \quad$ no

1. yes

21. Orientation of postprotocristid on $P / 3$ :

$0 . \quad$ distal

1. distolingual

2. distolabial

22. High cingulid on labial face of $P / 3$ :

$0 . \quad$ no

1. yes

23. Endoprotocristid on $\mathbf{P} / 3$ :

$0 . \quad$ no

1. yes

\section{Entoconid on $\mathbf{P} / 3$ :}

$0 . \quad$ never

1. at least on some specimens

25. P/3 hypoconid:

$0 . \quad$ no

1. yes

26. Preprotocristid mesiolingualy curved on

P/3:

$0 . \quad$ no

1. yes

27. Mesial accessory cusp on preprotocristid on P/3:

0. $\quad$ simple slope

1. Shoulder like structure on lateral view

2. adorned with accessory cusp

\section{Lingual contour at cervix of $P / 4$ in}

occlusal view:

$0 . \quad$ convex to straight

1. concave

\section{Labial wall on $P / 3$ or $P / 4$ :}

$0 . \quad$ convex

1. concave

30. Change in the orientation of the preprotocristid mesialy to the junction of accessory mesiolingual crest on lower premolars:

$0 . \quad$ no

1. yes
31. Orientation of the endoprotocristid on

P/4:

$0 . \quad$ absent

1. separated from postprotocristid at the protoconid apex and then straight and distolingual 2. fused with postprotocristid in part and then curved mesiolingually

\section{Distolingual cingulid on $P / 4$ in lingual}

view:

0 . forming a continuous wall lingually until the distostylid

1. reaching the level of the distal basin and keeping be shallow until the distostylid

2. reaching the level of distal basin and then being high when joigning the distostylid (distolingual notch of cingulid)

33. Presence of a preentocristid on $P / 3$ and/or on $\mathrm{P} / 4$ :

$0 . \quad$ no

1. yes

34. Mesiolingual secondary cristid on $P / 4$ (cristid connecting lingual margin and preprotocristid):

$0 . \quad$ no

1. yes

35. Labial cingulid form a $V$ (indentated) on $\mathrm{P} / 4$ before to reach the distal cingulid:

$0 . \quad$ no

1. yes

36. Marked postprotofossid on $P / 4$ :

$0 . \quad$ absent

1. present

37. Postectoprotocristid on $\mathbf{P} / 4$ :

$0 . \quad$ no

1. yes

38. Hypoconid on $\mathrm{P} / 4$ :

$0 . \quad$ no

1. yes (even incipient)

39. Ectoprotofossid on $\mathbf{P} / 4$ :

$0 . \quad$ absent

1. frequent

40. Postprotocristid position on $\mathrm{P} / 4$ (in regard of a mesiodistal midline):

0 . median or labial

1. lingual 
Lihoreau et al. Supporting information

41. Endoprotofossid on $\mathrm{P} / 4$ :

0 . reaches lingual border

1. reaches lingual cingulid wall

42. Postentocristilid on $\mathrm{P} / 4$ :

$0 . \quad$ no

1. short

2. long, which reaches cingulid distally

43. Preprotocristid direction on $P / 4$ :

0 . mesiolingual (but can be moderatly curved)

1. lingual then mesial

2. mesial then lingual

\section{Entostylid on P/4:}

$0 . \quad$ no

1. yes

2. continuous junction with cingulid without clear apex

45. Metaconid on $\mathrm{P} / 4$ :

$0 . \quad$ no

1. yes (indeed an entostylid surrounded by cingulid and not formed by cingulid)

\section{Lower molars}

\section{Premetacristid on lower molars:}

$0 . \quad$ strong

1. reduced or missing

47. Paraconid on lower molars, almost on unworn specimens:

$0 . \quad$ yes

1. no

48. Lower molar trigonid:

$0 . \quad$ equal in height with talonid

1. higher than talonid

49. Connection between premetacristid and preprotocristid on lower molars:

$0 . \quad$ yes

1. no

50. Postectoprotocristid on lower molars:

$0 . \quad$ absent

1. reduced in the valley to fully developed at least on $\mathrm{M} / 1$

\section{Postprotofossid on lower molars at least} on $\mathrm{M} / 3$ :

$0 . \quad$ no

1. yes
52. Postmetacristid on $M / 1-2$ :

0 . curving toward postprotocristid forming a transverse bridge with it

1. orientated straight toward the centre of the tooth

2. forming a rounded postmetaconulid not preferentiallyorientated

3. joins prehypocristid

53. Ectoprotofossid on lower molars:

$0 . \quad$ absent

1. present

54. Ectometafossid on lower molars:

$0 . \quad$ yes

1. no

55. Endometacristid on lower molars:

0 . no or slightly expressed much more like an enamel fold

1. present

56. Postectometacristid on lower molars:

0 . lightly marked to absent

1. always present and well-marked

57. Premetafossid on lower molars:

$0 . \quad$ present

1. absent

58. Preentocristid:

$0 . \quad$ absent

1. present

59. Preentocristid connects:

$0 . \quad$ endohypocristid

1. prehypocristid toward the cuspid apex

2. prehypocristid toward its mesial extremity

60. Postectoentocristid on lower molars:

$0 . \quad$ absent

1. present but more like a keel on cusp

2. present and well individualized from the cusp

61. Ectoentocristid:

$0 . \quad$ present

1. absent

62. Postentocristid on lower molars:

$0 . \quad$ absent

1. present

63. Postencristid mesiodistally oriented and 
Lihoreau et al. Supporting information

comprised between the posthypocristid and the entoconid (=the entoconid fold):
$0 . \quad$ no
1. yes

64. Prehypocristid dividing in two mesial arms on lower molars:
$0 . \quad$ yes
1. no

65. Prehypocristid inflated (not salient when unworn) ) in transverse valley of lower molars:

$0 . \quad$ no

1. yes (even to form a conulid)

66. Prehypocristid reaches:

0 . median part of transverse valley

1. lingual part of transverse valley

2. labial part of the transverse valley

67. Main arm of prehypocristid connects:

0 . trigonid distal walls (junction between

cristids from metaconid and protoconid)

1. postmetafossid

2. lingual margin of transverse valley

3. postmetacristid

\section{Posthypocristid joins:}

0 . nothing or distostylid

1. postentocristid

2. postectoentocristid

69. Endohypocristid on lower molars:

0 . absent

1. present

70. Posthypofossid on lower molars:

$0 . \quad$ absent

1. present

\section{Entostylid on lower molars that could} sometimes be linked to an entocristylid:

0 never

1. frequently present

\section{Ectostylid on lower molars:}

0 . no cingulid

1. a shallow and constant cingulid in front of the transverse valley

2. frequently developed cingulid in a /some stylid at least on $\mathrm{m} 1$

\section{Ectocrystilid on lower molars :}

$0 . \quad$ no

1. yes even if variable
74. Cingulid surrounding $\mathrm{m} / 3$ hypoconulid:

0 . no specimen exhibiting such extension

1. occasionally bordering the labial wall

75. Presence of one or many postentostylid on M/3:

$0 . \quad$ no

1. yes

76. Ectohypocristulid on $\mathrm{M} / 3$ :

0 . absent

1. not complete

2. present joigning the summit of hypoconulid

77. Distostylid on $\mathrm{M} / \mathbf{1}-\mathrm{M} / \mathbf{2}$ :

0 median

1. lingual

2. none

78. Mesial part of loop-like hypoconulid:

$0 . \quad$ open

1. pinched

79. Posthypocristulid:

0. complete

1. incomplete

80. Posthypocristulid incomplete due to:

0 . a groove separates the cristid in two part

1. It lacks a part or totality of the cristid

81. Entoconulid:

0 no

1. yes

Anterior upper teeth

82. Number of upper incisors:

$0 . \quad 3$

1. 2

2. none

83. Central upper incisor:

0 . morphologically similar to I2/ and/or I3/

1. peg-like, morphologically different from others

2. caniniform

84. $I 3 /$ reduced in size compared to $I 1 /$ :

0 no

1. yes

85. Upper canine morphology:

0 . strong, with circular or elliptic cross section 
1. strong and laterally compressed (blade-like)

2. premolariform

86. Canine size root:

$0 . \quad$ equivalent to slightly longer than the crown

1. at least twice the size of the crown

2. prolonged to continuous growth of root

3. prolonged and continuous growth of crown

87. Dimorphic upper canine:

$0 . \quad$ no

1. yes

Upper premolars

88. Diastem C-P1/ ou C-P/:

$0 . \quad$ yes

1. no

89. Diastem P1/-P2/:

$0 . \quad$ no

1. yes

90. Number of upper premolar:

0.4

1. 5

2. 3

\section{Distolabial crests of upper premolars} (postparacrista):

$0 . \quad$ simple

1. with a maximum of two accessory cusps

2. with more than two accessory cusps at least on one premolar

92. Number of mesial crests on P1-3/:

$0 . \quad$ one

1. two

93. Disto-lingual basin in $\mathbf{P} 2 /$ :

$0 . \quad$ yes

1. no

94. Accessory cusp on disto-lingual cingulum of P3/:

$0 . \quad$ none

1. one cingular style

2. protocone (surrounded by a cingulum)

95. Metacone on P3/:

$0 . \quad$ no

1. yes

96. $\quad P 3 /$ root pattern:

0 one mesial root, two distal root not fused
1. one mesial root and fused distal ones

97. P4/ paracone:

0 . simple with crest

1. complex with fossa

2. very complex with more fossae

98. Orientation of preparacrista on $\mathrm{P} 4$ /:

$0 . \quad$ mesial

1. labial

99. Postprotocrista on P4/:

$0 . \quad$ absent

1. present

100. Postprotocrista on P4/ joins:

0 . base of paracone

1. distostyle

2. metastyle

101. Preprotocrista on $\mathrm{P} 4$ / joins:

$0 . \quad$ mesiostyle

1. base of the paracone then mesiostyle

2. parastyle

102. Postectoprotocrista on $\mathrm{P} 4 /$ :

$0 . \quad$ absent

1. present

103. P4/ protocone:

$0 . \quad$ rounded

1. crescentic

104. In lingual view protocone of $P 4$ / is:

$0 . \quad$ displaced mesially

1. median

105. P4/ mesial margin:

$0 . \quad$ concave

1. convexe

106. Strong development of distostyle on P4/:

$0 . \quad$ no

1. yes

107. Mesial accessory cusp on $\mathrm{P} 4$ / that can be linked to mesiostyle:

$0 . \quad$ no

1. yes

108. P4/ metacone:

$0 . \quad$ absence

1. presence

109. $\mathrm{P} 4$ / paracone higher than the protocone: 
Lihoreau et al. Supporting information

0. slightly higher than protocone

1. much higher than protocone

110. P4/ endoparacrista:

$0 . \quad$ absence

1. presence

111. Distal accessory cusp on postprotocrista of P4/ that can be linked to distostyle:

$0 . \quad$ no

1. yes

Upper molars

112. Height of lingual cingulum compared to unworn protocone height on upper molars:

$0 . \quad$ one third

1. half

2. no cingulum

113. Mesio-distal ribs development of labial cusps of upper molars:

0 . almost half the molar length

1. pinched (inferior to one third of molar length)

2. enlarged (superior to half the molar length)

114. Postectoprotocrista:

$0 . \quad$ absent

1. present

115. Postprotocrista:

$0 . \quad$ present

1. absent

116. Protocone and metaconule junction on upper molars:

$0 . \quad$ none

1. premetacristule with postectoprotocrista

2. premetacristule with postprotocrista

3. postprotocrista and lingual part of metaconule

117. Premetacristule divided in two mesial arms:

$0 . \quad$ no

1. yes

118. Ectometacristule on upper molars:

$0 . \quad$ absent

1. present at least on M1/

2. not frequent and only on M2/ or M3/

119. Postmetafossule:

0. absent
1. present

120. Secondary cristule labial to metaconule eventually an endometacristule or enamel knob:

$0 . \quad$ no

1. yes

121. Distostyle on upper molars:

$0 . \quad$ yes

1. no

122. Distostyle position on upper molars levels:

$0 . \quad$ metaconule

1. metacone

123. Secondary ectometafossule lingual to ectometacristule:

$0 . \quad$ absent or very light

1. present mesially at least on M1/ linked to ectometacristule

124. Paraconule on upper molars:

$0 . \quad$ present

1. absent

125. M2/ paraconule when present:

0 . similar in size with protocone

1. smaller than protocone

126. Postparacristule extends to connect:

$0 . \quad$ none

1. base of the paracone

2. transverse valley

127. Preparacrista connects the parastyle:

0 . no, separated by a groove

1. yes, lingually

2. yes, labially

128. Endoparacrista on upper molars:

$0 . \quad$ absence

1. presence

129. Ectoparafossa on upper molars:

0. no

1. yes

130. Ectocristyle:

$0 . \quad$ frequently present

1. absent

131. Premetacrista and postparacrista connect:

$0 . \quad$ no connection

1. direct connection in a centrocrista 
Lihoreau et al. Supporting information

2. connection to mesostyle (via ectocristyle or not)

132. Endometacrista and endometacristule forming a transverse crest:

$0 . \quad$ absence

1. presence

133. Parastyle development:

$0 . \quad$ enamel knob

1. smaller or equal than mesostyle

2. larger than mesostyle

134. Premetacristule invade labial part of the transverse valley:

$0 . \quad$ no

1. yes

135. Position of metaconule on upper molar:

0 . labial side of the protocone

1. distal side of the protocone

136. M2/ metaconule:

0 . similar in size with protocone

1. smaller than protocone

137. Mesostyle on upper molars:

$0 . \quad$ no

1. yes

138. Mesostyle:

$0 . \quad$ enamel knob

1. half to the size of labial cusp

2. larger than labial cusp

139. Cingulum at the junction between postparacrista and premetacrista forming labial structure on mesostyle:

$0 . \quad$ high triangular cingulum

1. wing-like cingulum

2. low or absent cingulum

140. Division of the mesotyle on upper molar:

0 . no, one style or continuous cristae

1. two apices in unworn molars but still

connected by cristae

2. fully isolated style apices

141. Metastyle:

0 . reduced to enamel knob or absent

1. fully developed

142. Root fusion on upper molars:

0 . four roots with occasional fusion close to cervix, the root apices always remaining free
1. fully fused lingual roots

2. three roots

143. Lingual cingulum on upper molars:

$0 . \quad$ no

1. yes

2. developed in entostyle

144. Hypocone on upper molars (at least M2/:

$0 . \quad$ yes

1. no

145. Shape of M1/:

$0 . \quad$ triangular

1. quadrate

146. Shape of $\mathrm{M} 3 /$ :

$0 . \quad$ triangular

1. quadrate

147. M3/ size:

$0 . \quad$ Larger than M2/

1. equal in size with M2/

2. reduced (less than $60 \%$ )

148. Mesiolingual style on upper molar mesial cingulum:

$0 . \quad$ no

1. yes

Mandible

149. Symphysis morphology in sagittal section, ventral border:

$0 . \quad$ convex

1. straight to almost straight

2. concave

150. Symphysis morphology in sagittal section, dorsal border:

0 . convex

1. straight or almost straight

2. markedly concave

151. Diastem C-P/1:

$0 . \quad$ absent

1. present

152. Bone fusion at symphysis in adult specimens:

$0 . \quad$ no

1. yes

153. Maximal thickness of the symphysis in sagittal section: 
Lihoreau et al. Supporting information

$$
\begin{aligned}
& \text { 0. in the middle part } \\
& \text { 1. in the rostral part } \\
& \text { 2. in the nucal part }
\end{aligned}
$$

154. Symphysis extension:

0 . extends nuchally between $\mathrm{C}$ and $\mathrm{P} / 1$

1. extend nuchally between $\mathrm{P} / 1$ and $\mathrm{P} / 3$

2. extends nuchally to $\mathrm{P} / 3$

\section{Number and position of main external} foramen:

0 numerous

1. only one below the anterior part of the premolar row

2. two, one below the anterior part and the other below the posterior

156. Mandibular notch:

0 . no

1. yes, long extension behind coronoid process

2. yes, short extension below $\mathrm{m} / 3$

157. Transverse constriction of mandible at CP/1 diastema:

$0 . \quad$ no

1. yes

\section{Mandibular protuberance at the $C / P / 1$} level:

$\begin{array}{ll}0 . & \text { no } \\ 1 . & \text { yes }\end{array}$

159. $\mathrm{P} / 1-\mathrm{P} / 2$ diastema:

0 . absent

1. present

160. $P / 2-P / 3$ diastema:

0 . yes

1. no

\section{Cranium}

161. Opening of internal choanes:

0 . at M3/

1. nucal to M3/

162. Opening of main palatal foramen:

0 . at palatine-maxillary junction in front of molars to P3

1. on maxillary in front of P2-P1

2. on maxillary cranial to $\mathrm{P} 1$

\section{Enamel microstructure}

163. Enamel ornamentation: $\begin{array}{ll}0 . & \text { no } \\ 1 . & \text { yes }\end{array}$

164. Schmelzmuster composed of:

0. two layers

1. three layers

2. one layer

165. Inner radial enamel:

0 . absent

1. present

166. HSB percent of Schmelzmuster:

0 absent

1. less than $75 \%$

2. more than $76 \%$

167. Outer radial enamel:

0 . less or equal to $20 \%$

1. more than $20 \%$

168. Hsb zone:

0 . thin with bands always less than $100 \mu \mathrm{m}$

1. large (equal or more than $100 \mu \mathrm{m}$ )

169. Regular aspect (constant width):

$0 . \quad$ yes

1. no

170. HSB variable $(\mathrm{SD}>\mathbf{2 0})$ :

$0 . \quad$ no

1. yes

171. HSB angle with EDJ:

0 . $>70^{\circ}$

1. $<70$. $\circ$

172. Orientation of HSB:

0 . straight

1. bent

173. HSB definition (decussation angle and size of transition zone):

0 clear

1. blurry

174. Division of HSB:

0 . anastomosis

1. bifurcation

2. no division

175. HSB configuration:

0 . curved

1. transverse 
176. Synchronous prism undulation on horizontal section:

$0 . \quad$ no

1. yes but few

2. yes but more or equal to 4

177. IPM in inner portion:

$0 . \quad$ closed sheath

1. Inter row sheets

178. IPM in middle portion:

$0 . \quad$ closed sheath

1. Inter row sheets

2. no IPM
179. IPM in outer portion:

$0 . \quad$ closed sheath

1. no IPM

180. Prism angle with EDJ:

0 . equal or more than $60^{\circ}$

1. less than $60^{\circ}$

2. tends to diminish in the inner part

\section{Prism diameter:}

0 . mean between 3 and $3.9 \mu \mathrm{m}$

1. small diameter mean below $3 \mu \mathrm{m}$

2. large diameter mean above or equal to 4 
Lihoreau et al. Supporting information

\title{
II List of taxa included in the phylogenetic analysis.
}

\author{
Abbreviations for repository institutions \\ AMNH American Museum of Natural History, New York, USA \\ $\mathrm{ARCCH} \quad$ Authority for Research and Conservation of Cultural Heritage, Addis Ababa, Ethiopia \\ CGM Cairo Geological Museum, Cairo, Egypt \\ CNRD Centre National de la Recherche pour le Développement, Ndjamena, Chad \\ CROZ Musée Crozatier, Le Puy-en-Velay, France \\ DMR Department of Mineral Resources, Bangkok, Thailand \\ DPC Division of Fossil Primates, Duke Lemur Center, Durham, NC USA \\ FSL Collection de la Faculté de Sciences de Lyon \\ GSP Geological Survey of Pakistan, Museum of Natural History in Islamabad, Pakistan \\ MNHN Muséum National d'Histoire Naturelle, Paris, France \\ NHM Natural History Museum, London, UK \\ NMK National Museums of Kenya, Nairobi, Kenya \\ $\mathrm{PMH} \quad$ Peabody Museum, Harvard University, Cambridge, USA \\ UM Université de Montpellier, France \\ UNM Uganda National Museum, Uganda \\ UU Utrecht University, Netherland \\ SMNS Staatliches Museum für Naturkunde, Stuttgart, Germany \\ YU Department of Geology, Yangon University, Yangon, Myanmar
}


HIPPOPOTAMOIDEA Gray, 1821 sensu Gentry \& Hooker (7)

Hippopotamidae Gray, 1821

Morotochoerus ugandensis Pickford, 1998

- Temporal and geographical distribution

Early Miocene; eastern Africa

- Origin of examined material

- Moroto, Uganda (UNM)

- References: (22-24)

Kenyapotamus coryndonae Pickford, 1983

- Temporal and geographical distribution

Late Miocene; eastern Africa

- Origin of examined material

- Nakali Formation, Kenya (NMK)

- Namurumgule Formation, Samburu Hills, Kenya (NMK)

- Ngeringerowa, Ngorora Formation, Kenya (NMK)

- References: $(1,15-18)$

Kenyapotamus ternani Pickford, 1983

- Temporal and geographical distribution

middle Miocene; eastern Africa

- Origin of examined material

- Napudet, Lothidok Formation, Turkana, Kenya (NMK)

- Kipsaramon, Muruyur Bed, in the Tugen Hills, Kenya (NMK)

- Fort Ternan Beds, Nyanza rift, Kenya (NMK)

- Maboko and ngorora Formations, Kenya (NMK)

- References: (77)

Chororatherium roobii Boisserie et al. 2017

- Temporal and geographical distribution

Late Miocene; eastern Africa

- Origin of examined material

- Chorora Formation, Bechitat, Ethiopia (ARCCH)

- References: (79)

Hippopotamine from Chorora

- Temporal and geographical distribution

Late Miocene; eastern Africa

- Origin of examined material

- Recent bed of Chorora Formation, Teso Tadecho, Odakora North, and Gutosadeent, Ethiopia (ARCCH)

- References: (79)

Archaeopotamus harvardi (Coryndon, 1977)

- Temporal and geographical distribution

Late Miocene; eastern Africa

- Origin of examined material

- Nawata Formation, Lothagam, Kenya (NMK)

- References: (19-20)

Hexaprotodon garyam Boisserie et al., 2005

- Temporal and geographical distribution

Late Miocene; central Africa

- Origin of examined material

- Anthracotheriid Unit, Toros-Ménalla, Chad (CNAR) 
- References: (21)

“Anthracotheriidae” Leidy, 1869

Siamotherium krabiense Suteethorn et al., 1988

- Temporal and geographical distribution

Late middle and late Eocene; southeastern Asia

- Origin of examined material

- Krabi Basin, Thailand (DMR, cast at UM)

- References: (25-27)

Heptacodon occidentalis (Osborn and Wortman, 1894)

- Temporal and geographical distribution

early Oligocene, North America

- Origin of examined material

- South Dakota, USA (AMNH)

- References: (28-29)

Anthracotherium chaimanei Ducrocq 1999

- Temporal and geographical distribution Late Eocene, southeastern Asia

- Origin of examined material - Krabi Basin, Thailand (DMR, cast at UM)

- References: (27)

Anthracotherium magnum Cuvier, 1822

- Temporal and geographical distribution

Early late Oligocene, Europe

- Origin of examined material

- Cadibona, Italy (NHM)

- Digoin, France (cast at UM)

- Moissac, France (cast at UM)

- Phosphorites du Quercy, France (MNHN, cast at UM)

- References: (30-32)

Myaingtherium kenyapotamoides Tsubamoto et al. 2011

- Temporal and geographical distribution

Late middle Eocene, Asia

- Origin of examined material

- Pondaung formation, Myanmar (YU)

- References: (33)

Anthracokeryx tenuis Pilgrim and Cotter, 1916

- Temporal and geographical distribution

Late middle Eocene, Asia

- Origin of examined material

- Pondaung formation, Myanmar (AMNH)

- References: $(32,34)$

Anthracokeryx thailandicus Ducrocq, 1999

- Temporal and geographical distribution

Late Eocene, southeastern Asia

- Origin of examined material

- Krabi Basin, Thailand (DMR, cast at UM)

- References: $(27,35)$ 
Lihoreau et al. Supporting information

Microbunodon minimum Cuvier, 1822

- Temporal and geographical distribution Late Oligocene, Europe

- Origin of examined material - La Milloque, France (cast at UM)

- References: References: (35-36)

Bothriogenys orientalis Ducrocq, 1997

- Temporal and geographical distribution Late Eocene, southeastern Asia

- Origin of examined material - Krabi Basin, Thailand (DMR, cast at UM)

- References: $(3,27)$

Bothriogenys fraasi (Schmidt, 1913)

- Temporal and geographical distribution Early Oligocene, northern Africa

- Origin of examined material - Jebel Quatrani fm., Fayum, Egypt (SMNS, NHM)

- References: $(3,37-38)$

Bothriogenys gorringei (Andrews and Beadnell, 1902)

- Temporal and geographical distribution Early Oligocene, northern Africa

- Origin of examined material - Jebel Quatrani fm., Fayum, Egypt (AMNH, SMNS, NHM)

- References: $(3,37-38)$

Bothriogenys andrewsi (Schmidt, 1913)

- Temporal and geographical distribution Late Early Oligocene, northern Africa

- Origin of examined material

- Upper Sequence of the Jebel Qatrani Formation, Fayum Depression, Egypt (SMNS, CGM, DPC)

- References: $(3,37-38,80)$

Epirigenys lokonensis Lihoreau et al. 2015

- Temporal and geographical distribution late Early/early Late Oligocene, Kenya

- Origin of examined material - Lok 13, Lokone sandstone Formation, Turkana, Kenya (NMK)

- References: (78)

Brachyodus aequatorialis Mc Innes 1951

- Temporal and geographical distribution Early Miocene, Eastern Africa

- Origin of examined material - Rusinga, Kenya (NMK)

- References: (38-40)

Brachyodus onoideus (Gervais, 1848-52)

- Temporal and geographical distribution Early Miocene, Western Europe

- Origin of examined material

- Chilleur au bois, France (NHM, MNHN, UM) 
- References: (40)

Brachyodus depereti (Fourteau, 1918)

- Temporal and geographical distribution

Early Miocene, Northern Africa

- Origin of examined material - Moghara, Egypt (cast in NHM)

- References: (40-41)

Bothriodon velaunus (Cuvier, 1824)

- Temporal and geographical distribution Early Oligocene, Western Europe

- Origin of examined material - Ronzon, France (CROZ, NHM, UM2)

- References: (32)

Aepinacodon americanum (Leidy, 1856)

- Temporal and geographical distribution

Late Eocene-early Oligocene, Northern America

- Origin of examined material - South Dakota, USA (AMNH)

- References: $(29,32)$

Elomeryx crispus (Gervais, 1849)

- Temporal and geographical distribution

Late Eocene-early Oligocene, Europe

- Origin of examined material - Detan Dverce, Czech Republic (cast at UM)

- References: (32, 42-43)

Elomeryx borbonicus (Geais, 1934)

- Temporal and geographical distribution Late Oligocene and early Miocene, Western Europe

- Origin of examined material - Saint Henri, France (AMNH, NHM, FSL, UM)

- References: (42-45).

Afromeryx zelteni Pickford, 1991

- Temporal and geographical distribution

Early Miocene, Africa

- Origin of examined material

- Gebel Zelten, Libya (NHM)

- Baragoï, Buluk, Ombo, Nabwal Hill (NMK)

- References: (41)

Sivameryx palaeindicus (Lydekker, 1877)

- Temporal and geographical distribution

Early Miocene, Indian subcontinent

- Origin of examined material

- Sind, Pakistan (PMH, GSP)

- Kamlial fm. Potwar plateau, Pakistan (PMH, GSP)

- Bugti, Pakistan (NHM, AMNH)

- References: (46)

Sivameryx africanus (Andrews, 1914) 
Lihoreau et al. Supporting information

- Temporal and geographical distribution

Early Miocene, East and North Africa

- Origin of examined material

- Karungu, Kenya (NMK)

- Rusinga, Kenya (NMK)

- Gebel Zelten, Libye (NHM, MNHN)

- References: (41)

Hemimeryx blanfordi Lydekker, 1883

- Temporal and geographical distribution

Late Oligocene-early Miocene, Indian sub-continent

- Origin of examined material

- Sind, Lower Manchar Formation (NHM, GSP)

- Potwar plateau, Kamlial Formation, Pakistan (GSP)

- Bugti, Chitarwata Formation Pakistan (NHM, UM)

- References: (46)

Merycopotamus nanus Falconer, 1868

- Temporal and geographical distribution

Middle Miocene; Indian subcontinent

- Origin of examined material

- Potwar plateau, Chinji formation, Pakistan (HPM, NHM, AMNH)

- References: (47)

Merycopotamus medioximus Lihoreau et al. 2004

- Temporal and geographical distribution

Late Miocene; Indian subcontinent, Thailand, Iraq.

- Origin of examined material

- Pakistan (AMNH, GSP, UU)

- References: (47) Ajouter Lihoreau et al. 2004

Merycopotamus dissimilis (Falconer and Cautley, 1837)

- Temporal and geographical distribution

Late Miocene-Pliocene; Indian subcontinent

- Origin of examined material

- Pakistan, India, Myanmar, Nepal, Indonesia (AMNH, PMH, GSP, NHM)

- References: (47)

Libycosaurus algeriensis Ducrocq et al., 2001

- Temporal and geographical distribution

Late Miocene; central and northern Africa

- Origin of examined material

- Nementcha formation, Bir el Ater 2 and 3, Algeria (UO2) and Sidi Hedri, Tunisia (ONM)

- References: $(81,82)$

Libycosaurus anisae (Black, 1972)

- Temporal and geographical distribution

Late Miocene; northern Africa

- Origin of examined material

- Beglia formation, Bled Douarah and Djebel Kechrem el Artsouma (ONM)

- References: $(41,48-50)$

Libycosaurus bahri Lihoreau et al. 2014

- Temporal and geographical distribution

Late Miocene; central and northern Africa 
- Origin of examined material

- Anthracotheriid Unit, Toros-Ménalla (CNAR)

- References: $(38,41,50-52)$

SUOIDEA Gray, 1821

Palaeochoeridae Matthew, 1924

Palaeochoerus quercyi (Filhol, 1882) (=Doliochoerus quercyi)

- Temporal and geographical distribution

Late Oligocene; western Europe

- Origin of examined material

- Pech Desse, Quercy, France (UM)

- Pech de Fraysse, Quercy, France (UM)

- References: (53-54)

Tayassuidae Palmer, 18971

Perchoerus probus Leidy, 1869

- Temporal and geographical distribution

Late Eocene-Early Miocene - North America

References: (55-56)

Suidae Gray, 1821

Kenyasus rusingensisPickford 1986

- Temporal and geographical distribution Early Miocene - Africa

- Origin of examined material - Rusinga, Kenya (NMK)

- References: (55-56)

\section{RUMINANTIA}

Lophiomerycidae Janis, 1987

Lophiomeryx chalaniati Pomel, 1854

- Temporal and geographical distribution

Oligocene; Europe

- Origin of examined material

- Garouillas, France (UM)

- References: (57)

Archeomerycidae Simpson, 1945

Archeomeryx optatus Matthew and Granger, 1925

- Temporal and geographical distribution

Middle Late Eocene; Mongolia and China

- Origin of examined material

- Ula Usu, china (cast UM)

- References: (58)

DICHOBUNOIDEA Gill, 1872

Diacodexiidae Gazin, 1955

Diacodexis pakistanensis Thewissen et al. 1983

- Temporal and geographical distribution

Early or Middle Eocene; Pakistan

- Origin of examined material

- Barbora banda, Pakistan (casts UM)

- References: (59)

Bunophorus grangeri Sinclair, 1914 
Lihoreau et al. Supporting information

- Temporal and geographical distribution

Early Eocene; North america

- Origin of examined material

- $\quad$ Big Horn basin, Wyoming, USA (casts UM)

- References: (60)

Dichobunidae Turner, 1849

Dichobune leporina Cuvier, 1822

- Temporal and geographical distribution

Late Eocene; Europe

- Origin of examined material

- Escamps, Rosières and Aubrelong, France (UM)

- References: (60-61)

Homacodontidae Marsh, 1874

Homacodon vagans Marsh, 1872

- Temporal and geographical distribution

Early-middle Eocene; North America

- Origin of examined material

- Cast of specimens from the Twin Buttes, USA (UM)

- References: (60)

Helohyidae Marsh, 1877

Gobiohyus orientalis Matthew and Granger, 1925

- Temporal and geographical distribution

Middle Eocene; central and southern Asia

- Origin of examined material

- Irdin Manha, Ulan Shireh, Mongolia (AMNH)

- References: The attribution of G. orientalis to the Helohyidae follows (62-63) and (64). It is recognized that (65), notably, proposed a different interpretation, excluding Asian forms from the Helohyidae.

Raoellidae Sahni et al., 1981

Khirtharia spp corresponds to the three following species :

Khirtharia dayi Pilgrim, 1940

- Temporal and geographical distribution

Late Eocene; Indian subcontinent

- Origin of examined material

- Chorlakki, Pakistan (casts UM)

- References: (66)

Khirtharia inflata (Ranga Rao, 1972)

- Temporal and geographical distribution

Late Eocene; Indian subcontinent

- Origin of examined material

- Subattu formation, India (casts UM)

- References: (67)

Khirtharia aurea Thewissen et al. 2001

- Temporal and geographical distribution Middle Eocene; Indian subcontinent

- Origin of examined material

- Chorgali formation, Pakistan (casts UM)

- References: (68-69)

Indohyus indirae Ranga Rao, 1971

- Temporal and geographical distribution 
Late Eocene; Indian subcontinent

- References: (67)

\section{Other early cetartiodactyl families}

Cebochoeridae Lydekker, 1883

Cebochoerus campichii Pictet 1855-57

- Temporal and geographical distribution

Middle Eocene; Western Europe

- Origin of examined material

- Robiac, France (UM)

- References: $(61,70)$

\section{Choeropotamidae Owen, 1845}

Choeropotamus depereti Stehlin 1908

- Temporal and geographical distribution

Middle Eocene; Europe

- Origin of examined material

- Euzet, France (UM)

- References: (61, 70-71)

Hallebune krumbiegeli Erfurt and Sudre, 1995

- Temporal and geographical distribution

Middle Eocene; Europe

- Origin of examined material

- Geiseltal, Germany (cast UM)

- References: (61, 70-71)

Amphirhagatherium spp corresponds to the two following species :

Amphirhagatherium neumarkensis Erfurt and Haubold 1989

- Temporal and geographical distribution Middle-Late Eocene; Europe

- Origin of examined material

- Geiseltal, Germany (Cast UM)

- References: (61, 70-71)

Amphirhagatherium weigelti (Heller, 1934)

- Temporal and geographical distribution Middle-Late Eocene; Europe

- Origin of examined material

- Geiseltal, Germany (Cast UM)

- References: $(61,70-71)$

\section{Mixtotheriidae Pearson, 1927}

Mixtotherium spp. corresponds to the following species:

Mixtotherium gresslyi Rutimeyer, 1891

- Temporal and geographical distribution

Middle-Late Eocene; Europe

- Origin of examined material

- Egerkingen, Switzerland and La Defense, France (casts UM)

- References: (70)

Mixtotherium lavergnensis (Sudre, 1977)

- Temporal and geographical distribution Middle-Late Eocene; Europe

- Origin of examined material - Lavergne, France and Eclepens-gare, Switzerland

- References: (72) 
Amphimerycidae Pearson, 1927

Amphimeryx murinus (Cuvier, 1822)

- Temporal and geographical distribution

Late Eocene; Europe

- Origin of examined material

- Escamps, Rosières 2 and St Néboule, France (casts UM)

- References: $(61,70,72)$

Anoplotheriidae Bonaparte, 1850

Diplobune minor (Filhol, 1877)

- Temporal and geographical distribution

Late Eocene-early Oligocene; Europe

- Origin of examined material

- Itardies, France (UM)

- References: (73)

Dacrytherium ovinum Owen, 1857

- Temporal and geographical distribution Late Eocene; Europe

- Origin of examined material - Fons and Euzet, France (UM)

- References: $(70,72)$

Xiphodontidae Flower, 1884

Xiphodon castrensis Kowalesky, 1873

- Temporal and geographical distribution Late Eocene; Europe

- Origin of examined material

- Robiac and Le Bretou, France (UM)

- References: $(70,72)$

Cainotheriidae Camp and Van der Hoof, 1940

Paroxacron valdense (Stehlin, 1906)

- Temporal and geographical distribution Late Eocene-Early Oligocene; Europe

- Origin of examined material

- References: $(70,72)$

- Escamps, France (UM)

Entelodontidae Lydekker, 1883

Entelodon spp corresponds to the two following species:

Entelodon deguilhemi Repelin, 1919

- Temporal and geographical distribution

Early Oligocene; Europe

- Origin of examined material

- Villebramar and Quercy, France (cast UM2)

- References: (74)

Entelodon magnum (Aymard, 1846)

- Temporal and geographical distribution

Early Oligocene; Europe

- Origin of examined material

- Ronzon and Quercy, France

- References: (74) 
Merycoidodontidae Lydekker, 1883

Merycoidodon sp

- Temporal and geographical distribution

Oligocene; North America

- Origin of examined material

- $\quad$ Big Badland, South Dakota, USA (UM2)

- References: (75) 
Lihoreau et al. Supporting information

\section{Matrix of 181 characters and 61 taxa}

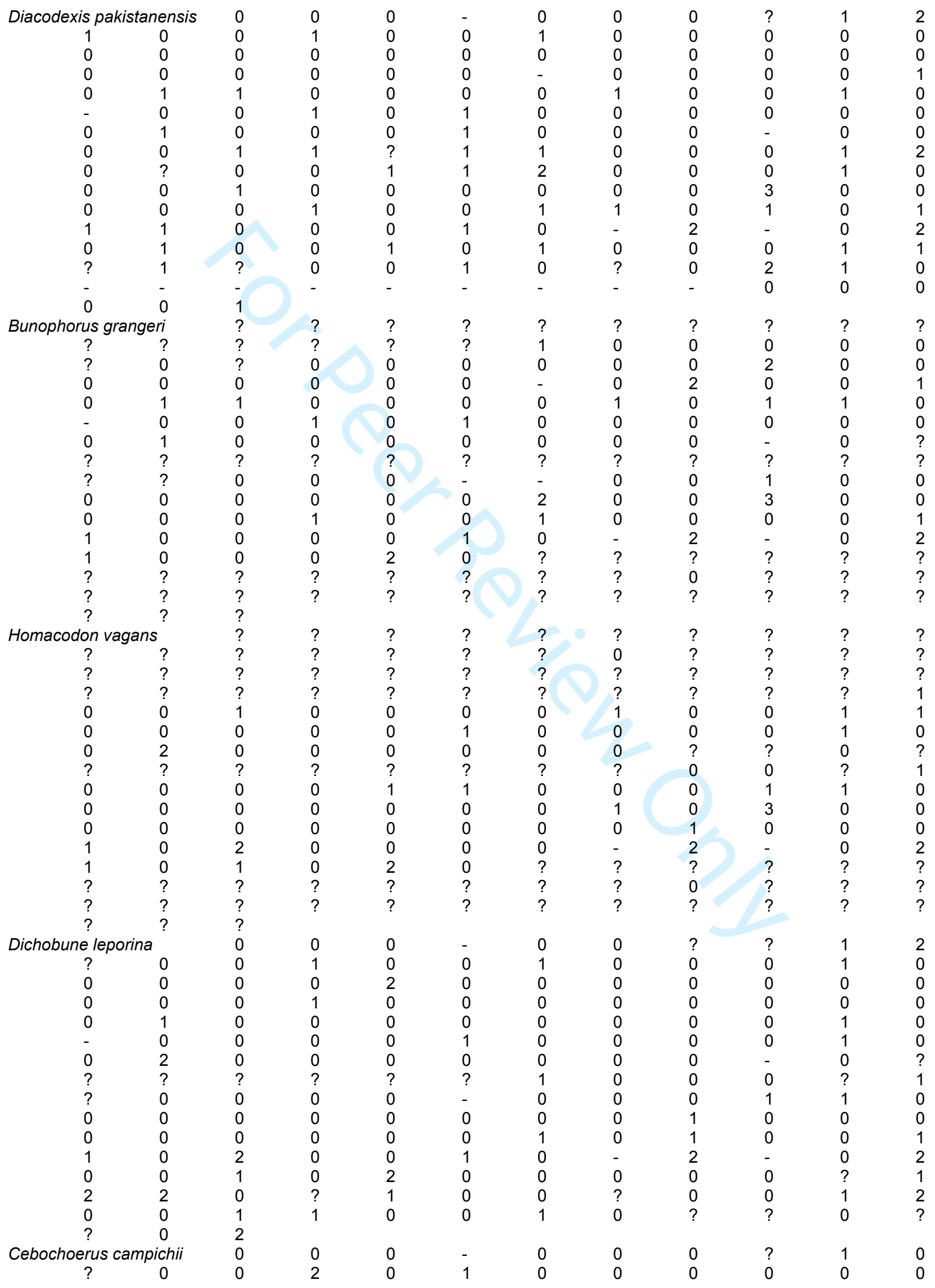




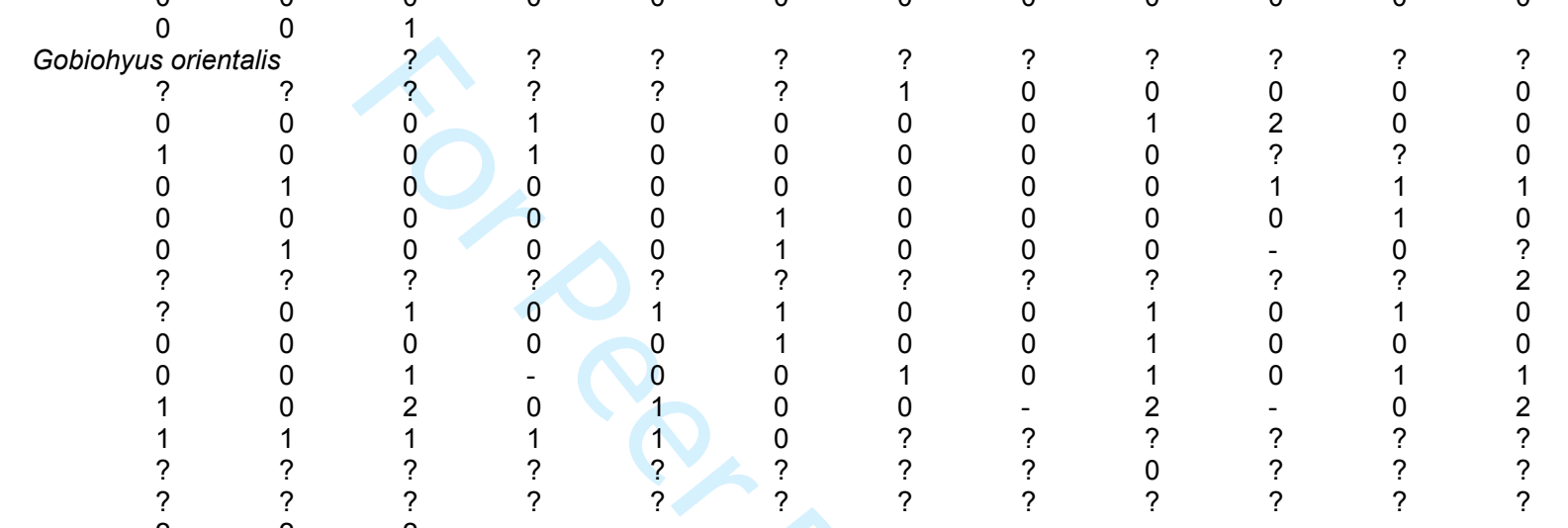




$\begin{array}{cccccccccccc}0 & 0 & 0 & 0 & 0 & 2 & 0 & 0 & 0 & - & 0 & 0 \\ 0 & 0 & 1 & ? & ? & 0 & 1 & 0 & 0 & 0 & 1 & 0 \\ 0 & ? & 1 & 0 & ? & ? & ? & ? & 1 & 0 & ? & ? \\ ? & 0 & 0 & 0 & 0 & 0 & 0 & 1 & 0 & 1 & 1 & 1 \\ 0 & 0 & 0 & 1 & 0 & 0 & 1 & 1 & 1 & 0 & 1 & 0 \\ 2 & 0 & 2 & 0 & 1 & 0 & 1 & 1 & 2 & 0 & 0 & ? \\ ? & 1 & 1 & 1 & 0 & 0 & 0 & ? & 1 & 0 & 2 & 1 \\ ? & 1 & 1 & 0 & 1 & 0 & 0 & 0 & 1 & ? & ? & ? \\ ? & ? & ? & ? & ? & ? & ? & ? & ? & ? & ? & ? \\ ? & ? & ? & & & & & & & & & \\ \text { Anthracokeryx thailandicus } & ? & ? & ? & ? & ? & ? & ? & ? & ? & ? \\ ? & ? & ? & ? & ? & 0 & 0 & 0 & 0 & 0 & 0 & 0 \\ 0 & 0 & 0 & 0 & 0 & 0 & 0 & 0 & 1 & 1 & 0 & 0 \\ 0 & 1 & 0 & 0 & 0 & 0 & 0 & 0 & 0 & 0 & 0 & 0 \\ 1 & 0 & 0 & 0 & 0 & 0 & 0 & 0 & 1 & 1 & 0 & 1 \\ 2 & 1 & 0 & 0 & 0 & 1 & 0 & 0 & 0 & 0 & 0 & 0 \\ 0 & 1 & 0 & 0 & 0 & 2 & 0 & 0 & 0 & - & 0 & ? \\ ? & ? & ? & ? & ? & ? & ? & ? & ? & ? & ? & 0 \\ 0 & ? & 1 & 0 & 1 & 0 & 0 & 0 & 1 & 0 & 0 & 0 \\ 0 & 0 & 0 & 0 & 0 & ? & 0 & 0 & 0 & 2 & 1 & ? \\ 0 & 0 & 0 & 1 & 0 & 0 & 1 & 2 & 1 & 0 & 1 & 0 \\ 2 & 0 & 1 & 0 & 1 & 0 & 1 & 1 & 0 & 0 & 1 & 0 \\ 1 & 1 & 1 & 1 & 0 & 0 & 0 & 0 & 1 & 0 & 2 & 1 \\ 2 & ? & 1 & 0 & 1 & 1 & 0 & 0 & 1 & ? & ? & ? \\ ? & ? & ? & ? & ? & ? & ? & ? & ? & ? & ? & ? \\ ?\end{array}$

Microbunodon minimum

$\begin{array}{lllllllll}0 & 0 & - & 0 & 0 & 0 & 0 & 1 & 1 \\ 0 & 0 & 0 & 0 & 0 & 1 & 0 & 1 & 0 \\ 0 & 0 & 0 & 0 & 0 & 1 & 1 & 0 & 0 \\ 0 & 0 & 0 & 0 & 1 & 0 & 1 & 0 & 0 \\ 0 & 0 & 0 & 0 & 0 & 1 & 1 & 0 & 1 \\ 0 & 0 & 1 & 0 & 0 & 0 & 0 & 0 & 0 \\ 0 & 0 & 2 & 0 & 0 & 0 & - & 0 & 0 \\ 3 & 1 & 1 & 0 & 0 & 0 & 0 & 1 & 0 \\ 1 & 1 & 0 & 0 & 0 & 1 & 0 & 1 & 0 \\ 0 & 0 & 0 & 1 & 0 & 0 & 2 & 0 & 0 \\ 1 & 0 & 0 & 1 & 2 & 1 & 0 & 1 & 0 \\ 0 & 1 & 0 & 1 & 1 & 0 & 0 & 1 & 0 \\ 1 & 0 & 0 & 0 & 1 & 1 & 1 & 2 & 1 \\ 0 & 1 & 1 & 0 & 0 & 1 & 0 & 0 & 2 \\ 0 & 0 & 0 & 0 & 0 & 0 & 0 & 0 & 0\end{array}$

\section{Heptacodon occidentalis}

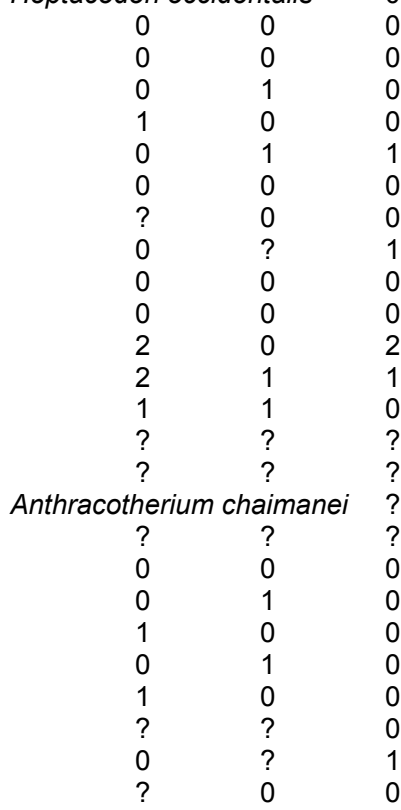

$\begin{array}{lllllllll}0 & 0 & - & ? & ? & ? & ? & 1 & 1 \\ 0 & 1 & 0 & 0 & 0 & 0 & 0 & 2 & 0 \\ 0 & 0 & 0 & 0 & 0 & 1 & 0 & 0 & 0 \\ 1 & 0 & 0 & 0 & 0 & 0 & ? & 0 & 1 \\ 0 & 0 & 0 & 0 & 0 & 1 & 1 & 0 & 1 \\ 1 & 0 & 1 & 0 & 0 & 0 & 1 & 1 & 0 \\ 0 & 0 & 0 & 0 & 0 & 0 & - & 0 & 0 \\ 1 & 1 & 1 & 0 & 0 & 0 & 0 & 1 & 1 \\ 1 & 1 & 1 & 0 & 1 & 1 & 0 & 0 & 0 \\ 0 & 0 & 0 & 0 & 1 & 0 & 1 & 0 & 1 \\ 1 & 1 & 0 & 1 & 1 & 1 & 0 & 1 & 0 \\ 0 & 1 & 0 & 1 & 2 & 0 & 0 & 1 & ? \\ 1 & 0 & 1 & 0 & ? & 0 & 1 & 2 & 1 \\ 0 & 0 & 1 & ? & 0 & 1 & ? & ? & ? \\ ? & ? & ? & ? & ? & ? & ? & ? & ?\end{array}$

$\begin{array}{lllllllll}0 & 1 & 0 & 0 & 1 & 0 & 1 & ? & ? \\ ? & ? & ? & 0 & 0 & ? & 0 & 0 & 0 \\ 0 & 0 & 0 & 0 & 0 & 1 & 0 & 0 & 1 \\ 1 & 0 & 0 & 1 & 0 & 0 & 0 & 0 & 0 \\ 1 & 1 & 0 & 0 & 0 & 1 & 1 & 0 & 1 \\ 1 & 0 & 0 & 1 & 0 & 0 & 1 & 1 & 1 \\ 0 & 1 & 1 & 0 & 0 & 0 & - & 1 & ? \\ 1 & 1 & 0 & 1 & 0 & 0 & 0 & 1 & 1 \\ 1 & 1 & 1 & 0 & 1 & 1 & 0 & 0 & 0 \\ 0 & 0 & 0 & 0 & 1 & 0 & 1 & 1 & 1\end{array}$




$\begin{array}{cccccccccccc}0 & 1 & 0 & 1 & 1 & 0 & 1 & 2 & 1 & 0 & 1 & 0 \\ 2 & 0 & 1 & 0 & 1 & 0 & 1 & 1 & 0 & 0 & 1 & 0 \\ 2 & 1 & 1 & 1 & 0 & 1 & ? & ? & ? & ? & ? & ? \\ ? & ? & ? & ? & ? & 1 & 0 & 0 & 1 & ? & ? & ? \\ ? & ? & ? & ? & ? & ? & ? & ? & ? & ? & ? & ? \\ ? & ? & ? & & & & & ? & & \\ \text { Anthracotherium magnum } & 0 & 0 & 1 & 0 & 0 & 1 & 0 & 0 & 0 & 0 \\ 0 & 0 & 0 & 0 & 1 & 0 & 0 & 0 & 0 & 0 & 0 & 0 \\ 0 & 0 & 0 & 0 & 0 & 0 & 0 & 0 & 1 & 0 & 0 & 1 \\ 0 & 1 & 0 & 1 & 0 & 0 & 1 & 0 & 0 & 0 & 0 & 0 \\ 1 & 0 & 0 & 1 & 1 & 0 & 0 & 0 & 1 & 1 & 0 & 1 \\ 0 & 2 & 0 & 1 & 0 & 0 & 1 & 0 & 0 & ? & 1 & 1 \\ 0 & 0 & 0 & 0 & 1 & 2 & 0 & 0 & 0 & - & 1 & 0 \\ 0 & 0 & 0 & 1 & ? & 1 & 1 & 0 & 0 & 0 & 1 & 1 \\ 0 & 1 & 1 & 1 & 1 & 1 & 1 & 1 & ? & 0 & 0 & 0 \\ 0 & 0 & 0 & 0 & 0 & 0 & 0 & 1 & 0 & 1 & 1 & 1 \\ 0 & 1 & 0 & ? & 1 & 0 & 1 & 2 & 1 & 0 & 1 & 0 \\ 2 & 0 & 2 & 0 & 1 & 0 & 1 & 1 & 0 & 0 & 1 & 0 \\ 2 & 1 & 1 & 1 & 0 & 1 & 0 & 0 & 0 & 1 & 0 & 1 \\ 2 & 0 & 0 & 0 & 1 & 1 & 0 & ? & 1 & 0 & 0 & 2 \\ 0 & 0 & 0 & 0 & 0 & 0 & 0 & 0 & 1 & 2 & 0 & 0\end{array}$

Myaingtherium kenyapotamoides

$\begin{array}{llllllll}0 & 0 & - & 0 & 0 & 0 & ? & 0 \\ ? & 1 & 1 & 0 & 0 & 0 & 0 & 0 \\ 0 & 0 & 0 & 0 & 0 & 1 & ? & 0 \\ 1 & 0 & 0 & 0 & 0 & 0 & 0 & 0 \\ 1 & 1 & 0 & 0 & 0 & 0 & 1 & 1 \\ 0 & 0 & 1 & 0 & 0 & 0 & 0 & 1 \\ 0 & 1 & 2 & 0 & 0 & 0 & - & 1 \\ ? & ? & ? & ? & ? & ? & ? & ? \\ 0 & 1 & 0 & 0 & 1 & 1 & 0 & 0 \\ 0 & 0 & ? & 2 & 1 & 0 & 1 & 1 \\ 0 & 0 & 0 & 1 & 1 & 0 & 0 & 1 \\ 0 & 1 & 0 & 1 & 0 & 2 & - & 0 \\ 1 & 0 & 1 & ? & ? & 1 & 0 & ? \\ 0 & 0 & 1 & ? & ? & 1 & ? & ? \\ ? & ? & ? & ? & ? & ? & ? & ?\end{array}$

\section{Bothriogenys orientalis}

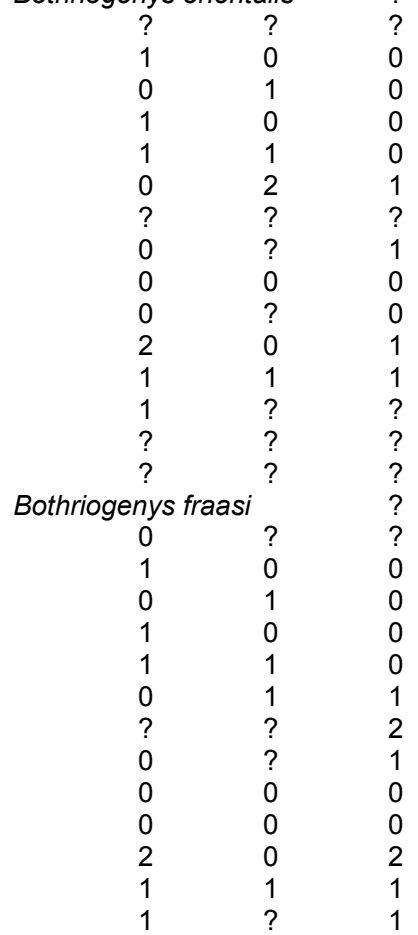

$\begin{array}{lllllll}? & ? & ? & ? & ? & ? & ? \\ 0 & 0 & 0 & 0 & 0 & 2 & 0 \\ 1 & 1 & 1 & 1 & 1 & 0 & 1 \\ 0 & 0 & 0 & 0 & 1 & 0 & 0 \\ 0 & 1 & 0 & 1 & 1 & 0 & 1 \\ 1 & 0 & 0 & 0 & 1 & 0 & 1 \\ 1 & 1 & 0 & 0 & - & 0 & ? \\ 0 & 0 & 0 & 0 & ? & 0 & 0 \\ 0 & 0 & 0 & 1 & 1 & 0 & 1 \\ 0 & 0 & 1 & 0 & 1 & 1 & 1 \\ 0 & 1 & 1 & 1 & 0 & 1 & 0 \\ 0 & 1 & 1 & 0 & 0 & 0 & 0 \\ 0 & 1 & 0 & 1 & 0 & 2 & 1 \\ 1 & 1 & 0 & 1 & ? & ? & ? \\ ? & ? & ? & ? & ? & ? & ?\end{array}$




\begin{tabular}{|c|c|c|c|c|c|c|c|c|c|c|c|}
\hline$?$ & ? & $?$ & ? & ? & ? & ? & ? & ? & ? & ? & ? \\
\hline \multicolumn{2}{|c|}{ Bothriogenys gorringei } & $?$ & 0 & 0 & ? & 0 & 0 & 1 & 1 & 1 & 2 \\
\hline 0 & 0 & 0 & 1 & 0 & 0 & 0 & 0 & 0 & 0 & 0 & 0 \\
\hline 1 & 0 & 0 & 1 & 2 & 1 & 1 & 1 & 2 & 1 & 0 & 1 \\
\hline 0 & 1 & 0 & 0 & 0 & 0 & ? & 0 & 0 & 1 & 0 & 1 \\
\hline 1 & 0 & 0 & 0 & 0 & 0 & 0 & 1 & ? & 1 & 0 & 1 \\
\hline 2 & 2 & 0 & 0 & 0 & 1 & 0 & 0 & 0 & ? & 0 & 1 \\
\hline 1 & 1 & 1 & 1 & 0 & 0 & 1 & 0 & 0 & - & 0 & 0 \\
\hline 0 & 0 & $?$ & ? & ? & ? & ? & ? & ? & ? & ? & ? \\
\hline$?$ & ? & $i$ & 1 & 1 & 0 & 1 & 0 & $i$ & 0 & 0 & 0 \\
\hline 0 & 0 & 0 & 0 & 0 & 1 & 1 & 1 & 0 & ? & 1 & 1 \\
\hline 0 & 0 & 0 & 1 & 0 & 0 & 1 & 1 & 1 & 0 & 1 & 0 \\
\hline 2 & 0 & 2 & 0 & 1 & 0 & 1 & 1 & 0 & 0 & 1 & 0 \\
\hline 1 & 1 & 1 & 1 & 0 & 0 & 0 & 2 & 1 & 0 & 2 & 1 \\
\hline 2 & 1 & 1 & 0 & 1 & 0 & 1 & 0 & 1 & 1 & 1 & 1 \\
\hline 0 & 0 & 0 & 0 & 1 & 1 & 0 & 2 & ? & ? & 0 & 1 \\
\hline$?$ & 1 & 0 & & & & & & & & & \\
\hline \multicolumn{2}{|c|}{ Bothriogenys andrewsi } & $?$ & ? & ? & ? & 0 & 0 & 1 & 1 & ? & \\
\hline$?$ & $?$ & $?$ & ? & ? & ? & 0 & 0 & 0 & 0 & 0 & 0 \\
\hline$i$ & 0 & 0 & 1 & 1 & 0 & 0 & 0 & 2 & 1 & 0 & 1 \\
\hline 0 & 1 & 0 & ? & 0 & 0 & 0 & 0 & 0 & 2 & 0 & 0 \\
\hline 1 & 0 & 1 & 0 & 0 & 0 & 0 & 1 & 0 & 0 & 0 & 1 \\
\hline 1 & 2 & 1 & 0 & 0 & 1 & 0 & 0 & 1 & 2 & 0 & 0 \\
\hline 0 & 1 & 1 & 1 & 0 & 0 & 1 & 0 & 0 & - & 0 & 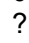 \\
\hline$?$ & ? & $?$ & $?$ & ? & ? & ? & ? & ? & ? & ? & ? \\
\hline$?$ & $?$ & 1 & 1 & 1 & 0 & 0 & 0 & 1 & 1 & 0 & 0 \\
\hline 0 & 0 & 0 & 0 & 0 & 0 & 1 & 1 & ? & ? & ? & 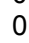 \\
\hline 0 & ? & 0 & 1 & 0 & 0 & ? & ? & 1 & ? & 1 & 0 \\
\hline 2 & $?$ & 2 & $?$ & 1 & 0 & 1 & 1 & 2 & 0 & 1 & ? \\
\hline 1 & 1 & 1 & ? & ? & 0 & ? & ? & ? & ? & ? & ? \\
\hline$?$ & ? & $?$ & $?$ & ? & ? & ? & $?$ & 1 & ? & ? & $?$ \\
\hline$?$ & ? & $?$ & ? & ? & ? & ? & ? & ? & ? & ? & ? \\
\hline ? & ? & ? & & & & & & & & & \\
\hline \multicolumn{2}{|c|}{ Brachyodus aequatorialis } & $i$ & 1 & 1 & 1 & 0 & ? & 1 & ? & 1 & \\
\hline 0 & $?$ & $?$ & 1 & 0 & 0 & 0 & 0 & 0 & 0 & 1 & 0 \\
\hline 1 & 0 & 0 & 1 & 1 & 1 & 1 & 0 & 2 & 1 & 1 & ? \\
\hline 0 & 1 & 0 & 0 & 0 & 0 & 0 & 0 & 0 & 2 & 0 & 1 \\
\hline 1 & 0 & 1 & 0 & 0 & 0 & 0 & 1 & 0 & 1 & 1 & 1 \\
\hline 1 & 2 & 0 & 0 & 0 & 0 & 0 & 0 & ? & 2 & 0 & 0 \\
\hline 0 & 1 & 1 & 1 & 0 & 1 & 1 & 0 & 0 & - & 0 & 1 \\
\hline 2 & 1 & 2 & 0 & 0 & 0 & 0 & 0 & 0 & ? & 0 & 0 \\
\hline 0 & ? & 1 & 1 & 1 & 0 & 1 & 0 & 1 & 0 & 0 & 0 \\
\hline 0 & 0 & 0 & 0 & 1 & 0 & 1 & 1 & 1 & 0 & 0 & 1 \\
\hline 0 & 0 & 0 & 1 & 0 & 0 & 1 & 2 & 1 & 0 & 1 & 0 \\
\hline 2 & 0 & 2 & 0 & 1 & 0 & 1 & 1 & 2 & 0 & 1 & 0 \\
\hline 1 & 1 & 1 & 1 & 1 & 0 & 0 & 1 & 1 & 1 & 2 & 0 \\
\hline 1 & 1 & 1 & 0 & 0 & 1 & 1 & 1 & 1 & ? & ? & 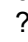 \\
\hline$?$ & ? & $?$ & ? & $?$ & ? & $?$ & $?$ & ? & ? & ? & ? \\
\hline \multirow{2}{*}{\multicolumn{2}{|c|}{ Brachyodus onoideus }} & $?$ & & & & & & & & & \\
\hline & & 1 & 1 & 1 & 1 & 0 & 0 & 1 & 1 & 1 & 2 \\
\hline 0 & 0 & 0 & 1 & 0 & 0 & 0 & 0 & 0 & 0 & 0 & \\
\hline 1 & 0 & 0 & 1 & 1 & 0 & 1 & 0 & 2 & 1 & 0 & 1 \\
\hline 0 & 1 & 0 & 0 & 0 & 0 & 0 & 0 & 0 & 2 & 0 & 1 \\
\hline 1 & 0 & 1 & 0 & 0 & 0 & 0 & 1 & 0 & 1 & 1 & 1 \\
\hline 1 & 2 & 1 & 0 & 0 & 1 & 0 & 1 & 1 & 2 & 0 & 0 \\
\hline 0 & 0 & 1 & 1 & 0 & 0 & 1 & 0 & 0 & - & 0 & 1 \\
\hline 2 & 1 & 2 & 0 & 0 & 0 & 0 & 0 & 0 & 1 & 0 & c \\
\hline 0 & ? & 1 & 1 & 1 & 0 & 1 & 0 & 1 & 0 & 0 & 0 \\
\hline 0 & 0 & 0 & 0 & 1 & 0 & 1 & 1 & 1 & 0 & 0 & 0 \\
\hline 0 & 0 & 0 & 1 & 0 & 0 & 1 & 2 & 1 & 0 & 1 & c \\
\hline 2 & 0 & 2 & 0 & 1 & 0 & 1 & 1 & 2 & 0 & 1 & ( \\
\hline 1 & 1 & 1 & 1 & $?$ & 0 & 0 & 1 & 1 & 1 & 2 & \\
\hline 1 & 1 & 1 & 0 & 0 & 1 & 1 & 2 & 1 & 2 & 0 & \\
\hline 0 & 0 & 0 & 0 & 1 & 1 & 0 & 0 & 1 & 2 & 0 & \\
\hline \multirow{2}{*}{\multicolumn{2}{|c|}{ Brachyodus depereti }} & 0 & & & & & & & & & \\
\hline & & 2 & 1 & 1 & 1 & 0 & $?$ & - & - & $?$ & \\
\hline 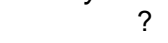 & $?$ & $?$ & 1 & 0 & 0 & 0 & 0 & 0 & 0 & 0 & \\
\hline
\end{tabular}




$\begin{array}{llllllllllll}1 & 0 & 0 & 1 & 1 & 0 & 0 & 0 & 2 & 1 & 1 & 0 \\ 0 & 1 & 0 & 0 & 0 & 0 & 0 & 0 & 0 & 2 & 0 & 1 \\ 1 & 0 & 1 & 0 & 0 & 0 & 0 & 1 & 0 & 1 & 1 & 1 \\ 2 & 2 & 0 & 0 & 0 & 1 & 0 & 1 & 1 & 2 & 0 & 0 \\ 0 & 0 & 1 & 1 & 0 & 0 & 1 & 0 & 0 & - & 0 & ? \\ ? & ? & ? & ? & ? & ? & 0 & 0 & ? & ? & ? & ? \\ 0 & ? & 1 & 1 & 1 & 1 & 0 & 0 & 1 & 0 & 0 & 0 \\ 0 & 0 & 0 & 0 & 0 & 0 & 1 & 0 & 0 & 0 & 0 & 0 \\ ? & 0 & 0 & 1 & 0 & 0 & 1 & 2 & 1 & 0 & 1 & 0 \\ 2 & 0 & 2 & 0 & 1 & 0 & 1 & 1 & 2 & 0 & 1 & ? \\ 1 & 1 & ? & 1 & ? & 0 & 0 & 1 & 1 & 1 & ? & 0 \\ ? & ? & 1 & 0 & 0 & 1 & ? & ? & 1 & ? & ? & ? \\ ? & ? & ? & ? & ? & ? & ? & ? & ? & ? & ? & ?\end{array}$

Bothriodon velaunum

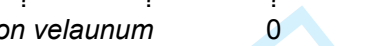

$\begin{array}{lllllllll}0 & 1 & 0 & 0 & 0 & 0 & 0 & 1 & 2 \\ 1 & 0 & 0 & 0 & 0 & 0 & 0 & 0 & 0 \\ 1 & 2 & 1 & 0 & 0 & 1 & 0 & 0 & 0 \\ 0 & 0 & 0 & 0 & 0 & 0 & 1 & 0 & 1 \\ 0 & 0 & 0 & 0 & 0 & 1 & 1 & 0 & 1 \\ 0 & 0 & 1 & 0 & 0 & 1 & 2 & 0 & 0 \\ 0 & 0 & 0 & 1 & 1 & 0 & - & 0 & 0 \\ 0 & 0 & 0 & 1 & 0 & 0 & 0 & 1 & 0 \\ 1 & 1 & 1 & 0 & 0 & 1 & 0 & 1 & 0 \\ 0 & 0 & 0 & 1 & 1 & 0 & 0 & 1 & 1 \\ 0 & 0 & 0 & 0 & 2 & 2 & 0 & 1 & 1 \\ 0 & 1 & 0 & 1 & 2 & 2 & 1 & 0 & 0 \\ 1 & 0 & 0 & 0 & ? & 1 & 1 & 2 & 1 \\ 0 & 1 & 0 & 0 & 0 & 1 & 1 & 1 & 1 \\ 0 & 1 & 1 & 0 & 0 & 1 & 0 & 0 & 1\end{array}$

Aepinacodon americanum

$\begin{array}{lllllllll}? & 1 & 0 & ? & 0 & ? & ? & ? & ? \\ 0 & 1 & 0 & 0 & 0 & 0 & 0 & 0 & 0 \\ 1 & 1 & 1 & 0 & 0 & 1 & 2 & 0 & 0 \\ 0 & 1 & 0 & 0 & 0 & 2 & 1 & 0 & 1 \\ 0 & 0 & 0 & 0 & 1 & 1 & 1 & 0 & 1 \\ 0 & 0 & 1 & 0 & 1 & 1 & 2 & 0 & 0 \\ ? & ? & ? & 1 & ? & ? & ? & ? & 0 \\ 0 & 0 & 0 & 1 & 0 & 0 & 0 & 1 & 0 \\ 1 & 1 & 0 & 0 & 0 & 1 & 1 & 1 & 0 \\ 0 & 0 & 0 & 1 & 1 & 0 & 0 & 0 & 0 \\ 0 & 0 & 0 & 0 & 2 & 2 & 0 & 1 & 1 \\ 0 & 1 & 0 & 1 & 1 & 2 & 1 & ? & ? \\ 1 & 0 & 0 & 0 & ? & 1 & 1 & 2 & 1 \\ 0 & 1 & 0 & 0 & 0 & 1 & ? & ? & ? \\ ? & ? & ? & ? & ? & ? & ? & ? & ? \\ & & & & & & & & \\ 1 & 0 & 0 & 0 & 1 & 0 & 1 & 2 & 0 \\ 0 & 0 & 0 & ? & 0 & 0 & 1 & 0 & 0 \\ ? & 1 & 0 & 0 & 1 & 1 & 1 & 1 & 0 \\ 0 & 0 & 0 & 1 & 0 & 1 & 0 & 0 & 1 \\ 0 & 0 & 0 & 0 & 1 & 1 & 0 & 1 & 0 \\ 0 & 1 & 0 & 1 & 1 & 2 & 1 & 0 & 0 \\ 0 & 0 & 1 & ? & 0 & - & ? & 0 & 0 \\ 1 & 0 & 0 & 0 & 0 & 0 & 0 & 0 & 0 \\ 1 & 1 & 0 & 0 & 1 & 0 & 0 & 0 & 0 \\ 0 & 0 & 1 & 1 & 0 & 1 & 1 & 1 & 1 \\ 0 & 0 & 1 & 2 & 2 & 0 & 1 & 1 & 2 \\ 1 & 0 & 1 & 1 & 0 & 0 & 1 & 0 & 1 \\ 0 & 0 & 1 & 0 & 1 & 0 & 1 & ? & 1 \\ 1 & 1 & 1 & 0 & 1 & ? & ? & ? & ? \\ ? & ? & ? & ? & ? & ? & ? & ? & ?\end{array}$

\section{Elomeryx borbonicus}

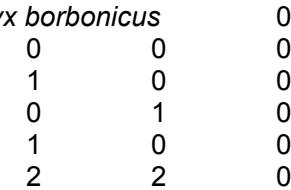




$\begin{array}{cccccccccccc}0 & 2 & 1 & 1 & 1 & 0 & 1 & 1 & 0 & - & 0 & 0 \\ 0 & 0 & 1 & 1 & 1 & 0 & 0 & 0 & 0 & 0 & 0 & 0 \\ 0 & ? & 1 & 1 & 1 & ? & 0 & 0 & 1 & 0 & 0 & 0 \\ 0 & 0 & 0 & 0 & 0 & 0 & 1 & ? & 0 & 1 & 0 & 0 \\ 1 & 0 & 0 & 1 & 0 & 0 & 1 & 2 & 2 & 0 & 1 & 1 \\ 2 & 0 & 1 & 0 & 1 & 0 & 1 & 1 & 1 & 1 & 1 & 0 \\ 2 & 1 & 1 & 1 & 0 & 0 & 2 & 0 & 1 & 0 & 2 & 1 \\ 1 & 2 & 1 & 0 & 1 & 1 & 1 & 0 & 1 & 1 & 1 & 2 \\ 0 & 0 & 0 & 0 & 1 & 1 & 0 & 0 & 1 & 1 & 1 & 1 \\ 1 & 1 & 0 & & & & & & & & \\ \text { Afromeryx zelteni } & ? & ? & ? & ? & ? & ? & ? & ? & 1 & ? & ? \\ ? & ? & 0 & 1 & 0 & 0 & 1 & 0 & 0 & 1 & 0 & 0 \\ 0 & 0 & 1 & 2 & 1 & 0 & 0 & 1 & 1 & ? & 0 & 1 \\ 1 & 0 & 0 & 0 & 1 & 1 & 0 & 2 & 1 & 0 & 1 & 1 \\ 0 & 1 & 0 & 0 & 0 & 0 & 0 & 1 & 1 & 0 & 1 & 2 \\ 2 & 0 & 0 & 0 & 1 & 0 & 0 & 0 & 0 & 0 & 0 & 0 \\ 1 & 1 & ? & 1 & 0 & 1 & 1 & 1 & 1 & 0 & 0 & ? \\ 0 & ? & 1 & 1 & 0 & 0 & 0 & 1 & 1 & 0 & 0 & 0 \\ ? & 1 & 1 & 1 & 1 & 0 & 0 & 1 & 0 & 0 & 0 & 0 \\ 0 & 0 & 0 & 0 & 0 & 1 & 1 & 0 & 0 & 0 & 0 & 0 \\ 0 & 0 & 1 & 0 & 1 & - & - & 2 & 0 & 1 & 1 & 2 \\ 0 & 2 & 0 & 1 & 0 & 1 & 1 & 1 & 0 & 1 & 0 & 2 \\ 1 & 1 & 1 & 0 & 0 & 1 & 0 & 1 & 0 & 2 & 1 & 2 \\ 0 & 1 & 0 & 0 & 1 & 1 & 1 & 1 & 0 & 0 & 1 & 1 \\ 0 & 0 & 0 & 1 & 1 & 0 & 1 & 1 & 1 & 0 & 1 & 1 \\ 1 & 1 & & & & & 0 & 1 & 1 & & & \end{array}$

Sivameryx palaeindicus

$\begin{array}{lllllllll}? & ? & ? & ? & ? & ? & ? & ? & ? \\ ? & ? & 1 & 0 & 1 & 0 & 0 & 1 & 0 \\ 1 & 2 & 1 & 0 & 0 & 2 & 1 & 0 & 0 \\ 1 & 0 & 1 & 1 & 1 & 2 & 1 & 0 & 0 \\ 0 & 0 & 0 & 0 & 0 & 1 & 1 & 0 & 1 \\ 0 & 0 & 1 & 0 & 1 & 2 & ? & 0 & 0 \\ 1 & 0 & 0 & 1 & 1 & 0 & - & 0 & ? \\ ? & ? & ? & ? & ? & 1 & 1 & 0 & 0 \\ 1 & 1 & ? & 0 & 0 & 1 & 0 & 0 & 0 \\ 0 & 0 & 0 & 1 & 1 & 0 & 0 & 0 & 0 \\ 1 & 0 & 0 & 1 & 1 & 2 & 0 & 1 & 1 \\ 0 & 1 & 0 & 1 & 1 & 1 & 0 & 1 & 0 \\ 1 & 0 & 0 & ? & ? & 1 & 0 & 2 & 0 \\ 1 & 0 & 1 & ? & ? & 1 & ? & ? & ? \\ ? & ? & ? & ? & ? & ? & ? & ? & ?\end{array}$

Sivameryx africanus

$$
\begin{array}{cccccccccccc}
\multicolumn{2}{l}{\text { Sivameryx africanus }} & 0 & ? & 0 & - & ? & ? & ? & ? & 1 & 1 \\
0 & 0 & 0 & 0 & ? & 1 & 0 & 1 & 0 & 0 & 1 & 0 \\
1 & 0 & 0 & 1 & 2 & 1 & 0 & 0 & 2 & 1 & 0 & 0 \\
0 & 1 & 0 & 1 & 0 & 1 & 0 & 0 & 2 & 1 & 0 & 1 \\
1 & 0 & 1 & 0 & ? & 0 & 0 & 1 & 1 & 1 & 0 & 1 \\
2 & 2 & 0 & 0 & 1 & 1 & 0 & 1 & 2 & 0 & 0 & 0 \\
0 & 2 & 1 & 1 & 0 & 0 & 1 & 1 & 0 & - & 0 & ? \\
? & ? & 0 & ? & ? & 0 & 0 & 0 & 1 & 1 & ? & 0 \\
0 & ? & 1 & 1 & 1 & ? & ? & ? & 1 & ? & 1 & ? \\
? & 0 & 0 & ? & ? & 0 & 1 & 1 & 0 & 0 & 0 & 0 \\
1 & 0 & 0 & 1 & 0 & 0 & 1 & 2 & 2 & 0 & 1 & 1 \\
2 & 0 & 1 & 0 & 1 & 0 & 1 & 1 & ? & 0 & 1 & ? \\
2 & 1 & 1 & 1 & 0 & 0 & 2 & 1 & 1 & 0 & 2 & 0 \\
2 & 0 & 1 & 1 & 0 & 1 & 1 & ? & 1 & 2 & 1 & 0 \\
- & - & - & - & - & - & - & - & - & 1 & 1 & 2
\end{array}
$$

Hemimeryx blanford

\begin{tabular}{ccc}
\multicolumn{2}{c}{ ryx blanfordi } & $?$ \\
$?$ & $?$ & 0 \\
1 & 0 & 0 \\
0 & 1 & 0 \\
1 & 0 & 0 \\
2 & 2 & $?$ \\
0 & 2 & 1 \\
$?$ & $?$ & $?$ \\
$?$ & $?$ & 1 \\
0 & 0 & 0
\end{tabular}

$\begin{array}{ll}? & \\ ? & \\ 1 & \\ 1 & \\ 0 & \\ 0 & \\ 0 & \\ ? & \\ 1 & \\ 0 & \end{array}$

$\begin{array}{lll}? & ? & ? \\ ? & 1 & 0 \\ 2 & 1 & 0 \\ 0 & 1 & 0 \\ 0 & 0 & 0 \\ 0 & 1 & 0 \\ 0 & 0 & 1 \\ ? & ? & ? \\ 0 & - & 0 \\ 0 & 0 & 1\end{array}$

$?$
1
0
0
0
1
1
$?$
0
1

$$
\begin{aligned}
& ? \\
& 0 \\
& 2 \\
& 2 \\
& ? \\
& 2 \\
& 0 \\
& ? \\
& 1 \\
& ?
\end{aligned}
$$

$\begin{array}{lll}? & 1 & 2 \\ 0 & 1 & 0 \\ 1 & 0 & 0 \\ 1 & 0 & 0 \\ 1 & 0 & 1 \\ 0 & 0 & 0 \\ - & 0 & ? \\ ? & ? & ? \\ 0 & 0 & 0 \\ 0 & 0 & 0\end{array}$


Lihoreau et al. Supporting information

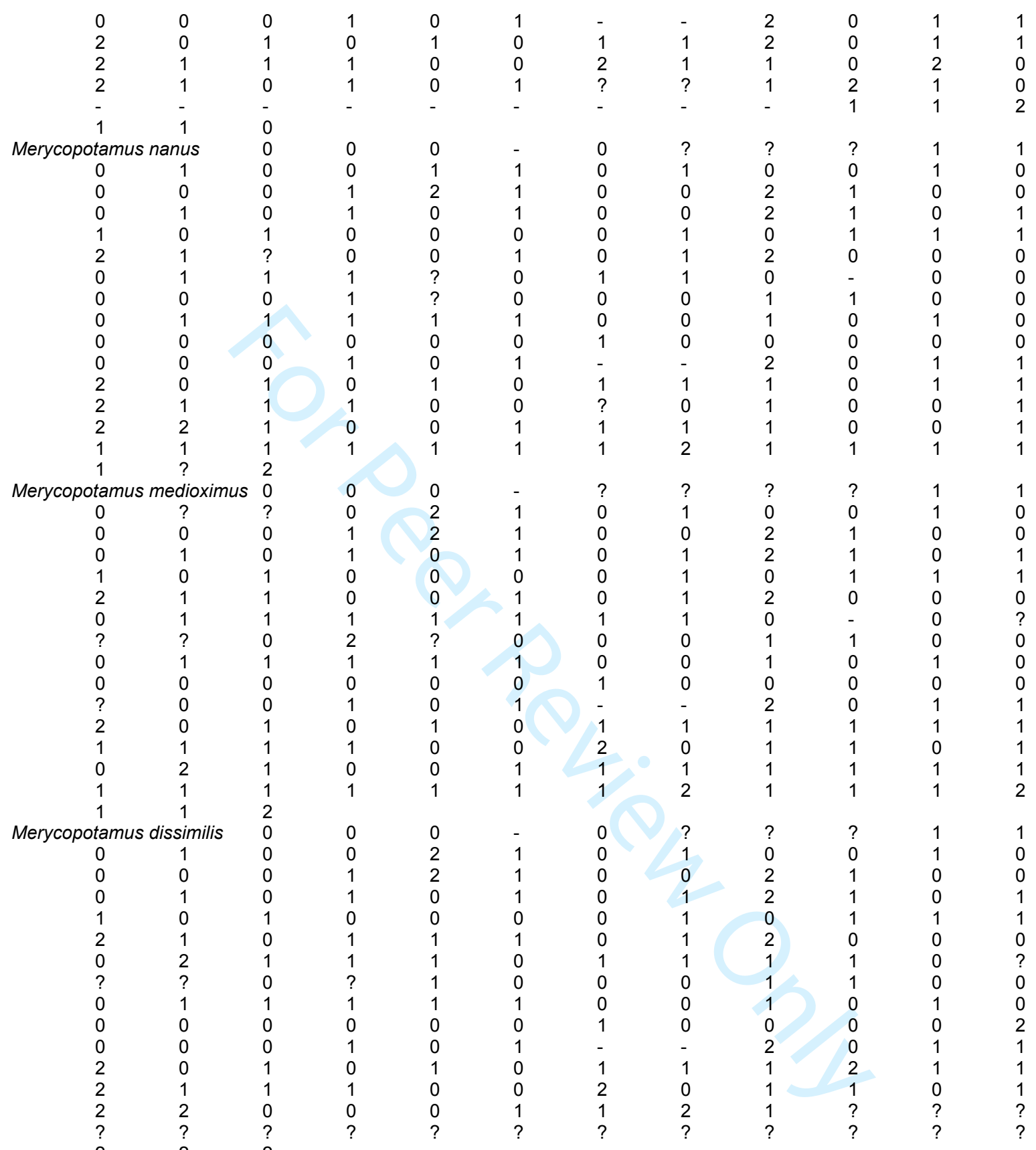

Libycosaurus algeriensis

$\begin{array}{lllllllll}? & ? & ? & ? & ? & ? & ? & ? & ? \\ ? & ? & ? & 0 & 2 & 0 & 0 & 1 & 0 \\ 1 & 2 & 1 & 0 & 0 & 2 & 1 & 0 & 0 \\ 1 & 0 & 1 & 1 & 2 & 2 & 1 & 0 & 1 \\ 0 & 0 & 0 & 0 & 1 & 0 & 1 & 1 & 1 \\ 1 & ? & 1 & 0 & 1 & 2 & 0 & 0 & 0 \\ 1 & 1 & 0 & 1 & 1 & 1 & 0 & 0 & ? \\ 2 & ? & ? & ? & ? & ? & ? & ? & ? \\ ? & ? & ? & ? & ? & ? & ? & ? & ? \\ ? & ? & 0 & 1 & 0 & 0 & 0 & 0 & 2 \\ 1 & 0 & 1 & - & - & 2 & 0 & 1 & 1 \\ 0 & 1 & 0 & 1 & 1 & 2 & 1 & 1 & 1 \\ 1 & 0 & 0 & ? & ? & ? & ? & ? & ? \\ ? & ? & 1 & ? & ? & 1 & 1 & 1 & 1\end{array}$

URL: http://mc.manuscriptcentral.com/ghbi 


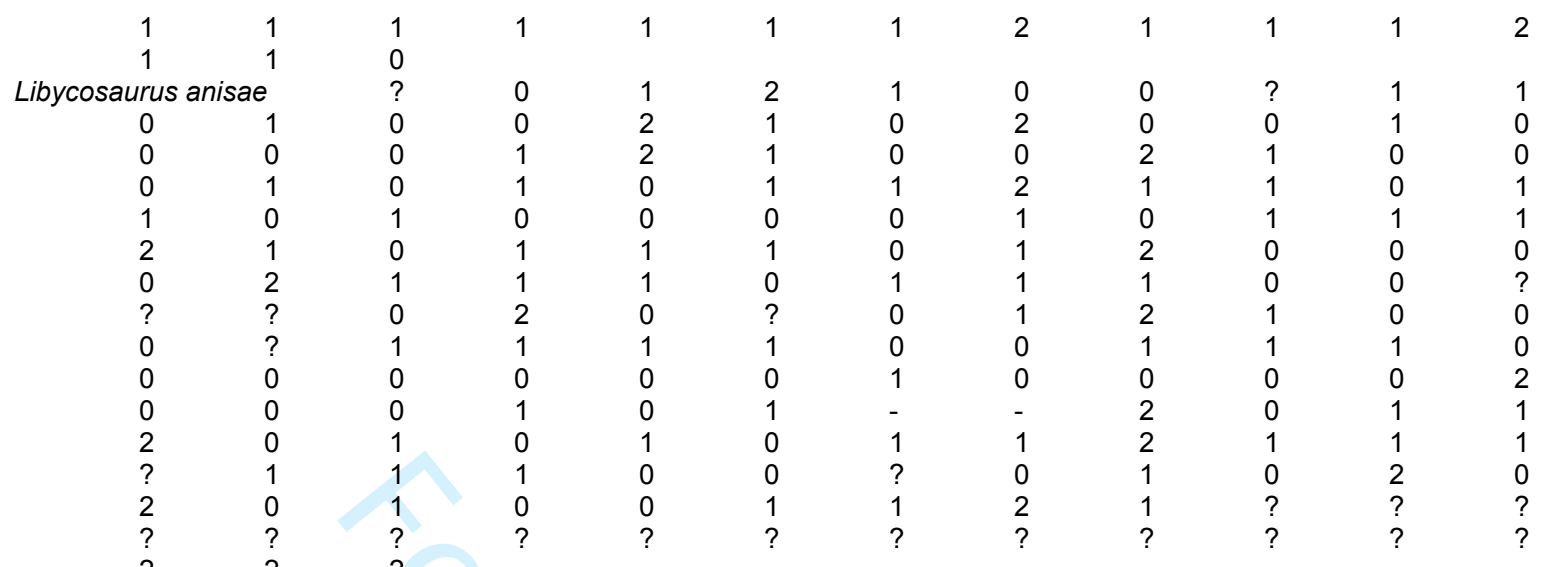

Libycosaurus bahri 2

$\begin{array}{lllllllll}1 & 2 & 1 & 0 & 0 & 1 & 1 & 1 & 0 \\ 2 & 1 & 0 & 2 & 0 & 0 & 1 & 0 & 0 \\ 2 & 1 & 0 & 0 & 2 & 1 & 0 & 0 & 0 \\ 0 & 1 & 1 & 2 & 1 & 1 & 0 & 1 & 1 \\ 0 & 0 & 0 & 1 & 0 & 1 & 1 & 1 & 2 \\ 1 & 1 & 0 & 1 & 2 & 0 & 0 & 0 & 0 \\ 1 & 0 & 1 & 1 & 1 & 1 & 0 & 0 & 0 \\ ? & 0 & 0 & 1 & 2 & 1 & 0 & 0 & 0 \\ 1 & 1 & 0 & 0 & 1 & 0 & 1 & 0 & 0 \\ 0 & 0 & 1 & 0 & 0 & 0 & 0 & 2 & 0 \\ 0 & 1 & - & - & 2 & 0 & 1 & 1 & 2 \\ 1 & 0 & 1 & 1 & 2 & 1 & 1 & 1 & 1 \\ 0 & 0 & 2 & 0 & 1 & 1 & 2 & 0 & 2 \\ ? & 1 & 1 & 2 & 1 & 2 & 1 & 0 & - \\ - & - & - & - & - & 1 & 1 & 2 & 1\end{array}$

\section{Epirigenys lokonensis}

$$
\text { ? }
$$

$$
?
$$$$
\begin{aligned}
& ? \\
& ? \\
& 0
\end{aligned}
$$$$
\begin{array}{ll}
? & ? \\
0 & 0 \\
1 & 1 \\
1 & 0 \\
2 & 1 \\
1 & 2 \\
? & ? \\
? & ? \\
1 & 0 \\
0 & 1 \\
2 & 0 \\
1 & 1 \\
? & ? \\
0 & 0 \\
1 & 1
\end{array}
$$
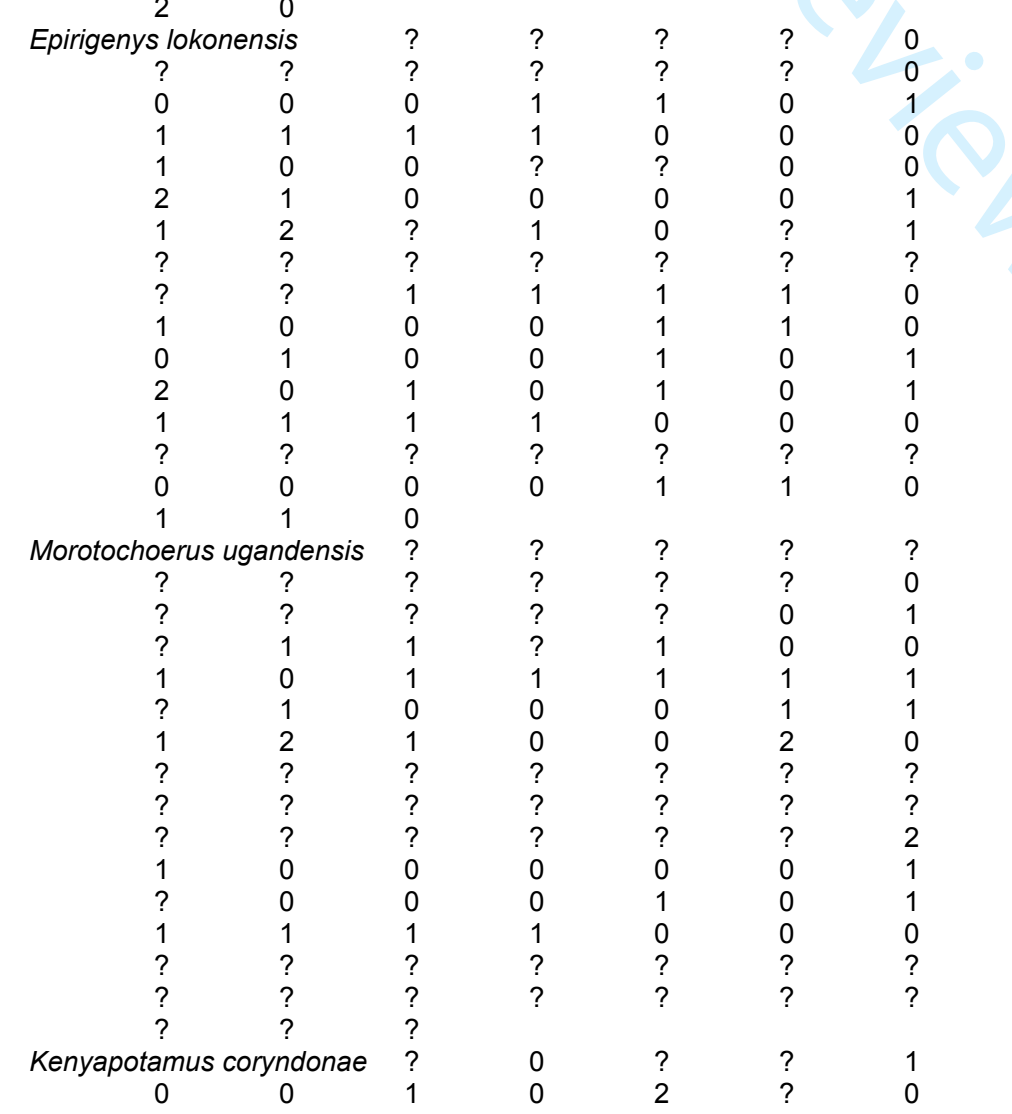
Lihoreau et al. Supporting information

$$
\begin{array}{cccccccccccc}
\multicolumn{2}{c}{\text { Chororatherium roobii }} & ? & ? & ? & ? & ? & ? & ? & ? & 1 & 2 \\
0 & ? & ? & 0 & 2 & ? & 0 & 0 & ? & ? & ? & ? \\
? & ? & ? & ? & ? & ? & ? & - & ? & ? & ? & ? \\
? & ? & ? & ? & ? & ? & 0 & ? & ? & ? & ? & 1 \\
1 & 0 & 1 & 0 & 1 & ? & 1 & 1 & 1 & 0 & 0 & 1 \\
2 & 0 & 1 & ? & 0 & 1 & 1 & 0 & ? & ? & 0 & 1 \\
? & ? & ? & 1 & 1 & ? & ? & 0 & 1 & 0 & 0 & ? \\
? & ? & ? & ? & ? & ? & ? & ? & 2 & 0 & ? & 1 \\
0 & 1 & ? & ? & 1 & 1 & 0 & 0 & 1 & 1 & ? & 1 \\
? & 0 & 0 & 1 & 1 & ? & 2 & 0 & 0 & 2 & 0 & 0 \\
1 & 0 & 0 & ? & 0 & 0 & 1 & 1 & 0 & 1 & 1 & 0 \\
? & 0 & 0 & 0 & 1 & 0 & 1 & 0 & 2 & 0 & 0 & 0 \\
2 & 1 & ? & ? & ? & 0 & ? & ? & ? & ? & ? & ? \\
? & ? & ? & 0 & ? & ? & ? & ? & 1 & ? & ? & ? \\
? & ? & ? & ? & ? & ? & ? & ? & ? & ? & ? & ?
\end{array}
$$
Chorora hippopotamine ?

$\begin{array}{lllllllll}0 & ? & ? & 1 & ? & ? & ? & 1 & 2 \\ 0 & 2 & ? & 0 & 0 & ? & ? & ? & ? \\ ? & ? & ? & ? & - & 1 & ? & 1 & 0 \\ 1 & 1 & 0 & 0 & ? & 0 & ? & ? & 1 \\ 0 & 1 & 3 & 1 & 1 & 1 & 0 & 0 & 1 \\ 1 & 0 & 1 & 1 & 0 & 3 & 0 & 0 & 1 \\ ? & ? & ? & 0 & ? & ? & ? & 0 & ? \\ 3 & ? & ? & ? & ? & 2 & 0 & ? & 2 \\ 0 & 1 & 1 & 0 & 0 & 1 & 1 & 1 & 1 \\ 1 & 1 & 0 & 2 & 0 & 0 & 2 & 0 & 0 \\ ? & 0 & ? & ? & ? & 0 & 0 & 1 & 0 \\ 0 & 1 & 0 & 1 & 0 & ? & 0 & 0 & 0 \\ ? & ? & 0 & ? & ? & ? & ? & ? & ? \\ 0 & ? & ? & ? & ? & 1 & ? & ? & ? \\ ? & ? & ? & ? & ? & ? & ? & ? & ?\end{array}$

Archaeopotamus harvardi

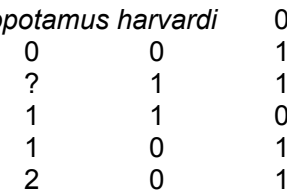




$\begin{array}{cccccccccccc}1 & 2 & 1 & 1 & 1 & 2 & 0 & 0 & 0 & - & 0 & 0 \\ 0 & 0 & 0 & 3 & 1 & 0 & 1 & 0 & ? & 0 & 0 & 2 \\ 0 & 1 & 2 & 0 & 1 & 1 & 0 & 0 & 1 & 1 & 0 & 1 \\ 1 & 0 & 0 & 1 & 1 & 0 & 2 & 0 & 0 & 2 & 0 & 0 \\ 1 & 0 & 0 & ? & 0 & ? & - & - & 0 & ? & 1 & 0 \\ ? & 0 & 0 & 0 & 1 & 0 & 1 & 0 & 2 & 0 & 0 & 0 \\ 2 & 1 & 1 & 1 & 1 & 0 & 0 & 1 & 1 & 1 & 0 & 2 \\ 0 & 0 & 0 & 0 & 1 & ? & 1 & 2 & 1 & ? & ? & ? \\ ? & ? & ? & ? & ? & ? & ? & ? & ? & ? & ? & ? \\ ? & ? & ? & & & & & ? & & \\ \text { rexaprotodon garyam } & 0 & 0 & 1 & 2 & 1 & 2 & 0 & 1 & 1 & ? \\ 0 & 0 & 1 & 0 & 2 & 0 & 0 & 0 & 0 & 0 & 2 & 1 \\ ? & 1 & 1 & 1 & 0 & 1 & 1 & - & 1 & 2 & 1 & 0 \\ 1 & 1 & 0 & 1 & 1 & 0 & 0 & ? & 0 & ? & ? & 1 \\ 1 & 0 & 1 & 1 & 1 & 3 & 1 & 1 & 1 & 0 & 0 & 1 \\ ? & 0 & 1 & ? & 0 & 1 & 1 & 0 & 3 & 0 & ? & 1 \\ 1 & 2 & 1 & 1 & 1 & 2 & 0 & 0 & 0 & - & 0 & 0 \\ 0 & 0 & 0 & 3 & 1 & 0 & ? & 0 & ? & 0 & 0 & 2 \\ 0 & 1 & 2 & 0 & 1 & 1 & 0 & 0 & 1 & 1 & 0 & 1 \\ 1 & 0 & 0 & 1 & 1 & 0 & 2 & 0 & 0 & 2 & 0 & 0 \\ 1 & 0 & 0 & ? & 0 & ? & - & - & 0 & ? & 1 & 0 \\ ? & 0 & 0 & 0 & 1 & 0 & 1 & 0 & 2 & 0 & 0 & 0 \\ 2 & 1 & 1 & 1 & 1 & 0 & ? & 1 & 1 & 1 & 0 & 2 \\ 0 & 0 & 0 & 0 & 1 & ? & 1 & ? & 1 & 1 & 1 & 1 \\ 1 & 1 & 1 & 1 & 1 & 1 & 1 & 2 & 1 & 2 & 1 & 2\end{array}$

Palaeochoerus quercyi

$\begin{array}{llllllll}1 & ? & 0 & 1 & 0 & 0 & 1 & 3 \\ 2 & 0 & 0 & 0 & 0 & 0 & 0 & 0 \\ 0 & 0 & 0 & - & 0 & - & 0 & 0 \\ 0 & 0 & 1 & 1 & 0 & 0 & 1 & 1 \\ 1 & 0 & 0 & 0 & 0 & 1 & 1 & 0 \\ 0 & 1 & 1 & 0 & 1 & 0 & 0 & 0 \\ 0 & 0 & 0 & 0 & 0 & 0 & 0 & 0 \\ 1 & ? & 0 & 0 & 0 & 0 & 0 & 1 \\ 0 & - & 0 & 0 & 0 & 1 & 1 & 0 \\ 0 & 2 & 2 & 0 & 1 & 0 & 0 & 1 \\ 0 & 0 & 1 & 0 & 0 & 0 & 0 & 1 \\ 1 & 0 & 0 & - & 2 & - & 0 & 1 \\ 1 & 0 & 1 & 0 & 1 & 1 & ? & 1 \\ 0 & 1 & ? & 0 & 0 & 0 & 0 & 2 \\ 0 & 0 & 0 & ? & 0 & 0 & 0 & 0\end{array}$

\section{Kenyasus rusingensis}

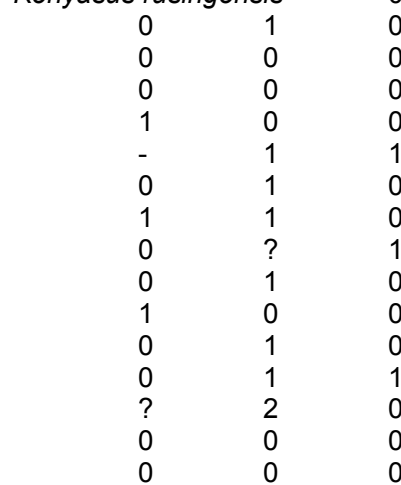

Perchoerus probus 0

$\begin{array}{ccc}\text { rus probus } & 0 & 0 \\ 1 & 1 & 0 \\ ? & 0 & ? \\ 0 & 0 & 1 \\ 0 & 0 & 1 \\ ? & 1 & ? \\ 1 & 0 & 0 \\ ? & 0 & 2 \\ ? & 0 & 0 \\ 1 & 0 & 0\end{array}$

$\begin{array}{lll}1 & ? & 0 \\ 2 & 0 & 0 \\ ? & 0 & 0 \\ 0 & 0 & 0 \\ 1 & 0 & 0 \\ 0 & 1 & 0 \\ ? & 0 & 0 \\ ? & ? & 1 \\ 0 & - & 0 \\ 0 & 2 & 2\end{array}$

0
0
0
0
0
0
0
1
0
2
1
0
1
0
0

$\begin{array}{lllll}1 & 0 & 0 & 1 & 3 \\ 0 & 0 & 0 & 0 & 0 \\ - & 0 & - & 0 & 0 \\ ? & ? & ? & ? & 1 \\ 0 & 1 & 0 & 0 & 0 \\ 0 & 1 & 0 & 1 & 0 \\ 0 & 0 & 0 & 0 & 0 \\ 0 & 0 & 0 & ? & 0 \\ 0 & 1 & 0 & 1 & 0 \\ 0 & 1 & 0 & 0 & 1 \\ 0 & 0 & 1 & 0 & 1 \\ - & 2 & - & 0 & 1 \\ 0 & 0 & 1 & ? & 1 \\ ? & 0 & 1 & 1 & 2 \\ 0 & 1 & 0 & 0 & 1\end{array}$




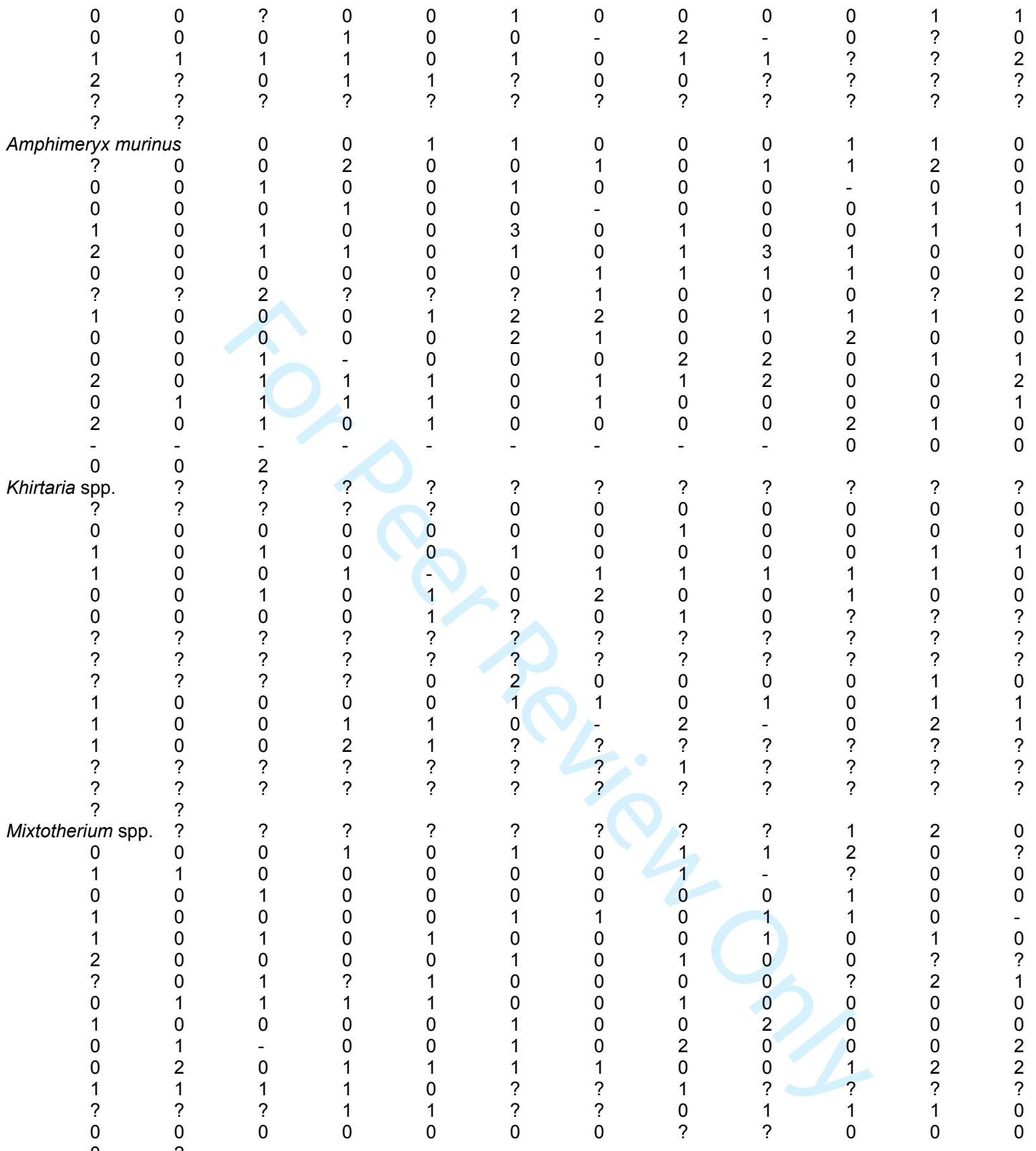




\begin{tabular}{|c|c|c|c|c|c|c|c|c|c|c|c|}
\hline 1 & 0 & 0 & 0 & 1 & 0 & 0 & ? & 1 & 1 & 0 & 0 \\
\hline Dacrytherium ovinu & $m$ & 0 & ? & ? & ? & 0 & 0 & ? & ? & 1 & 2 \\
\hline 1 & 0 & 0 & 2 & 0 & 0 & 0 & 0 & 1 & 0 & 0 & 0 \\
\hline 0 & 0 & 1 & 1 & 1 & 0 & 0 & 0 & 2 & 2 & 1 & 0 \\
\hline 0 & 1 & 0 & 1 & 0 & 0 & 0 & 1 & 0 & 0 & 1 & 0 \\
\hline 1 & 1 & 1 & 0 & 0 & 0 & 0 & 0 & 0 & 0 & 1 & 0 \\
\hline- & 1 & 1 & 0 & 0 & 1 & 0 & 1 & 2 & 0 & 0 & 0 \\
\hline 1 & 0 & 0 & 0 & 0 & 0 & 1 & 0 & 0 & - & 0 & 0 \\
\hline ? & ? & 2 & 0 & ? & 1 & 0 & 0 & 0 & 0 & 0 & 2 \\
\hline 0 & 1 & 1 & 1 & 0 & - & 2 & 0 & 1 & 0 & 1 & 1 \\
\hline 0 & 0 & 0 & 0 & 1 & 0 & 1 & 0 & 0 & 0 & 0 & 0 \\
\hline 0 & 0 & 1 & - & 0 & 0 & 1 & 0 & 2 & 0 & 1 & 1 \\
\hline 2 & 0 & 2 & 1 & 1 & 0 & 1 & 1 & 0 & 0 & 1 & 2 \\
\hline 0 & 1 & 1 & 1 & 0 & 0 & 1 & 0 & 0 & 0 & ? & 1 \\
\hline 1 & $?$ & 0 & 0 & 0 & 1 & $?$ & ? & 0 & ? & ? & ? \\
\hline ? & $?$ & ? & ? & ? & ? & ? & ? & ? & ? & ? & ? \\
\hline$?$ & $?$ & ? & & & & & & & & & \\
\hline Diplobune minor & 0 & 0 & 1 & 0 & 0 & 0 & 0 & 1 & 1 & 2 & 1 \\
\hline 0 & 0 & 1 & 0 & 0 & 0 & 0 & 1 & 1 & 0 & 0 & 0 \\
\hline 1 & 1 & 1 & 1 & 0 & 0 & 0 & 2 & 0 & 1 & 0 & 0 \\
\hline 0 & 0 & 1 & 0 & 0 & 0 & 0 & 0 & 0 & 1 & 1 & 0 \\
\hline 0 & 1 & 0 & 0 & 0 & 0 & 1 & 0 & 1 & 1 & 0 & \\
\hline 1 & 1 & 0 & 0 & 1 & 1 & 1 & 2 & 2 & 0 & 0 & 0 \\
\hline 0 & 0 & 0 & 0 & 0 & 1 & 0 & 0 & & 0 & 0 & 2 \\
\hline 1 & 2 & 0 & 0 & 1 & 0 & 0 & 0 & 0 & 1 & 2 & 0 \\
\hline 1 & 1 & 1 & 1 & 2 & 2 & 0 & 1 & 0 & 1 & 0 & \\
\hline 0 & 0 & 0 & 0 & 2 & 1 & 0 & 0 & 0 & 0 & 0 & 0 \\
\hline 0 & 1 & - & 0 & 0 & 1 & 0 & 2 & 0 & 0 & 1 & \\
\hline 0 & 1 & 1 & 1 & 0 & 1 & 1 & 0 & 0 & 1 & 2 & \\
\hline 1 & 1 & 1 & 0 & 0 & 1 & 0 & 0 & 0 & 0 & 1 & 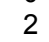 \\
\hline 0 & 0 & 0 & 0 & 1 & 0 & ? & 0 & 1 & 1 & 1 & \\
\hline 0 & 0 & 0 & ? & 0 & 0 & 0 & 1 & 0 & 0 & 0 & 0 \\
\hline
\end{tabular}

Paroxacron valdense
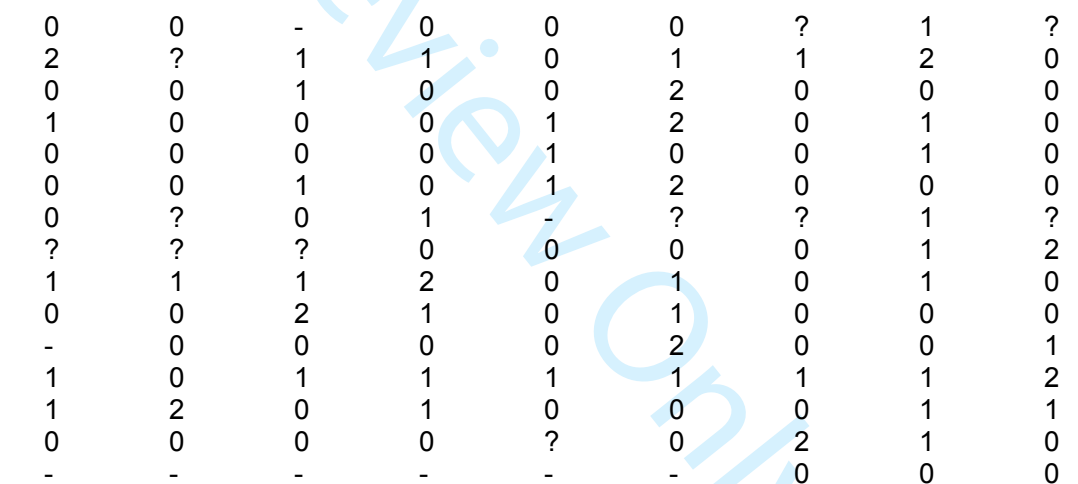

Entelodon spp.

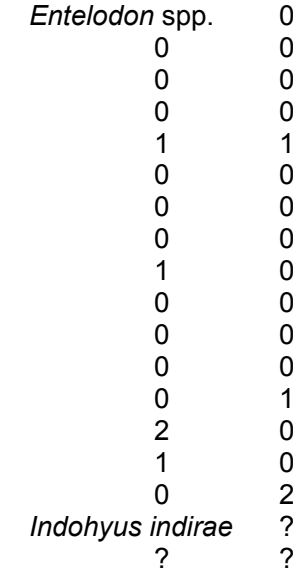

$$
\begin{aligned}
& 1 \\
& 1 \\
& 0 \\
& 0 \\
& 0 \\
& 0 \\
& 0 \\
& ? \\
& 1 \\
& 0 \\
& 0 \\
& 0 \\
& 2 \\
& 0 \\
& 0 \\
& ? \\
& ?
\end{aligned}
$$

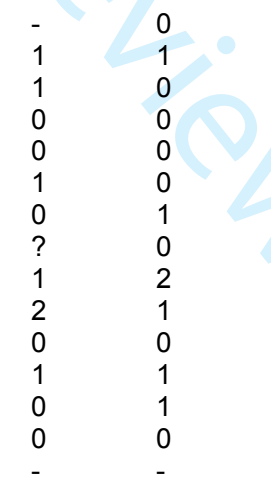

$?$
0
0
0
0
0
$?$
2
0
0
1
2
1
0
0


Lihoreau et al. Supporting information

$\begin{array}{cccccccccccc}? & ? & ? & ? & 0 & 0 & 0 & 1 & 0 & 0 & 0 & 0 \\ 0 & 0 & 1 & 0 & 0 & 0 & 0 & 0 & 0 & 0 & 1 & 1 \\ 1 & 0 & 0 & 0 & 0 & 0 & 1 & 0 & 1 & 1 & 1 & 0 \\ 0 & 0 & 0 & 0 & 1 & 0 & 2 & 0 & 0 & 1 & 0 & 0 \\ 0 & 0 & 0 & 0 & 1 & 2 & 0 & 1 & 0 & 0 & ? & ? \\ ? & ? & ? & ? & ? & ? & ? & 0 & 0 & ? & 0 & 0 \\ 1 & 0 & 0 & 0 & - & - & 0 & 0 & 0 & 0 & 0 & 0 \\ 0 & 1 & 1 & 0 & 0 & 2 & 0 & 0 & 2 & 0 & 1 & 0 \\ 0 & 1 & - & 0 & 0 & 1 & 1 & 0 & 1 & 0 & 1 & 1 \\ 1 & 0 & 0 & 1 & 1 & 0 & - & 2 & - & 0 & 2 & 1 \\ 1 & ? & 1 & 0 & 0 & ? & ? & ? & ? & ? & ? & ? \\ ? & ? & ? & ? & ? & 1 & 0 & ? & ? & ? & ? & ? \\ ? & ? & ? & ? & ? & ? & ? & ? & ? & ? & ? & ? \\ ? & ? & & & & & & & & & & \\ \text { Merycoidodon sp. } & ? & ? & ? & ? & ? & ? & ? & ? & 0 & 1 & 0 \\ 0 & 0 & 0 & 1 & 0 & 0 & 0 & 0 & 0 & 2 & 0 & 1 \\ 1 & 1 & 1 & 1 & 0 & 0 & 0 & 1 & 0 & 0 & 1 & 0 \\ 1 & 0 & 1 & 0 & 0 & 1 & 1 & 0 & 0 & 1 & 0 & 1 \\ 0 & 1 & 0 & 0 & - & 0 & 0 & 0 & 0 & 1 & 1 & 2 \\ 2 & 1 & 0 & 0 & 1 & 0 & 1 & 3 & 2 & 0 & 0 & 1 \\ 2 & 0 & 0 & ? & 0 & 1 & ? & ? & ? & ? & 0 & 0 \\ 0 & 0 & 1 & ? & 0 & 0 & 0 & 0 & 1 & 0 & 0 & 0 \\ 0 & 0 & 1 & 1 & 2 & 2 & 0 & 1 & 0 & 0 & 0 & 0 \\ 0 & 0 & 0 & 0 & 2 & 0 & 0 & 0 & 2 & 0 & 0 & 0 \\ 0 & 1 & - & 0 & 1 & - & - & 2 & 0 & 0 & 1 & 2 \\ 0 & 2 & 1 & 1 & 0 & 1 & 1 & 0 & 0 & 1 & ? & 2 \\ 1 & 1 & 1 & 0 & 0 & 1 & ? & 0 & ? & ? & 1 & 2 \\ 0 & 0 & 0 & 0 & 1 & 1 & 0 & 0 & ? & ? & ? & ? \\ ? & ? & ? & ? & ? & ? & ? & ? & ? & ? & ? & ? \\ ? & ? & ? & & ? & & ? & ?\end{array}$

Amphiraghatherium spp.

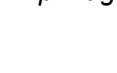

30

31

32

33

34

35

36

37 


$\begin{array}{cccccccccccc}0 & 0 & 0 & 0 & 0 & 0 & 1 & ? & ? & ? & 0 & 0 \\ 0 & 0 & 1 & 0 & ? & 0 & 1 & 2 & 0 & 0 & 1 & 2 \\ ? & ? & 0 & 1 & 1 & 0 & 2 & 0 & 1 & 0 & 0 & 0 \\ 0 & 0 & 0 & 0 & 0 & 0 & 1 & 0 & 1 & 2 & 0 & 0 \\ 0 & 0 & 1 & - & 0 & 1 & - & - & 1 & 0 & 1 & 0 \\ 2 & 0 & 2 & 1 & 1 & 1 & 1 & 1 & 0 & 0 & 1 & ? \\ 1 & 1 & 1 & 1 & 0 & 0 & ? & ? & 1 & ? & ? & 1 \\ ? & ? & 0 & 0 & 1 & 1 & ? & ? & 0 & ? & ? & ? \\ ? & ? & ? & ? & ? & ? & ? & ? & ? & ? & ? & ? \\ ? & ? & ? & & & & & & & ? \\ \text { Lophiomeryx chalaniati } & 0 & 0 & 1 & 2 & 0 & 0 & 1 & ? & 1 & ? \\ ? & ? & ? & 2 & 0 & 0 & 1 & 0 & 1 & 1 & 2 & 0 \\ 0 & 0 & 1 & 0 & 0 & 0 & 0 & 0 & 1 & - & 0 & 0 \\ 0 & 0 & 0 & 1 & 0 & 0 & 0 & 0 & 2 & 0 & 1 & 1 \\ 1 & 0 & 1 & 0 & 0 & 3 & 0 & 1 & 0 & 0 & 1 & 1 \\ 2 & 0 & 1 & 0 & 0 & 1 & 0 & 1 & 3 & 0 & 0 & 0 \\ 0 & 2 & 0 & 0 & 0 & 0 & 1 & 1 & 1 & 1 & 0 & ? \\ - & - & 2 & ? & 0 & 0 & 1 & 2 & 0 & 0 & 1 & 1 \\ 0 & 0 & 0 & 1 & 1 & 2 & 2 & 0 & 1 & 1 & 1 & 0 \\ 0 & 0 & 0 & 0 & 0 & 0 & 1 & 0 & 0 & 2 & 0 & 0 \\ 0 & 0 & 1 & - & 0 & 1 & - & - & 2 & 0 & 1 & 1 \\ 2 & 0 & 1 & 1 & 1 & 0 & 1 & 1 & 0 & 0 & 1 & ? \\ 1 & 1 & 1 & 1 & 0 & 0 & 1 & 0 & 1 & 0 & ? & 0 \\ 2 & 2 & 0 & 0 & 1 & 1 & 1 & ? & 0 & ? & ? & ? \\ ? & ? & ? & ? & ? & ? & ? & ? & ? & ? & ? & ? \\ ? & ? & ? & & & & & ? & & \\ ?\end{array}$


Lihoreau et al. Supporting information

\section{Supplementary References}

1 Boisserie J-R, Lihoreau F, Orliac M, Fisher RE, Weston EM, et al. (2010) Morphology and phylogenetic relationships of the earliest known hippopotamids (Cetartiodactyla, Hippopotamidae, Kenyapotaminae). Zool J Linn Soc 158: 325-366.

2 Alloing-Séguier $\mathrm{L}$ et al. (2014) Enamel microstructure evolution in anthracotheres (Mammalia, Cetartiodactyla) and new insights on hippopotamoid phylogeny. Zool J Linn Soc 171: 668-695.

3 Ducrocq S (1997) The anthracotheriid genus Bothriogenys (Mammalia, artiodactyla) in Africa and Asia during the Paleogene: phylogenetical and paleobiogeographical relationships. Stuttgarter Beiträge zur Naturkunde 250: 1-44.

4 Damuth J (1990) in Body size in Mammalian Paleobiology: estimation and biological implications, eds Damuth J, McFadden (Cambridge University press, Cambridge), pp. 229-253.

5 Hershkovitz P (1971) Basic crown patterns and cusp homologies of mammalian teeth. In: Dahlberg AA, editor editors. Dental morphology and evolution. Chicago: The University of Chicago Press. pp. 95-150.

$6 \quad$ Butler PM (1978) Molar cusp nomenclature and homology. In: Butler PM,Joysey KA, editors. Development, Function and Evolution of Teeth. London: Academic Press. pp. 439-453.

7 Gentry AW,Hooker JJ (1988) The phylogeny of the Artiodactyla. In: Benton MJ, editor editors. The phylogeny and classification of the Tetrapods, Volume 2 : Mammals. Oxford: Clarendon Press. pp. 235272.

8 Made J van der (1996) Listriodontinae (Suidae, Mammalia), their evolution, systematics and distribution in time. Contributions to Tertiary and Quaternary Geology 33: 3-254.

9 Tassy P (1996) Dental homologies and nomenclature in the Proboscidea. In: Shoshani J,Tassy P, editors. The Proboscidea Evolution and Palaeoecology of Elephants and their Relatives. Oxford: Oxford University Press. pp. 21-25.

10. Van Valen L (1966) Deltatheridia, a new order of mammals. Bulletin of the American Museum of Natural History 132: 1-128.

11 Hünermann KA (1968) Die Suidae (Mammalia, Artiodactyla) aus den Dinotheriensanden (Unterpliozän = Pont) Rheinhessens (Südwestdeutschland). Mémoires suisses de Paléontologie 86: 1-96. 12 Orliac M (2006) Eurolistriodon tenarezensis, sp. nov., from Montréal-du-Gers (France): implications for the systematics of the European Listriodontinae (Suidae, Mammalia). $J$ Vertebr Paleontol 26: 967-980.

13 Orliac M (2007) Le rôle des Listriodontinae dans la différenciation des Suidae (Mammalia) ; paléoanatomie, systématique, phylogénie. Unpublished dissertation, Paris: Université Pierre et Marie Curie - Paris VI. pp. 702.

14 Smith JB, Dodson P (2003) A proposal for a standard terminology of anatomical notation and orientation in fossil vertebrate dentitions. J Vertebr Paleontol 23: 1-12. 
Lihoreau et al. Supporting information

15 Pickford M (1983) On the origins of Hippopotamidae together with descriptions of two species, a new genus and a new subfamily from the Miocene of Kenya. Geobios 16:193-217.

16 Nakaya H, Pickford M, Nakano Y, Ishida H (1984) The late Miocene large mammal fauna from the Namurungule Formation, Samburu Hills, northern Kenya. Afr Study Monogr suppl 2:87-131.

17 Nakaya H, Pickford M, Yasui K, Nakano Y (1987) Additional large mammalian fauna from the Namurungule Formation, Samburu Hills, northern Kenya. Afr Study Monogr suppl 5:47-98.

18 Tsujikawa $\mathrm{H}$ (2005) The updated late Miocene large mammal fauna from Samburu Hills, northern Kenya. Afr Study Monogr suppl 32:1-50.

19 Coryndon SC (1977) The taxonomy and nomenclature of the Hippo-potamidae (Mammalia, Artiodactyla) and a description of two new fossil species. Proc Koninkl Nederland Acad Wetenschap 80:61-88.

20 Weston EM (2003) in Lothagam. The dawn of humanity in eastern Africa, eds Harris JM, Leakey MG (Columbia University Press, New York), pp 380-410.

21 Boisserie J-R, Likius A, Vignaud P, Brunet M (2005) A new late Miocene hippopotamid from Toros-Menalla, Chad. J Vertebr Paleontol 25:665-673.

22 Pickford M (1998) A new genus of Tayassuidae (Mammalia) from the Middle Miocene of Uganda and Kenya. Ann Paléontol 84:275-285.

23 Pickford M, Sawada Y, Tayama R, Matsuda Y, Itaya T, Hyodo H, Senut B (2006) Refinement of the age of the Middle Miocene Fort Ternan Beds, Western Kenya, and its implications for Old World biochronology. C R Geosciences 338:545-555.

24 Orliac M, Boisserie J-R, Lihoreau F, MacLatchy L (2010) Early Miocene hippopotamids (Cetartiodactyla) constrain the phylogenetic and spatiotemporal settings of hippopotamid origin. Proc Natl Acad Sci USA 107: 11871-11876.

25 Suteethorn V, Buffetaut E, Helmcke-Ingavat R, Jaeger J-J, Jongkanjanasoontorn Y (1988) Oldest known Tertiary mammals from south east Asia: middle Eocene primate and anthracotheres from Thailand. N Jb Geol Pal Mh 9:563-570.

26 Ducrocq $S$ (1994) Les anthracothères paléogènes de Thaïlande : paléogéographie et phylogénie. C R Acad Sci 318:549-554.

27 Ducrocq S (1999) The late Eocene Anthracotheriidae (Mammalia, Artiodactyla) from Thailand. Palaeontogr Abt A 252:93-140.

28 Scott WB (1940) in The Mammalian fauna of the White River Oligocene, eds Scott WB, Jepsen GL (Transaction of the American Philosophical Society, Philadelphia), pp. 363-746.

29 Macdonald JR (1956) The North American anthracotheres. J Paleontol 30: 615-645.

30 Cuvier G (1822) Recherches sur les ossemens fossiles (Edmond d'Ocagne éditeur, Paris).

31 Leymerie A (1851) Mémoire sur un nouveau type pyrénéen parallèle à la craie proprement dite. Mém Acad Sci Toulouse 4:388-394. 
Lihoreau et al. Supporting information

32 Lihoreau F, Ducrocq S (2007) in The Evolution of Artiodactyls, eds Prothero DR, Foss SE (The Johns Hopkins University Press, Baltimore), pp 89-105.

33 Tsubamoto $\mathrm{T}$ et al. (2011) A new anthracotheriid artiodactyl from the Eocene Pondaung Formation of Myanmar. Vertebrata PalAsiatica 49: 85-113.

34 Pilgrim GE (1928) The Artiodactyla from the Eocene of Burma. Memoir of the Geological Survey of India Paleontologia Indica 13: 1-44.

35 Lihoreau F, Blondel C, Barry J, Brunet M (2004) A new species of the genus Microbunodon (Mammalia, Artiodactyla) from the Miocene of Pakistan: phylogenetic relationships and palaeobiogeography. Zool Scr 33:97-115.

36 Brunet M (1968) Découverte d'un crâne d'Anthracotheriidae, Microbunodon minimum (Cuvier), à la Milloque (Lot et Garonne). C R Acad Sci 267:835-838.

37 Schmidt M (1913) Ueber Paarhufer der fluviomarinen Schichten des Fajum. Geol Paläont Abh 11:155-263.

38 Black CA (1978) In Evolution of African Mammals, eds Maglio VJ, Cooke HBS (Harvard University Press, Cambridge), pp. 423-434.

39 Maclnnes DG (1951) Miocene Anthracotheriidae from East Africa. Fossil Mammals of Africa 4: 124.

40 Dineur H (1981) Le genre Brachyodus, anthracotheriidae (Artiodactyla, Mammalia) du Miocène inférieur d'Europe et d'Afrique. Unpublished PhD thesis, Université Paris 6.pp. 180.

41 Pickford M (1991) in The Geology of Libya vol. 4, eds Salem MJ, Hammuda OS, Eliagoubi BA (Elsevier, Amsterdam,), pp 1483-1490.

42 Hellmund M (1991) Revision der Europäischen species der Gattung Elomeryx Marsh 1894 (Anthracotheriidae, Artiodactyla, Mammalia)-Odontologishe Untersuchungen. Palaeontogr Abt A 220:1101.

43 Lihoreau F et al. (2009) First complete skulls of Elomeryx crispus (gervais, 1849) and of Protaceratherium albigense (Roman, 1912) from a new Oligocene locality near Moissac (sw France). $J$ Vertebr Paleontol 29(1): 242-253.

44 Geais G (1934) Le Brachyodus borbonicus des argiles de St. Henri (près Marseille). Trav Lab Géo. Fac Sci Lyon, Mém. 21:1-54.

45 Kostopoulos DS, Koufos GD, Christanis K (2012) On some anthracotheriid (Artiodactyla, Mammalia) remains from northern Greece: comments on the palaeozoogeography and phylogeny of Elomeryx. Swiss J Palaeontol 131(2): 303-315.

46 Pickford M (1987) Révision des suiformes (Artiodactyla, Mammalia) de Bugti (Pakistan). Ann Paléontol 73 : 289-350.

47 Lihoreau F et al. M (2007) Anatomical revision of the genus Merycopotamus (Artiodactyla ; Anthracotheriidae) : its significance on late Miocene mammal dispersions in Asia. Palaeontology 50:503524. 
Lihoreau et al. Supporting information

48 Black CC (1972) A new species of Merycopotamus (Artiodactyla: Anthracotheriidae) from the late Miocene of Tunisia. Notes du service de géologie de Tunisie 37: 5-39.

49 Pickford M (2006) Sexual and individual morphometric variation in Libycosaurus (Mammalia, Anthracotheriidae) from the Maghreb and Libya. Geobios 39:267-310.

50 Lihoreau F, et al. (2014) Description and palaeobiology of a new species of Libycosaurus (Cetartiodactyla, Anthracotheriidae) from the Late Miocene of Toros-Menalla, northern Chad. Journal of Systematic Palaeontology12 (7) 761-798

51 Pickford M (2008) Libycosaurus petrocchii Bonarelli, 1947, and Libycosaurus anisae $(37,1972)$ (Anthracotheriidae, Mammalia): nomenclatural and geochronological implications. Ann Paléont 94:39-55.

52 Lihoreau F, et al. (2006) Evidence for Late Miocene Chado-Libyan bioprovince: a new possible dispersal ability for early Chadian Hominids. Proc Natl Acad Sci USA 103:8763-8767.

53 Ginsburg L (1974) Les Tayassuidés des Phosphorites du Quercy. Palaeovertebrata 6:55-85.

54 Hellmund M (1992) Schweineartige (Suina, Artiodactyla, Mammalia) aus oligo-miozänen Fundstellen Deutschlands, der Schweiz und Frankreichs II. Revision von Palaeochoerus Pomel, 1847 und Propalaeochoerus Stehlin, 1899 (Tayassuidae). Stuttgarter Beitr Naturkde B 189:1-75.

55 Orliac MJ, Antoine P-O, Ducrocq S (2010) Phylogenetic relationships of the Suidae (Mammalia, Cetartiodactyla): new insights on the relationships within Suoidea. Zool Scr 39: 315-330.

56 Harris JM, Liu L-P (2007) in The Evolution of Artiodactyls, eds Prothero DR, Foss SE (The Johns Hopkins University Press, Baltimore), pp 130-150.

57 Brunet M, Sudre J (1987) Evolution et systématique du genre Lophiomeryx Pomel 1853 (Mammalia, artiodactyla). Münchner Geowiss Abh 10:225-241.

58 Colbert EH (1941) The osteology and relationships of Archaeomeryx an ancestral ruminant. American Museum Novitates 1135: 1-24.

59 Thewissen JGM, Russell DE, Gingerich PD, Hussain ST (1983) A new dichobunid artiodactyl (mammalia) from the Eocene of North-West Pakistan. Proceedings of the Koninklijk Nederlandse Akademie van Wetenschappen 86(2):153-180.

60 Theodor JM, Erfurt J, Métais G (2007) in The Evolution of Artiodactyls, eds Prothero DR, Foss SE (The Johns Hopkins University Press, Baltimore), pp 32-58.

61 Sudre J (1978) Les Artiodactyles de l'Éocène moyen et supérieur d'Europe occidentale (Systématique et évolution). Mém Trav. Instit. Montpellier Ecole Pratique des Hautes Etudes 7:1-229.

62. Coombs WP, Jr, Coombs MC (1977) The origin of anthracotheres. N Jb geol Pal Mh 10:584-599.

63. Coombs MC, Coombs WP, Jr (1977) Dentition of Gobiohyus and a reevaluation of the Helohyidae (Artiodactyla). J Mamm 58:291-308.

64. Ducrocq S, Chaimanee Y, Suteethorn V, Jaeger J-J (1997) First discovery of Helohyidae (Artiodactyla, Mammalia) in the Late Eocene of Thailand: a possible transitional form for Anthracotheriidae. C R Acad Sci 325:367-372. 
Lihoreau et al. Supporting information

65. Foss SE (2007) in The evolution of artiodactyls, eds Prothero DR, Foss SE (The Johns Hopkins University Press, Baltimore), pp 85-88.

66 Thewissen JGM, Gingerich PD, Russell DE (1987) Artiodactyla and Perissodactyla (mammalia) from the Early-Middle Eocene Kuldana Formation of Kohat (Pakistan). Cont Mus Paleont 27:247-274.

67 Kumar K, Sahni A (1985) Eocene mammals from the upper Subathu group, Kashmir Himalaya, India. J Vertebr Paleontol 5:153-168.

68 Thewissen JGM, Williams EM, Hussain ST (2001) Eocene Mammal Faunas from Northern IndoPakistan. J Vertebr Paleontol 10: 347-366

69 Orliac MJ, Ducrocq S (2012) Eocene raoellids (Mammalia, Cetartiodactyla) outside the Indian Subcontinent: palaeogeographical implications. Geol Mag 149:80-92.

70 Erfurt J, Métais G (2007) in The Evolution of Artiodactyls, eds Prothero DR, Foss SE (The Johns Hopkins University Press, Baltimore), pp 59-84.

71 Hooker JJ, Thomas KM (2001) A new species of Amphirhagatherium (Choeropotamidae, Artiodactyla, Mammalia) from the late Eocene Headon hill formation of southern England and phylogeny of endemic european anthracotherioids. Palaeontology 44: 827-853.

72 Hooker JJ, Weidmann M (2000) The Eocene mammal faunas of Mormont, Switzerland. Mémoires suisses de Paléontologie 120:1-141.

73 Sudre J (1974) D'importants restes de Diplobune minor (Filhol) à Itardies (Quercy). Palaeovertebrata 6(1-2) : 47-54

74 Brunet $M$ (1975). Les grands mammifères chefs de file de l'immigration oligocène et le problème de la limite Eocène-Oligocène en Europe. Unpublished Doctoral dissertation, Université de Poitiers. pp. 542

75 Stevens MS, Stevens JB (2007) in The evolution of artiodactyls, eds Prothero DR, Foss SE (The Johns Hopkins University Press, Baltimore), pp 157-168.

76 Geisler JH, Theodor JM, Uhen, MD, Foss SE (2007) in The Evolution of Artiodactyls, eds Prothero DR, Foss SE (The Johns Hopkins University Press, Baltimore), pp 19-31.

77 Boisserie, J.-R., Kiarie, C., Lihoreau, F. \& Nengo, I. (2017). Middle Miocene Kenyapotamus (Cetartiodactyla, Hippopotamidae) from Napudet, Turkana Basin, Kenya. Journal of Vertebrate Paleontology, 37(1), e1272055.

78 Lihoreau, F., Boisserie, J.-R., Manthi, F. K. \& Ducrocq, S. (2015). Hippos stem from the longest sequence of terrestrial cetartiodactyl evolution in Africa. Nature Communications, 6, 6264.

79 Boisserie, J. R., Suwa, G., Asfaw, B., Lihoreau, F., Bernor, R. L., Katoh, S., \& Beyene, Y. (2017). Basal hippopotamines from the upper Miocene of Chorora, Ethiopia. Journal of Vertebrate Paleontology, 37(3), e1297718.

80 Sileem, A. H., Sallam, H. M., Hewaidy, A. A., Gunnell, G. F., \& Miller, E. R. (2015).

Anthracotheres (Mammalia, Artiodactyla) from the upper-most horizon of the Jebel Qatrani Formation, latest early Oligocene, Fayum Depression, Egypt. Egyptian Journal of Paleontology, 15, 1-11. 
Lihoreau et al. Supporting information

81 Ducrocq, S., Coiffait, B., Coiffait, P. E., Mahboubi, M., \& Jaeger, J. J. (2001). The Miocene Anthracotheriidae (Artiodactyla, Mammalia) from the Nementcha, eastern Algeria. Neues Jahrbuch fur Geologie und Palaontologie-Monatshefte, (3), 145-156.

82 Lihoreau, F., Hautier, L., \& Mahboubi, M. (2014). The new Algerian locality of Bir el Ater 3: validity of Libycosaurus algeriensis (Mammalia, Hippopotamoidea) and the age of the Nementcha Formation.

Palaeovertebrata, 39, e1. 